University of Montana

ScholarWorks at University of Montana

Graduate Student Theses, Dissertations, \&

Professional Papers

1982

\title{
Experimentally determined impacts of a small suction gold dredge on a Montana stream
}

Virginia Gheen Thomas

The University of Montana

Follow this and additional works at: https://scholarworks.umt.edu/etd

Let us know how access to this document benefits you.

\section{Recommended Citation}

Thomas, Virginia Gheen, "Experimentally determined impacts of a small suction gold dredge on a Montana stream" (1982). Graduate Student Theses, Dissertations, \& Professional Papers. 2294. https://scholarworks.umt.edu/etd/2294

This Thesis is brought to you for free and open access by the Graduate School at ScholarWorks at University of Montana. It has been accepted for inclusion in Graduate Student Theses, Dissertations, \& Professional Papers by an authorized administrator of ScholarWorks at University of Montana. For more information, please contact scholarworks@mso.umt.edu. 


\section{COPYRIGHT ACT OF 1976}

THIS IS AN UNPUBLISHED MANUSCRIPT IN WHICH COPYRIGHT SUBSISTS, ANY FURTHER REPRINTING OF ITS CONTENTS MUST BE APPROVE BY THE AUTHOR,

Mansfield Library

UNIVERSITY OF MONTANA

DAte: 1988 

Experimentally Determined Impacts of a Small Suction
Gold Dredge on a Montana Stream.

By

\author{
Virginia Gheen Thomas \\ B.A.,University of Colorado ,1979. \\ Presented in partial fulfillment of \\ the requirments for the degree \\ of Master of Axts \\ seifiec \\ UNIVERSITY OF MONTANA \\ 1982
}

Approved by:

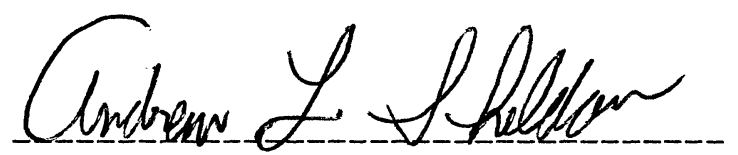

Chairman,Board of Examiners

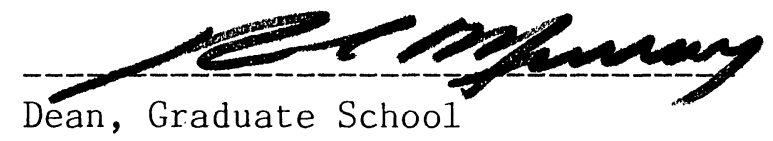

$5-19-83$

Date 
UMI Number: EP34717

All rights reserved

INFORMATION TO ALL USERS

The quality of this reproduction is dependent on the quality of the copy submitted.

In the unlikely event that the author did not send a complete manuscript and there are missing pages, these will be noted. Also, if material had to be removed, a note will indicate the deletion.

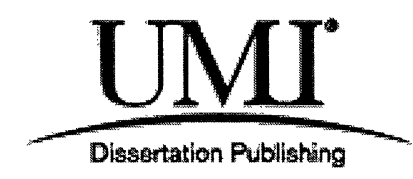

UMI EP34717

Copyright 2012 by ProQuest LLC.

All rights reserved. This edition of the work is protected against unauthorized copying under Title 17, United States Code.

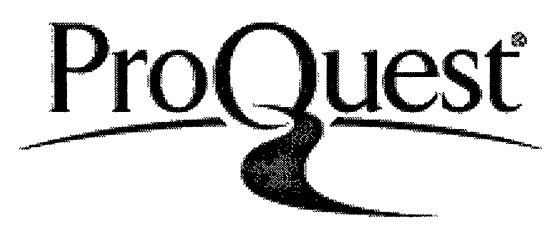

ProQuest LLC.

789 East Eisenhower Parkway

P.O. Box 1346

Ann Arbor, MI 48106 - 1346 
'I'homas, Virginia G., M.S., May, 1983 Wildlife Biology

The Experimentally Determined Impacts of a Smal1 Suction Dredge on a Montana Stream

Director:Andrew L. Sheldon

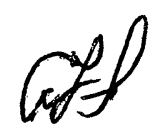

The use of small, portable, suction gold dredges has greatly increased since 1979, when the price of gold soared. A small suction dredge was operated on Gold Ck.,Missoula Co., Montana, to determine the effects on aquatic insects and stream bottom habitat. A section of stream ten meters long was dredged from bank to bank. Sampling was conducted before dredging and at upstream and downstream stations for control. The entire study was replicated at an upstream site. Significant $(\mathrm{P}<.01)$ change in aquatic insect abundance was restricted to the dredged area. Downstream areas were not affected $(P>.05)$. Recolonization was substantially complete one month after dredging. Intergravel permeability was not significantly $(P>.05)$ changed by dredging. Suspended sediment concentrations and turbidity during dredging were highly variable. Highest turbidity measured was $32 \mathrm{NTU}$ at the dredge outflow (upstream level 1.5 NTU ). Suspended sediment discharge was a maximum of $1019 \mathrm{mg} / 1$ at the outflow. Suspended sediment and turbidity returned to background levels within approximately $30 \mathrm{~m}$. Biological impacts of suction dredging appear to be highly localized. No immediate downstream impacts were recorded other than fine sediment deposition and deposition of unstable gravel beds. Those beds dispersed and were transferred downstream during the next year's peak flows, filling a downstream pool. 
My thanks to Dr. Raymond Murray and the University of Montana for providing financial support for this project. I am also indebted to Dennis Workman and Don Peters for lending me their field assistants and their trailer. Special thanks to Ron Spoon for cheerfully helping me in the field, even on Saturday. There are others who helped me in the field and lent me equipment. In particular I'd like to mention Jan Bonham, Chris Rudd, Bill Schultz, Dr. Andrew Sheldon, and Greg Munther. I would also like to thank Dr. Donald Loftsgaarden for his help with the statistical analysis. Finally, my husband Jed helped me with many of the more tedious chores required for this research. His support and assistance was invaluable. 
ABSTRACT $\ldots \ldots \ldots \ldots \ldots \ldots \ldots \ldots \ldots \ldots \ldots \ldots \ldots \ldots \ldots \ldots \ldots$

ACKNOWLEDGEMENTS .........................

LIST OF FIGURES.......................

LIST OF TABLES............................

CHAPTER

I. INTRODUCTION......................

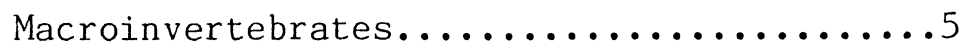

Fishes........................

II. MATERIALS AND METHODS..............9

The Study Site....................

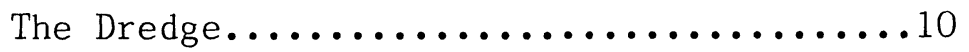

Macroinvertebrates................11

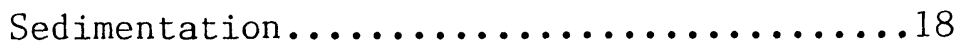

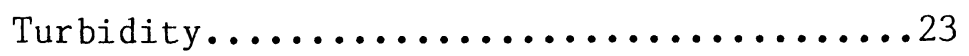

Gravel Permeability.................23

Channel Morphology.................25

III. RESULTS $\ldots \ldots \ldots \ldots \ldots \ldots \ldots \ldots \ldots \ldots \ldots \ldots \ldots \ldots \ldots \ldots \ldots$

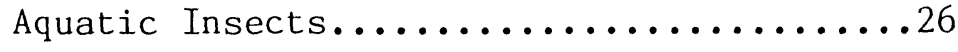

Suspended Sediment.................40

Deposited Sediment.................43

Turbidity ...................... 46

Channel Morphology................47 
Gravel Permeabilily.................49

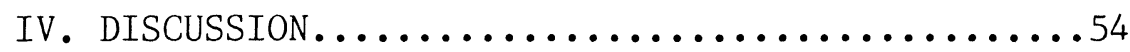

Laws and Regulations Governing Suction

Dredge Mining in the State of Montana....58

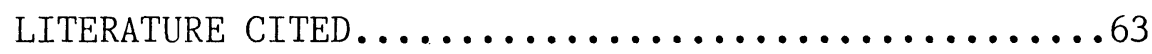

APPENDIX A

Administrative Rules of Montana - Water

Quality...........................67

APPENDIX B

Montana Dept of Fish, Wildlife, and Parks

Guidelines for Review Comments on Permit

Applications for Instream Mining............83

APPENDIX C

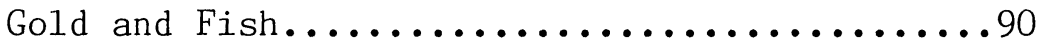


Figure

1. Relationship between the price of gold and the number of suction dredge permit applications received by the California Dept. of Fish and Game..................

2. Anatomy of a gold dredge................

3. Aquatic insect sampling design............12

4. Mean-Variance relationship before logarithmic

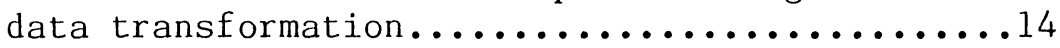

5. Mean-variance relationship after logarithmic

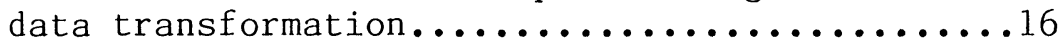

6. Suspended sediment sampling design..........20

7. Deposited sediment sampling design..........22

8. Changes in aquatic insect abundance over time...28

9. Changes in insect abundance over time, by order.35

10. Suspended sediment concentration downstream

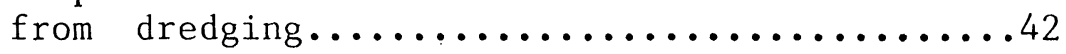

11. Deposited sediment before and after dredging...44

12. " " " " " " " " " " " " " " "

13. Gold dredge during dredge operations.........48

14. Gold dredge operations after dredging........50

15. Site A one year after dredging.............51

16. Changes in intergravel permeability.........5 52 


\section{LIS'I' OF' 'I'ABLL'S'}

Table

1. Three way analysis of variance.............27

2. Analysis of variance by taxonomic group........30

3. Recolonization analysis of variance..........33 


\section{INTRODUCTION}

The purpose of this research was to determine the impact of suction dredging for gold on the biological and physical characteristics of streams. Suction gold dredges have been in use on western rivers since the 1930's. However, today's dredges are different in that they are smaller, easily portable, and commercially manufactured. The availability of inexpensive, lightweight dredges, combined with recent high gold prices, has resulted in a great increase in suction gold dredge activity (Figure 1).

The effects that these dredges have on the stream environment are largely unknown. The few studies done on dredging operations, particularly in the 1950's, produced alarming results. Studies done in California found chinook salmon (Oncorhynchus tschawytcha) avoided silted areas downstream from mining and concentrated their redds in a clear tributary, resulting in overlapping redds and increased egg mortality. Silted areas also contained 41 to 63 percent fewer aquatic invertebrates than unsilted areas(Sumner and Smith, 1939). Later studies found high mortalities of salmonid fishes and macroinvertebrates downstream from suction gold dredges (Campbel1,1953;Campbel1, 1954;Casey,1959). 


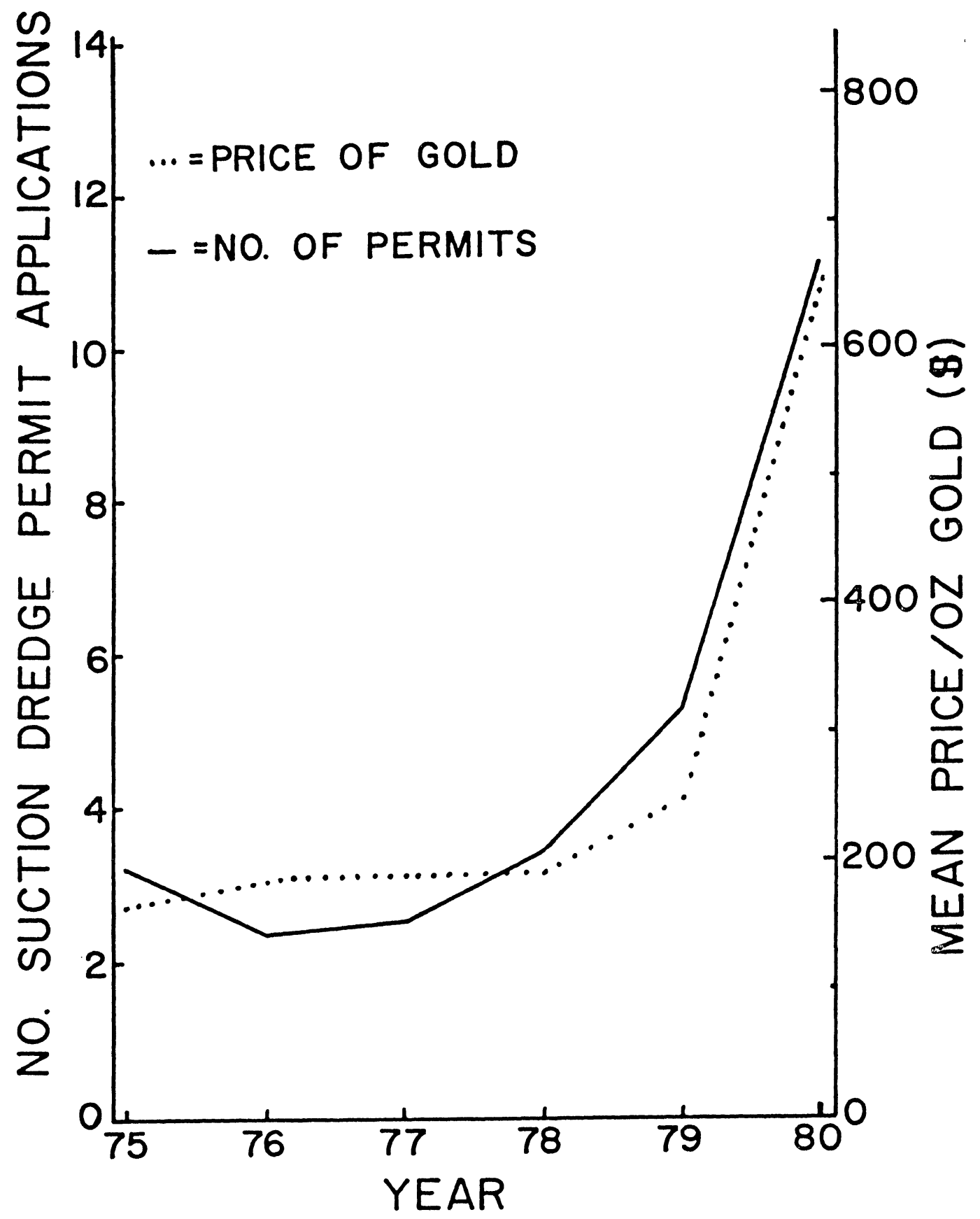

FIGURE 1. Relationship between the mean price of gold and the number of suction dredge permit applications received by the California Department of Fish and Game. Permit numbers (X 1000). Source: Harvey, et.al.,1982. 
These studies dealt with fairly large scale operations utilizing heavy equipment. What impact does a small (2.5 1

inch,6.4 $\mathrm{cm}$. ) portable suction dredge have on a Montana stream?

Gold dredges operate by sucking the bottom gravels into a baffle box in which the current is reversed and turbulence increased. Flow then continues past or through a classifier screen, then out through the sluice box and into the river (Figure 2). The heavier materials settle on the bottom, while lighter fines are carried downstream, where they are redeposited.

There are two primary areas of concern. One is the downstream impacts due to the redeposition of fines and increased turbidity. The other is the area actually dredged. Unconsolidated material, including any buried fish eggs and all aquatic invertebrates, are picked up from the bottom and entrained through the dredge. Bottom materials are rearranged and channel morphology could be changed to an unstable form. In addition, periphyton growth is removed from the area dredged.

1 Samples were, whenever possible, taken in metric units. However, many hydrologic parameters are still commonly given in English units. To avoid confusion, all measurements in this paper are given in English and metric units. 


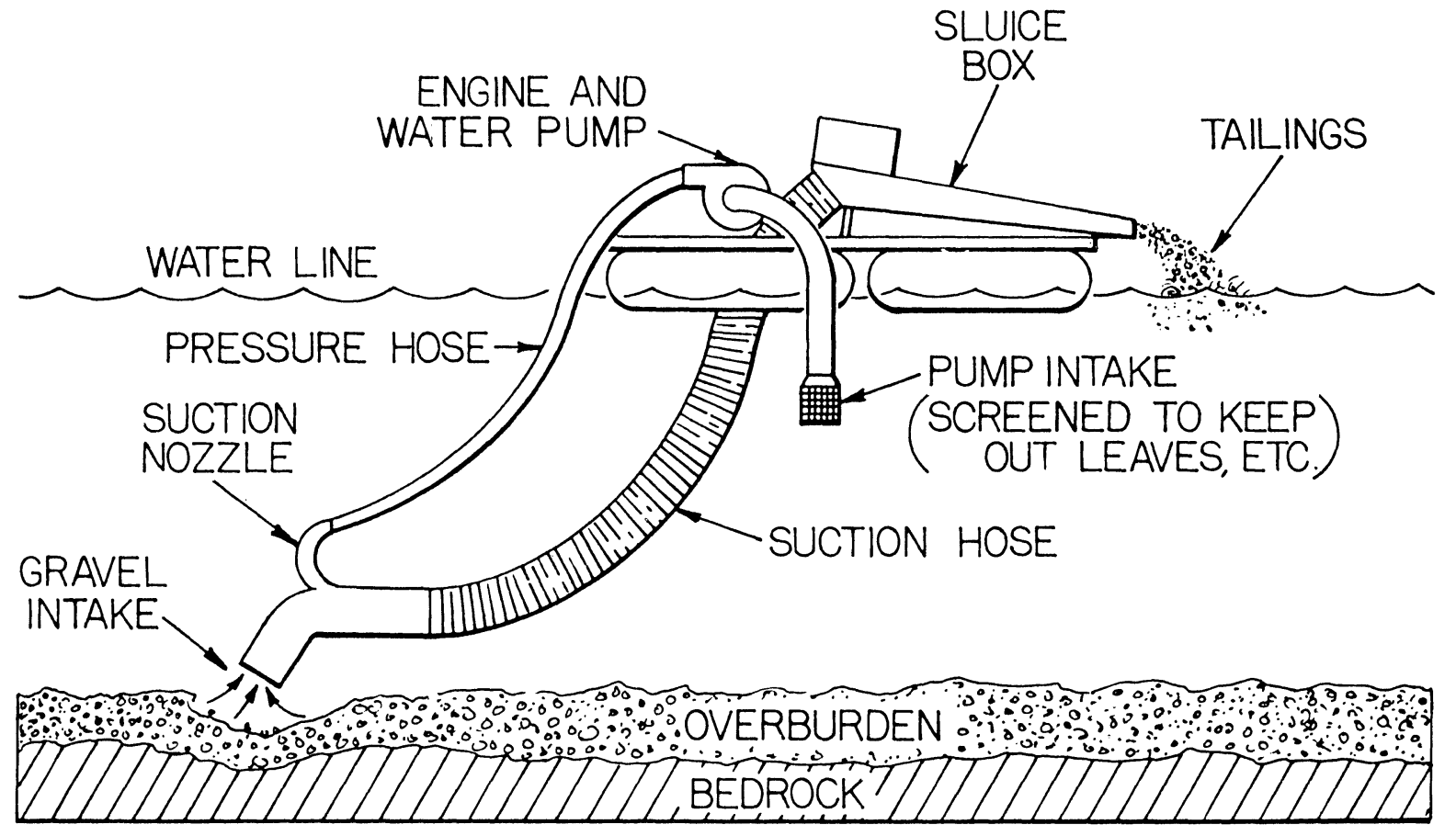

FIGURE 2. Anatomy of a suction gold dredge. Sourcc:Thornton, (1979). 
The purpose of this study was to determine the effects a 2.5 inch $(6.4 \mathrm{~cm})$ suction gold dredge has on aquatic insects and stream bottom habitat in a small Montana stream. It is hoped that the data will be of use to water resource managers who are in need of sound scientific data on which to base their management decisions. In addition, the laws and regulations governing suction dredging were analyzed and reviewed.

\section{MACROINVERTEBRATES}

Aquatic invertebrates are a major component of the aquatic food web. A large scale, long term decrease in invertebrate populations would have far reaching implications, including a decrease in fish productivity. The distribution of benthic insects inhabiting lotic environments is highly dependent on substrate particle size (Cummins and Lauf,1969). Changing the substrate by adding sediments could change the macroinvertebrate diversity and density. McClelland and Brusven (1980) found that increased quantities of sediment in laboratory streams filled substrate interstices and reduced the "effective" size of surface cobbles reducing insect density in the test region. Ambuhl (1959) and others have shown that regions of zero velocity exist at rock-water interfaces and in spaces downstream from and beneath rocks. Many insects utilize these areas when foraging. Bournaud (1963) reported that without these low velocity areas, many insects, even dorsoventrally flattened species, could not 
maintain their position in the current. Increased quantities of fine sediments effectively eliminate many of these critical static water areas around cobbles and boulders (McClelland and Brusven, 1980). Fine sediments around cobbles produce a "gasket effect" by creating a seal, thereby restricting access to the undersurface of the cobbles or deep sediment except to specialized, burrowing forms (Brusven and Prather, 1974). In addition, many common riffle insects are unable to move upstream on sand substrates. Pebble and cobble may be necessary for upstream movement by most insects even at low water velocities (Luedtke and Brusven, 1976).

Suspended particles may also be an important factor as they may abrade respiratory surfaces or dislodge insects and vegetation. Chutter (1969) found that sediment related changes in the invertebrate faunas of two South African rivers occured without the benthos being smothered with inorganic debris. Many workers (Nuttall and Bielby,1973; Bjornn et.a1.,1975; Cordone and Pennoyer,1960 and others) have noted decreased aquatic insect populations below silt outflows.

Is the amount of sediment produced by a 2.5 inch $(6.4 \mathrm{~cm})$ suction dredge enough to negatively impact downstream insect populations? If so, how far downstream are populations affected? What is the duration of impact? What are the direct impacts of dredging? These are the questions this section of the study addressed. 
FISHES

Sedimentation on the stream substrate, particularly the gravel used for fish spawning, produces significant detrimental effects on the salmonid resources. Sediments have the potential to affect fishes by: 1)clogging and abrading gills and other respiratory surfaces, 2)adhering to the chorion of eggs, 3)providing conditions conducive to the entry and persistence of disease related organisms, 4)inducing behavioral change, 5)entombing different life stages 6)altering water chemistry by the adsorption of chemicals, 7) affecting utilizable habitat by scouring and filling of pools and riffles and changing bedload composition, 8) reducing photosynthesis and primary production, 9) affecting intragravel permeability and dissolved oxygen levels which effect the egg and embryo stages of salmonids which develop within the gravel and, 10)affecting the fishing for and the catchability of sport fishes (Iwamoto, et.al., 1978).

Excessive deposition of sediment in streams results in a decrease in depth and an increase in width. Velocity decreases and the characteristic riffle-pool relationship is altered, decreasing the number and depth of pools (Rulifson,1979). Deep pools are extremely important to stream fishes. Sheldon (1968) found that the number of species of fish was most strongly correlated with stream depth. His work is supported by Inger and Chin (1963) who 
found that Bornean fishes showed considerable specialization for feeding at particular depths. Large scale filling of pools could be expected to reduce the number of species of fish living in a stream.

For these reasons it is important to quantify the amount of sediment produced by small dredges and determine where it is deposited and how long it remains.

Dredging operations which cut into banks and destroy bankside vegetation are particularly damaging. When bankside vegetation is removed banks may become unstable, resulting in increased bank erosion and increased stream sedimentation. In addition, undercut banks and overhanging vegetation provide cover for fishes. Boussu (1954) found that when undercut banks and overhanging brush were removed from a stream, trout populatons, especially the larger fish, were adversely affected. Warner and Porter (1960) stated that the removal of bank vegetation, overhanging banks, and other shelter destroyed some of Maine's finest trout streams. Gunderson (1968) found that the weight/acre of brown trout (Salmo trutta) was $31 \%$ greater in an ungrazed section of stream than in a grazed section. He attributed the difference to there being a narrower, deeper channel system, more favorable composition and distribution of water types, and more cover in the ungrazed section because the riparian vegetation had been preserved. 
MATLRIALS $\Lambda$ NI) MEIIIOISS

THE STUDY SITE

The study was conducted on Gold Creek, Missoula County, Montana ( $15 \mathrm{~N}, \mathrm{R} 17 \mathrm{~W}$, sec 36) in July through September, 1980. Gold Creek is a relatively undisturbed, high gradient (average drop $120 \mathrm{feet} / \mathrm{mile}(22.72 \mathrm{~m} / \mathrm{km})$ ), third order stream. Typical late summer flows are about 15 cubic feet 3

per $\operatorname{second}(.42 \mathrm{~m} / \mathrm{sec})$. No previous mining has taken place in the drainage. Most of the lower drainage basin is owned by the Champion International Corporation, and is managed as a tree farm. The upper portion of the drainage is managed by the U.S. Forest Service and has been in an undeveloped state until recently, when some large timber contracts were let for the area. There are no grazing permits let for Gold Ck., however stray cattle do occasionally wander in from adjacent drainages. Despite extensive clearcutting in the drainage, the riparian zones have been left fairly intact and the stream does not suffer from turbidity and sedimentation problems.

Rock types in the Gold Creek drainage include Precambrian Belt Supergroup sediments, principally Missoula and Wallace formations. The study site is covered by Tertiary alluvial gravel fill. The gravels are probably several hundred feet thick, although no definitive estimate has been made. No gold has yet been found in the stream gravels (J.Thomas, pers.comm.,1982). The streambed is composed of 
gravel, cobbles and boulders with some sand and silt. Gold Creek supports a good population of cutthroat trout(Salmo

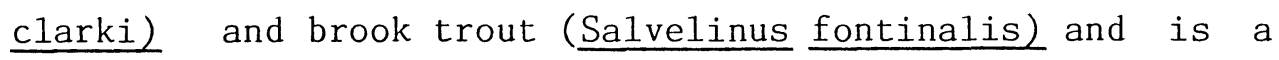
bull trout (Salvelinus confluentus) spawning stream • Gold Creek was chosen as a study site because of its pristine condition and bottom composition.

THE DREDGE

The dredge,manufactured by Keene Engineering, had a 2.5 inch $(6.4 \mathrm{~cm})$ diameter nozzle and was powered by a 2 horsepower Briggs and Stratton engine. It is one of the most popular size dredges used by weekend gold dredgers. STUDY DESIGN

A section of stream 50 meters long was chosen for its relatively uniform character. The site was divided into five 10 meter segments. The upstream most section (section 1) was maintained as a control. The next 10 meters, (section 2), was dredged from bank to bank and to the greatest depth possible $(<1 \mathrm{~m}$.) The lower three sections (sections 3,4 and 5) were studied to determine downstream impacts. An impact study is best designed when it judges impact effects against previously collected baseline data (Green,1979). For this reason, all parameters were measured before dredging took place. The entire study was replicated at a second site (site B) upstream of the first site (site A). 


\section{MACROINVERTEBRATES}

Six random samples were taken in each of the five study sections before and after dredging (Figure 3). Randomization was accomplished using a table of random numbers to locate sample sites. Samples were taken with a homemade Hess- type sampler (area $78.5 \mathrm{in}^{2} .05 \mathrm{~m}$ ) and preserved in the field in $70 \%$ ethanol. In the lab a solution of rose bengal stain was added to the samples to facilitate sorting the benthic invertebrates. Rose bengal selectively stains chitin pink while the other debris in the sample retains its natural color (Mason and Yevich, 1967). Samples were sorted to the lowest taxonomic level feasible, usually to genus.

Samples were taken before and immediately after dredging took place. Dredging took approximately two weeks to complete at each site. Griffith and Andrews (1981) found recolonization of dredged plots was substantially complete in 38 days so a complete set of macroinvertebrate samples were taken one month after dredging to determine the degree of recolonization.

Analysis of variance was used to determine the location and magnitude of dredging impacts. In standard analysis of variance the model specifies a number of assumptons which should be tested before proceeding with the analysis. Minor failures in the assumptions do not greatly disturb the conclusions drawn from the standard analysis. Some of the serious failures, if detected, can be treated after the data is collected (Snedecor and Cochran,1980). One of the key 
SAMPLING DESIGN

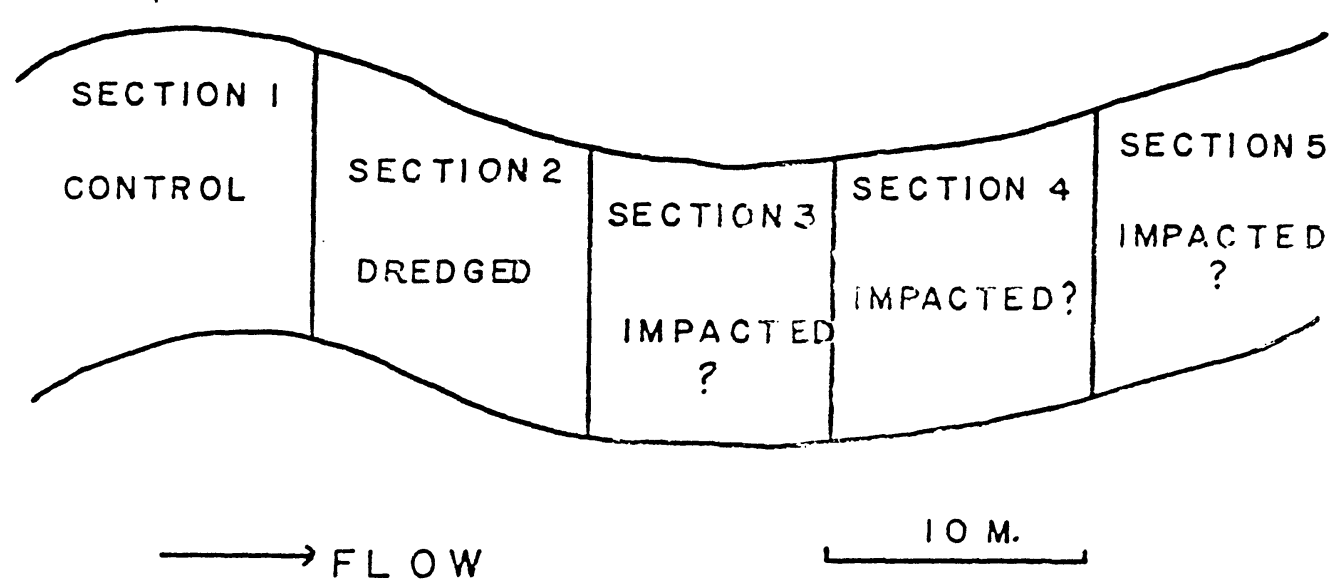

6 SAMPLES PER SECTION

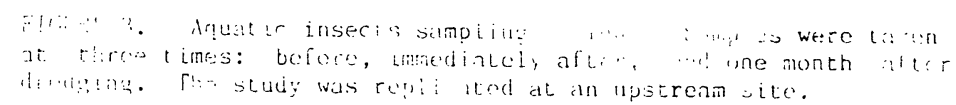


assumptions frequently violated in this type of data is the assumption of independent variances. Often in sampling natural populations, the animals are clumped, rather than normally distributed. The result is that the sample variance is not independent of the sample mean. The simplest test for this violation is a plot of means versus variance. As Figure 4 shows, as the mean number of benthic invertebrates increases, the variance of the counts tends to increase as well. A simple statistical test, the F-max test (Sokal and Rohlf, 1980) can be used to confirm the graphical interpretation. The F-max test is simply the ratio of the largest to the smallest sample variances.

$$
\mathrm{F}-\max \text {, site one }=\frac{\mathrm{s} 2}{\mathrm{~s} 2} \frac{\max }{\min }=\frac{265,905}{72}=3693.1 \quad \mathrm{P}(<.01)
$$

Therefore, it is necessary to reject Ho: ${ }^{2} \neq f(u)$.

Heterogeneity of variance can be cured by using a data transformation. The choice of a specific transformation is based on the mean-variance relationship, which in turn is a function of the spatial relationship. Many field distributions of organisms are highly aggregated (o $>u$ ) and approach the logarithmic series. In practice, most data from samples of field distributions of organisms may be transformed as $z=\log (x+1)$, which allows values of zero to be used (Green,1979). This transformation was applied to 


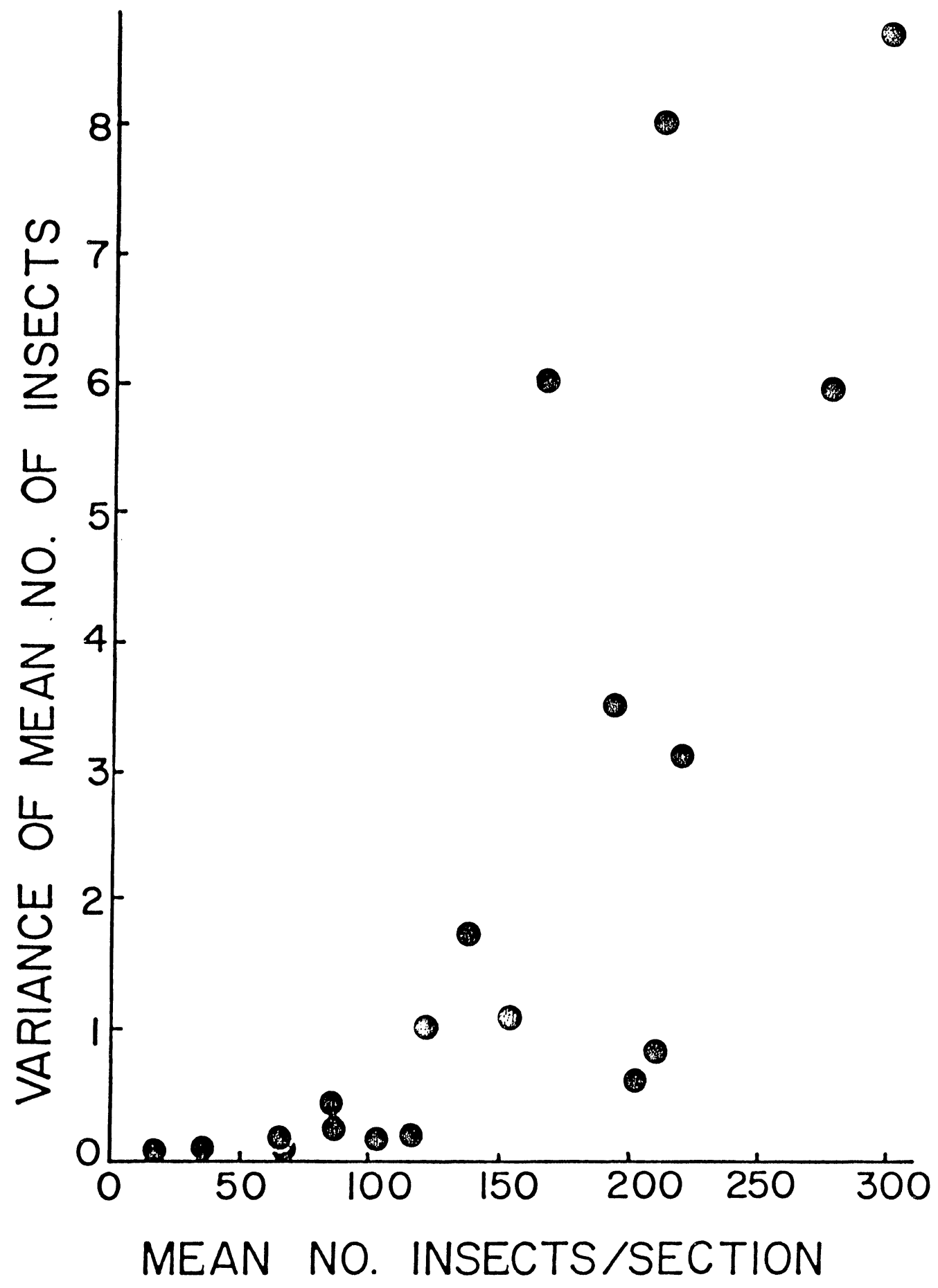

FIGURE 4. Mean - Variance relationship before logarithmic data transformation. Variance (X 10,000). 
the counts of aquatic insects before statistical analysis was attempted. Figure 5 confirms that the variance is no longer a function of the mean after data transformation. The $F$ max test also confirms this

$$
\text { Fmax, site } 2=\frac{.85}{.02}=42.5 \quad \mathrm{P}(>.01)
$$

A 2 X 2 X 5 (site $X$ treatment $X$ section) analysis of variance (ANOVA) was performed on the transformed data using SPSS subprogram ANOVA (Nie,et.a1.,1975). One purpose of this analysis was to determine whether dredging effected both sites in the same way. If so, these findings may be applicable to similar streams treated in similar ways. If the results are similar at both sites the three way interaction term (treatment $X$ site $X$ section) should not be significant. The treatment main effect term is not necessarily indicative of dredging impacts. There was a two week time lag between the before and after samples and significant natural changes in insect abundance could have taken place over that time. There are two periods during the life history of aquatic invertebrates when they are not vulnerable to benthos sampling; adulthood and egg and early instar stage. If large numbers of insects are moving into or out of these phases during the dredging period it would appear as an increase or decrease in the mean numbers of insects over time. Assuming that natural changes in invertebrate density 


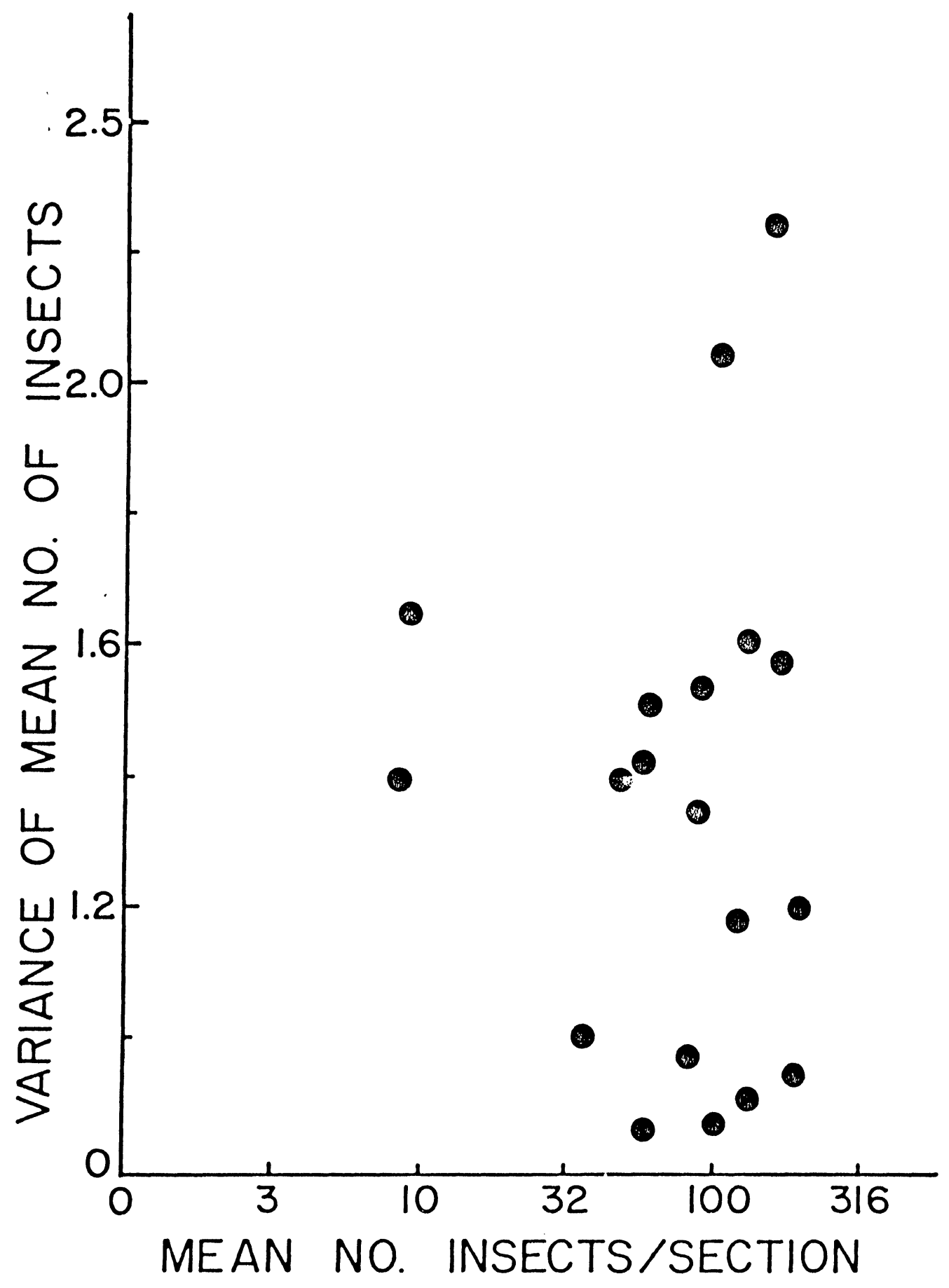

FIGURE 5. Mean - Variance relationship after logarithmic data transformation. ( $Y=\log X+1)$. 
will occur at an equal rate throughout the stream, then dredging effects can be tested by examining the section $\mathrm{X}$ treatment interaction. If significant it would indicate that the density of insects in one or more sections changed relative to the density in other sections.

Although this sampling design produced satisfactory results in this case, this design would not be universally applicable. It is not a balanced design since every section received a different treatment. Consequently, the treatment effects are confounded with time effects. A balanced design would have a control section for each treatment section.

The two way treatment $X$ section interaction was significant but because of the confounding problem, further analysis was necessary to prove dredge impacts. A oneway ANOVA was conducted on the before and after transformed data using SPSS subprogram ONEWAY (Nie, et.a1., 1975) to determine which sections were behaving differently. Each site was treated separately. The purpose of these ANOVAs was to determine if the mean number of benthic insects was the same in all sections before dredging and if the means were the same in all sections after dredging. Scheffe's test(Snedecor and Cochran,1980) was computed using SPSS to pick out those sections which were significantly different.

Each taxonomic group was then analyzed separately. Oneway ANOVAs were conducted on each of the common taxonomic groups. Rare genera were ignored because it was not 
possible to detect any change in their abundance. This portion of the analysis was designed to detect changes in species composition due to suction dredging.

A oneway ANOVA was conducted on the samples taken one month after dredging in sections one, two, and three. ANOVAs were conducted on the total counts and at the ordinal level. These samples were not sorted below the ordinal leve1.

A two way (section $X$ time) ANOVA compared one-day-after dredging to one- month-after-dredging samples. A significant interaction term would indicate that either the dredged area or the downstream area was behaving differently over time than the control section.

\section{SEDIMENTATION}

Suspended sediment was measured with a depth integrating sediment sampler, the $\mathrm{DH}-48$. A depth integrating sediment sampler is designed to accumulate a water sample from a stream vertical at such a rate that the velocity in the nozzle at the point of intake is always as nearly as possible, identical with the mean stream velocity while running the vertical at uniform speed (Guy,1970). Samples of sediment concentration obtained by integration with the flow 
can then be used with the flow rate in the given cross section to compute the sediment discharge where:

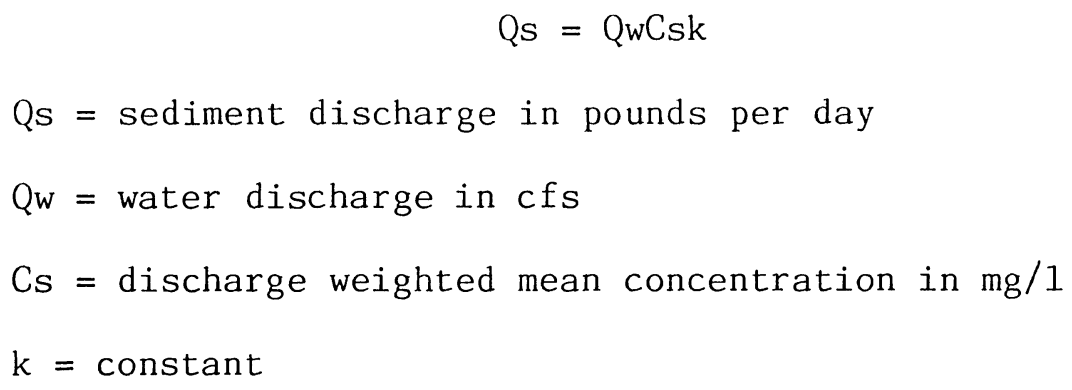

One sample was taken above the dredge outflow for a control. Directly below the dredge outflow three samples were taken one foot $(.3 \mathrm{~m})$ apart. Three more samples were taken five feet below the outflow, two feet $(.6 \mathrm{~m})$ apart. Four samples were taken, representing the entire streamflow, twentyfive feet $(7.6 \mathrm{~m})$ below the outflow (Figure 6). The object of this sampling design was to map out the plume of suspended sediment. At the point of the outflow the sediment is concentrated in a narrow band. As it flows downstream, it disperses and covers a wider area. The amount of sediment discharged at any moment through a suction dredge is highly variable depending on the type of bottom materials being dredged. Suspended sediment samples were taken when the discharge appeared to be the most murky in order to determine the worst case situation. Sediment samples were filtered (through Whatman \#41 filter paper) and the residue was dried for one hour at $100 \mathrm{C}$ and then 


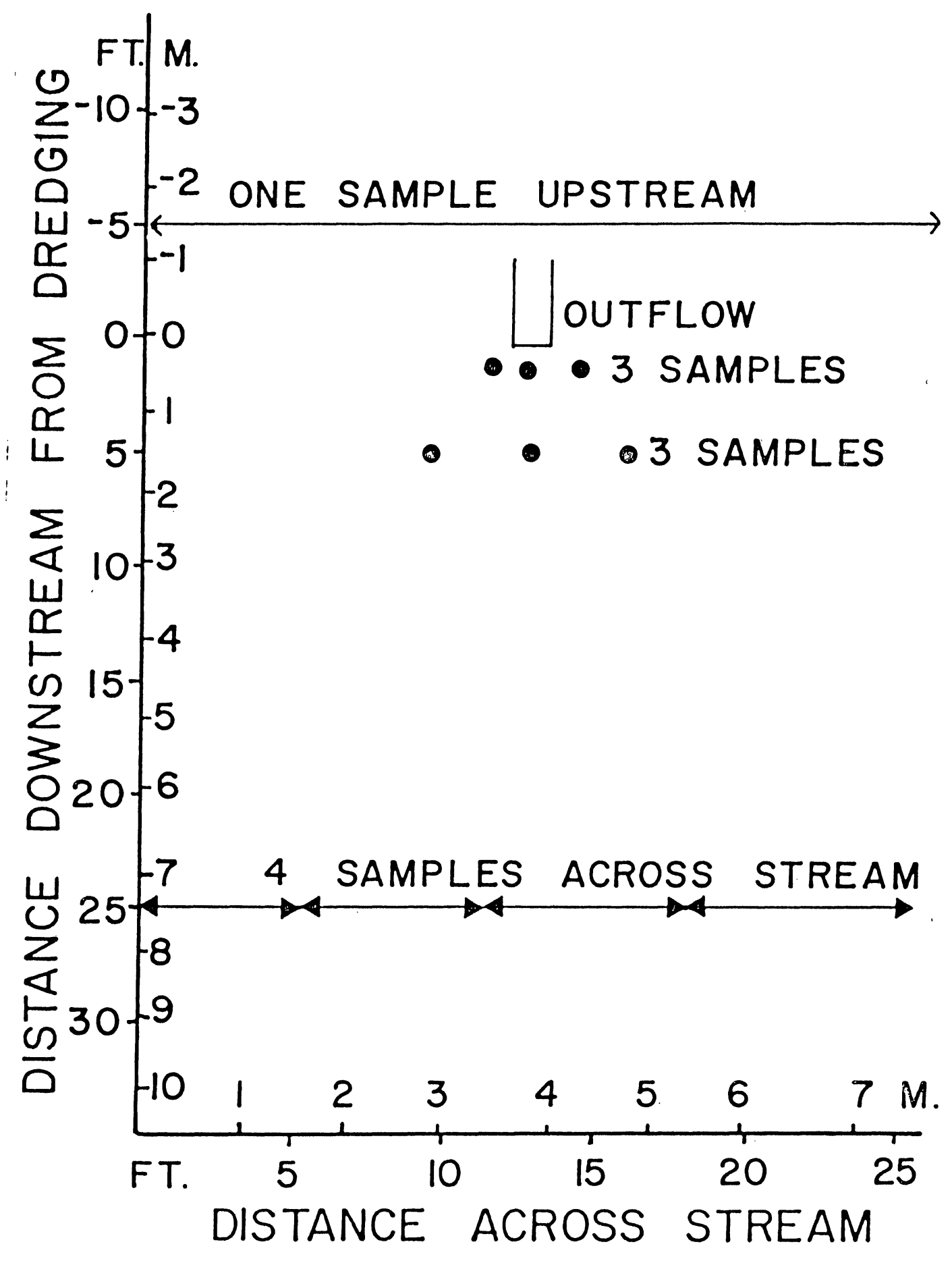

FIGURE 6. Suspended sediment sampling scheme. 
weighed. Current velocity and discharge were measured on the same days that suspended sediment samples were taken using a pygmy current meter.

Deposited sediment was measured using a trap similar to that of Welton and Ladle (1979). The trap is made of aluminum beverage cans with the tops cut off. The cans were fitted with nylon rope handles and were placed inside 3 inch diameter PVC pipes which were cut to fit the cans. The cans were filled with washed gravel (gravel too large to go through a size 5 Tyler standard screen $(3.962 \mathrm{~mm}$ opening). The trap was buried in the stream bottom so the top of the trap was as close to flush with the stream bottom as possible. The PVC pipe facilitates removal and replacement of the trap in the stream bed.

Five sediment traps were equally spaced across the middle of the control section, and the second and third downstream sections. The dredged section did not have any traps since it was to be dredged, but the first downstream section had a row across the top of the section and one across the middle (Figure 7).

Traps were left in place for five days before dredging began. The gravel was then rewashed, the wash water (containing sediments finer than $3.963 \mathrm{~mm}$ ) was saved for analysis, and the traps replaced in the stream. The same proceedure was followed after dredging. The wash water was filtered through Whatman \#41 filter papers, dried, and weighed. The same proceedure was followed after dredging. 


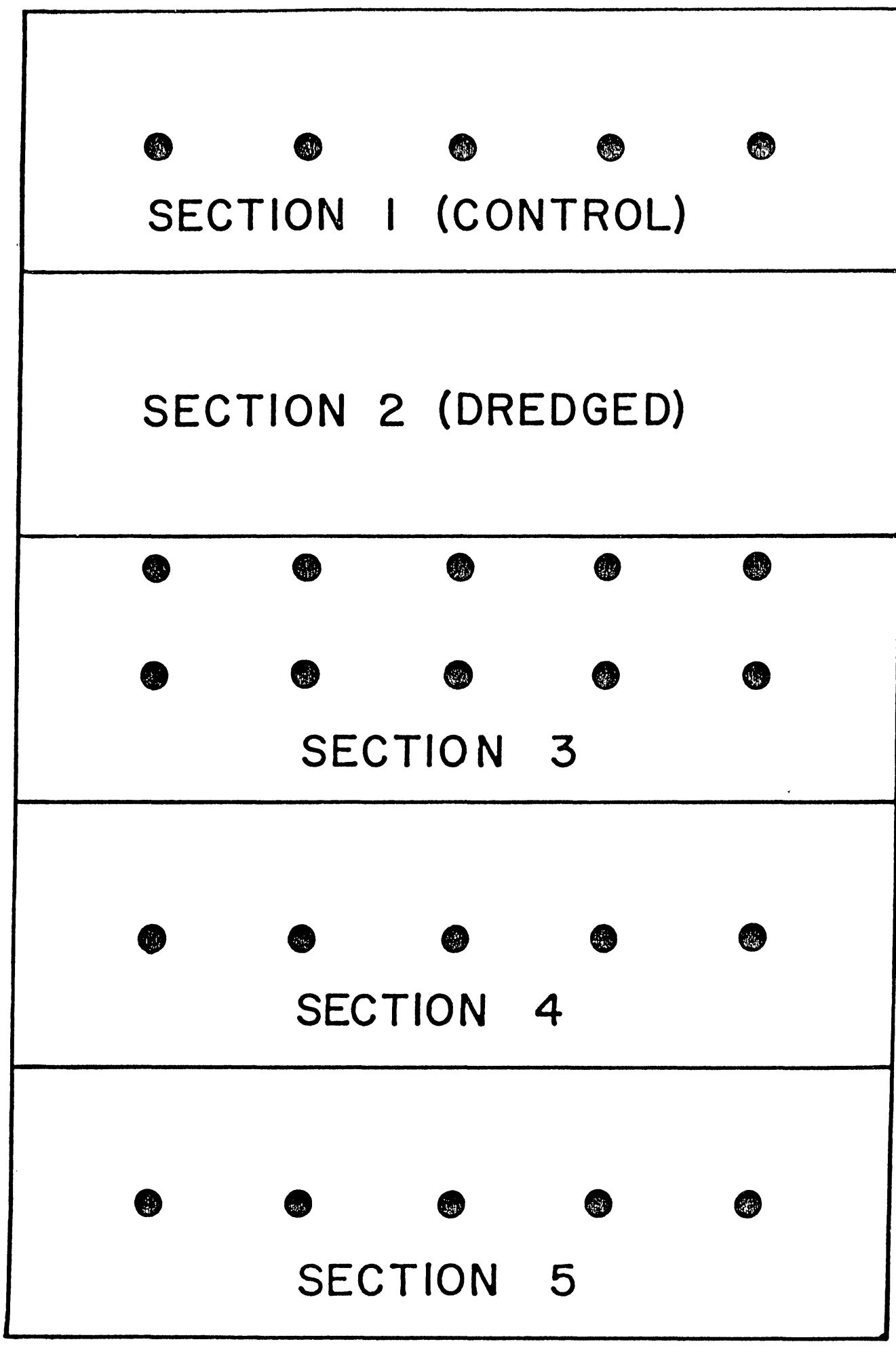

- = BURIED SEDIMENT TRAP

FIGURE 7. Deposited sediment sampling scheme. 
A curve was fitted to the deposited sediment data using BMDP derivative free non-linear regression (Dixon, 1981). This program uses iteration to find the parameters which solve the problem with the smallest residual sum of squares. TURBIDITY

Turbidity was measured during dredging upstream and downstream of the dredge. Samples were taken using a DH-48 depth integrating sediment sampler. One sample was taken upstream of the operating dredge, and four were taken $25 \mathrm{ft}$ downstream. Each of the four samples represented approximately $6 \mathrm{ft}$ of the stream's width. Samples were taken when the dredge appeared to be discharging a maximum amount of fine material. Turbidity was determined using a Hach 2100A turbidimeter.

Turbidity measurements are usually used as an index to the quantity of suspended sediment. However, the percentage contribution of settleable solids to turbidity is highly variable. The varying size, shape, specific gravity, and refractive index of sediment in suspension in a stream result in varying correlations between turbidity and suspended sediment (Duchrow and Everhart, 1971). In this study, suspended sediment was measured directly. The primary purpose of taking turbidity measurements was to fulfill the requirements of the Montana stream discharge permit.

GRAVEL PERMEABILITY

Developing salmonid eggs and fry need flowing water to 
carry away metabolic wastes and to supply them with oxygen (Meehan and Swanson,1977). Reduction in water velocity and dissolved oxygen concentration each result in a longer development period to hatching, smaller embryos,higher prehatching and posthatching mortality, and increased occurance of stucturally abnormal embryos (Silver and Douderoff, 1963). Therefore, high gravel permeability is important to successful salmomid spawning.

Intergravel permeability, at the velocities usually found in stream gravels, is a function of water viscosity and, especially, the composition and degree of packing of the gravel (Pollard,1955). Therefore a layer of fine sediment on the stream bottom gravels can reduce intergravel permeability

Does suction dredging change downstream intergravel permeability? Is there a significant change in the permeability of the area dredged?

Mark VI groundwater standpipes were used to measure intergravel water permeability and dissolved oxygen by the technique described by Terhune (1955). The Mark VI groundwater standpipe consists of a 36 inch length of $11 / 4$ inch diameter aluminum standard pipe with a steel point. Fortyeight $1 / 8$ inch diameter holes, evenly spaced above the steel point, allow water to flow into the standpipe. $\Lambda$ heavy sledgehammer was used to drive the standpipes 10 inches (.25 m) into the stream. Three standpipes were driven into each of the five sampling locations at each of the study sites. 
Water in the pipe is lowered a fixed amount ( 1 inch) and the resulting inflow rate is measured by pumping water out of the pipe, maintaining the one inch head. Inflow is measured in $\mathrm{ml} / \mathrm{sec}$ which is converted to permeability in $\mathrm{cm} / \mathrm{hr}$ using a calibration curve (Terhune,1958).

Intergravel dissolved oxygen was measured either by dropping the probe of a dissolved oxygen meter into the pipe or by withdrawing water with the pump and conducting Winkler titrations on the water. Permeability and dissolved oxygen were measured before and after dredging at both sites.

CHANNEL MORPHOLOGY

Channel morphology was mapped using a Keuffel and Esser transit. One cross section was mapped across the middle of each section at the first study site. The cross sections were mapped before and after dredging took place. At the second study site, more extensive mapping was done. Five cross sections were mapped in the control section and the dredge section. In addition, three longitudinal lines were mapped from the top of the section 1 to the bottom of section 2. The downstream sections; sections 3,4, and 5, were not mapped at site B. Photos were taken of both study sites before and after dredging took place to document any changes. 


\section{AQUATIC INSECTS}

What immediate impact does dredging have on aquatic insect abundance and where do the impacts occur? A three way (site $X$ treatment $X$ section) factoral analysis of variance (ANOVA) conducted on log transformed data showed no significant three way interactions $\mathrm{P}(F=.12$ ) (Table 1 ). The treatment effects found at site $A$ are of the same degree in the same section as the effects at site $B$. The replication (study site B) substantiates the results from study site A. The treatment by section interaction was significant $\mathrm{P}(\mathrm{F}<.0005)($ Table 1$)$. This indicates that dredging has an impact on at least one section. A plot of the mean number of insects found in each section show that, in section 2, the dredged section, mean insect abundance greatly decreased after dredging (Figure 8 ). Downstream insect abundance does not appear to be altered.

ANOVAs were conducted on the before treatment and after treatment data. Each site was considered separately. At both sites, the mean number of aquatic insects was the same in al1 five sections before dredging began $(\mathrm{P}>.05)$. After dredging, both sites showed a significant $P(F<.01)$ difference between sections. Scheffe's lest was used to determine the sections with significantly different means. At both sites, section two contained significantly fewer 
TABLE 1

Three way Time X Section X Site ANOVA

\begin{tabular}{|c|c|c|c|c|c|}
\hline $\begin{array}{l}\text { Source of } \\
\text { variation }\end{array}$ & $\begin{array}{l}\text { Sum of } \\
\text { squares }\end{array}$ & $d f$ & Mean square & $\mathrm{F}$ & $P(F)$ \\
\hline Main effects & 8.78 & 6 & 1.46 & 8.39 & .00 \\
\hline SITE & 1.55 & 1 & 1.55 & 8.92 & .00 \\
\hline DAY & 1.23 & 1 & 1.23 & 7.06 & .01 \\
\hline SECTION & 5.84 & 4 & 1.46 & 8.38 & .00 \\
\hline 2-Way & & & & & \\
\hline Interactions & 6.66 & 9 & .74 & 4.24 & .00 \\
\hline SITE X DAY & .51 & 1 & .51 & 2.96 & .09 \\
\hline $\begin{array}{l}\text { SITE X } \\
\text { SECTION }\end{array}$ & 1.15 & 4 & .28 & 1.65 & .17 \\
\hline $\begin{array}{l}\text { DAY X } \\
\text { SECTION }\end{array}$ & 4.82 & 4 & 1.20 & 6.91 & .00 \\
\hline $\begin{array}{l}3 \text { Way } \\
\text { Interactions }\end{array}$ & & & & & \\
\hline $\begin{array}{l}\text { DAY X SITE X } \\
\text { SECTION }\end{array}$ & 1.31 & 4 & .32 & 1.87 & .12 \\
\hline Explained & 16.75 & 19 & .88 & 5.05 & .00 \\
\hline Residual & 16.38 & 94 & .17 & & \\
\hline Total & 33.14 & 113 & .29 & & \\
\hline
\end{tabular}



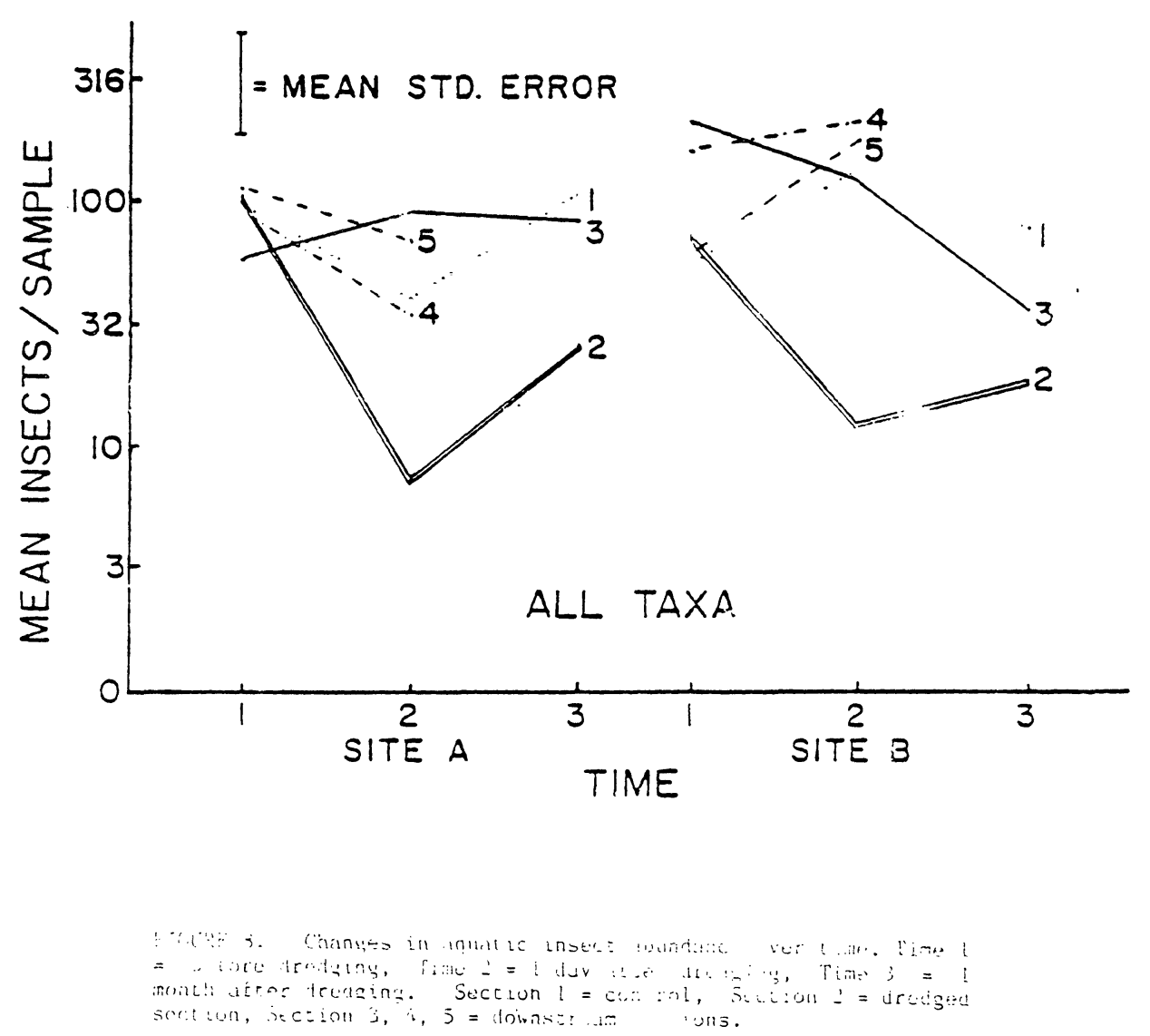
insects than the control section or the three downstream sections. No change in downstream insect abundance could be detected,relative to the control section. The data show that the immediate impacts of dredging on aquatic insect abundance is limited to the area dredged.

Are there any immediate changes in species composition? Analysis of variance by taxonomic group indicates that, at the second study site, the mean number of insects in each group was the same at all five sections before dredging began (Table 2). After dredging, all groups showed significant $\mathrm{P}(\mathrm{F}<.05)$ variation between sections. Scheffe's test showed section two, the dredged area, contained significantly fewer organisms than the other sections (Table 2 ). Although some of the species show increases or decreases in the downstream sites relative to the control, none of these changes are great enough, or consistent enough, to warrent a conclusion that there are any immediate downstream impacts on any of the species. The data at the first study site are less clear. At the ordinal level of taxonomic resolution, it is again fairly clear that the abundance of insects in section two is greatly decreased and in the other sections there are no quantitative changes. However, at finer levels of taxonomic resolution the ability to detect changes in species density becomes weaker. Some of the genera do not show statistically significant differences between sections after dredging. However, in every case except one, section two contains fewer 
TABLE 2

Results of oneway analysis of variance

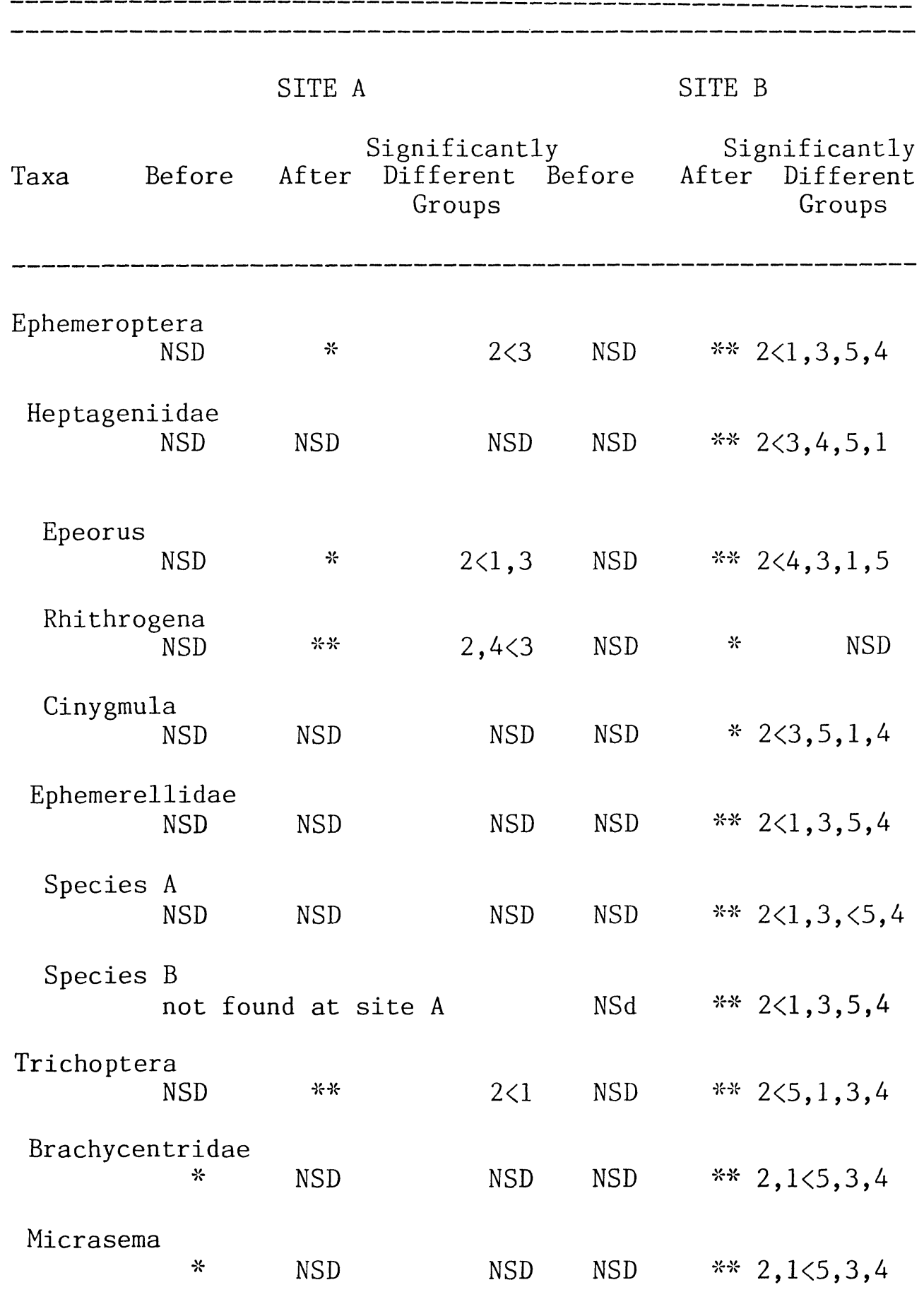


TABLE 2 (continued)

SITE A

SITE B

Taxa Before After Different Before After $\begin{gathered}\text { Significantly } \\ \text { Different } \\ \text { Groups }\end{gathered}$

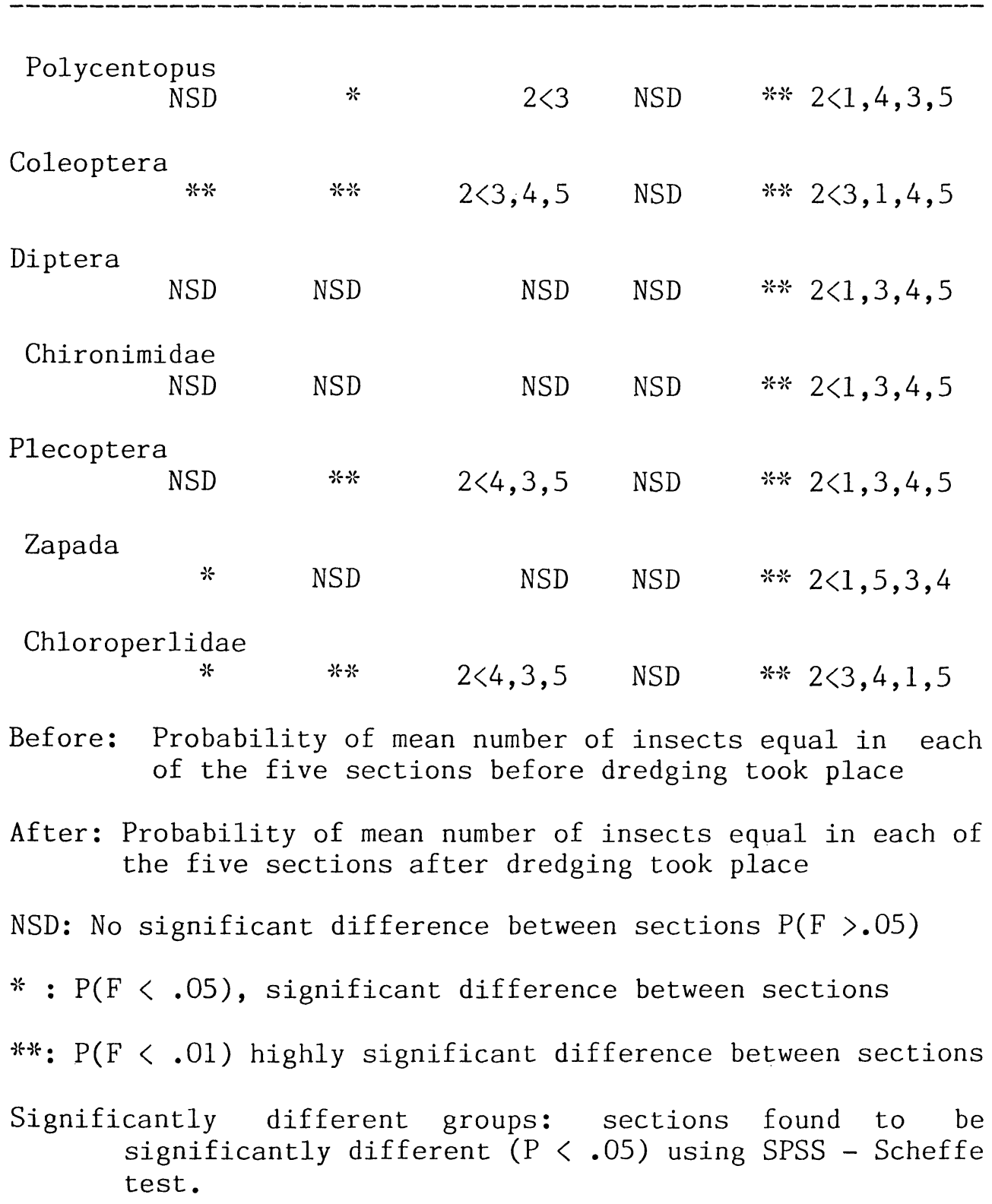


organisms than any other section after dredging, regardless of the abundance of insects in section two before dredging. The trend for a large decrease in insects in section two after dredging is consistent.

The data suggest that the immediate effect of suction dredging is to reduce the numbers of all species of aquatic insects in the area dredged. The effect is very localized. No significant change in abundance was found downstream from the dredged section for any taxonomic group

Recolonization was substantially complete for most groups of insects one month after dredging. Analysis of variance indicates that the mean number of aquatic insects was not significantly different between sections 1,2 , and 3 one month after dredging (Table 3). Only the Trichoptera (caddis flies) had significantly lower numbers in the dredged section than in sections one or three one month later (Figure 9). At site $B$ the mean number of caddisflies downstream of dredging decreased relative to the control section. Both sections 2 and 3 have significantly fewer caddisflies than the control (Figure 9). At site A the caddisflies did not fully recover in the dredged section, but no downstream impacts were indicated.

The Coleoptera (family Elmidae) at site A showed significantly higher numbers in the first downstream section than in section one or two. This result was not substantiated at site $B$ where Elmids did not increase downstream of dredging 
TABLE 3

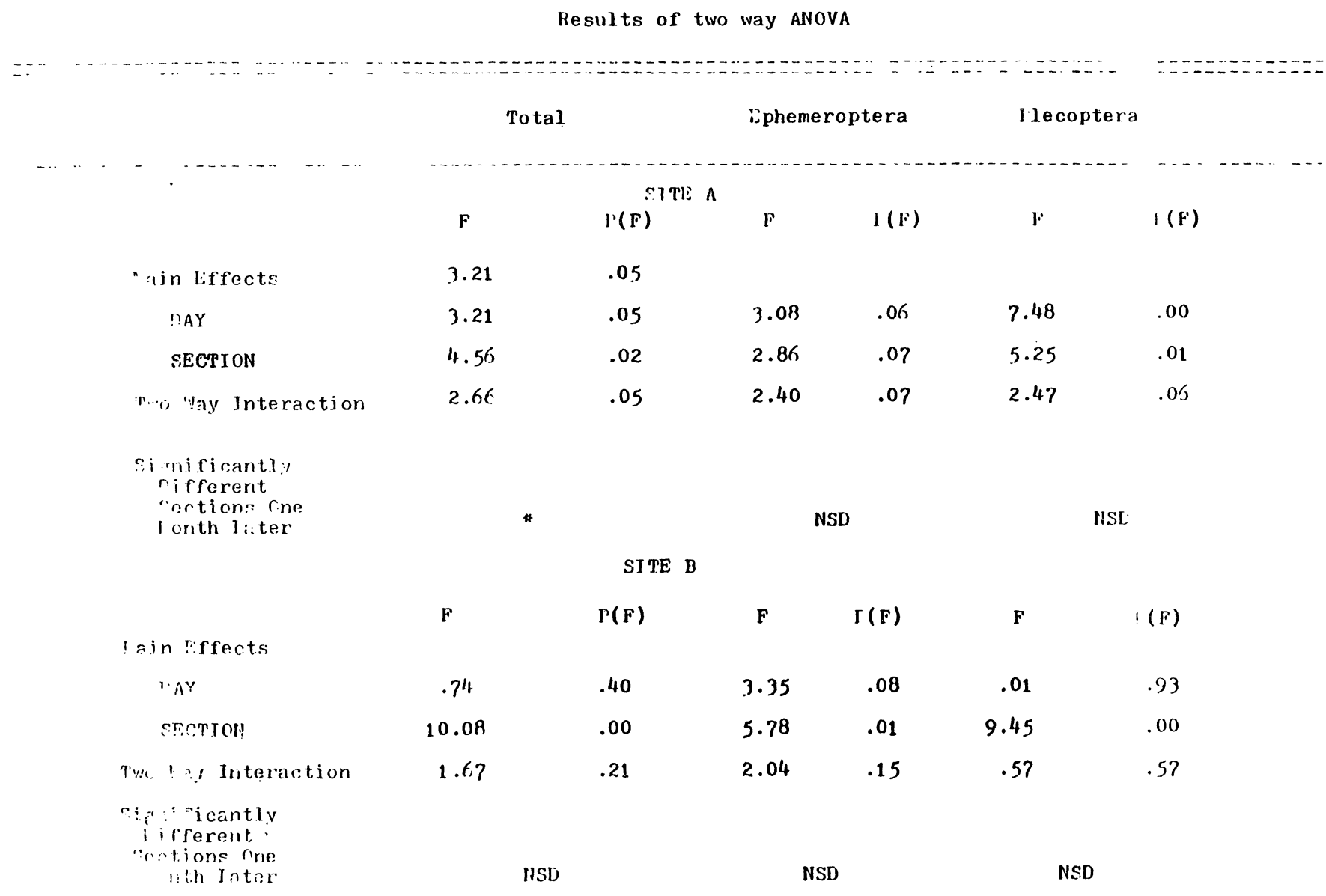


T'ABIE 3 (cont.)

Results of Two Vay ANOVA

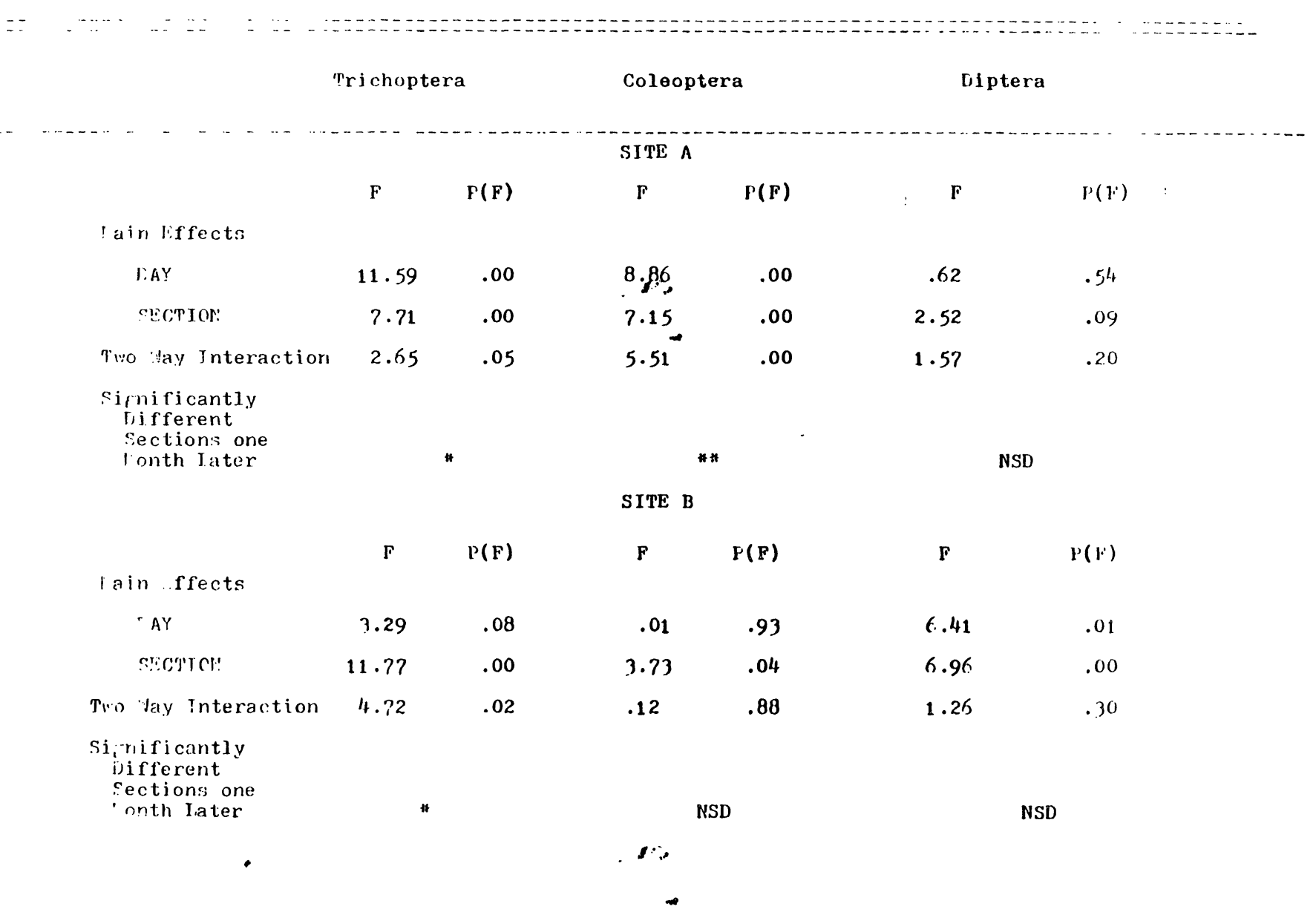




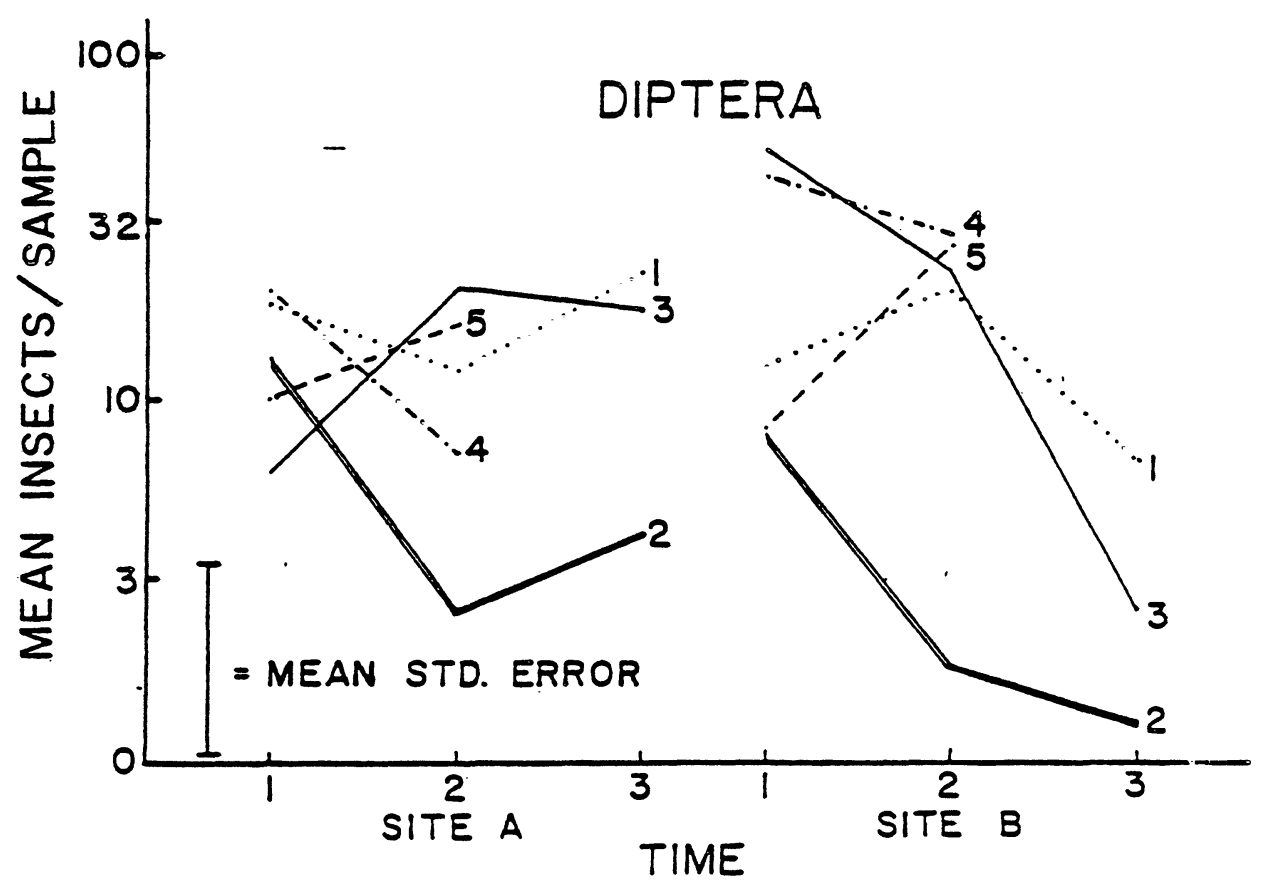

FIGURE 9. Changes in insect abundance over time, by order. Time 1 = before dredging, Time $2=1$ day after dredging, Time $3=1$ month after dredging. 


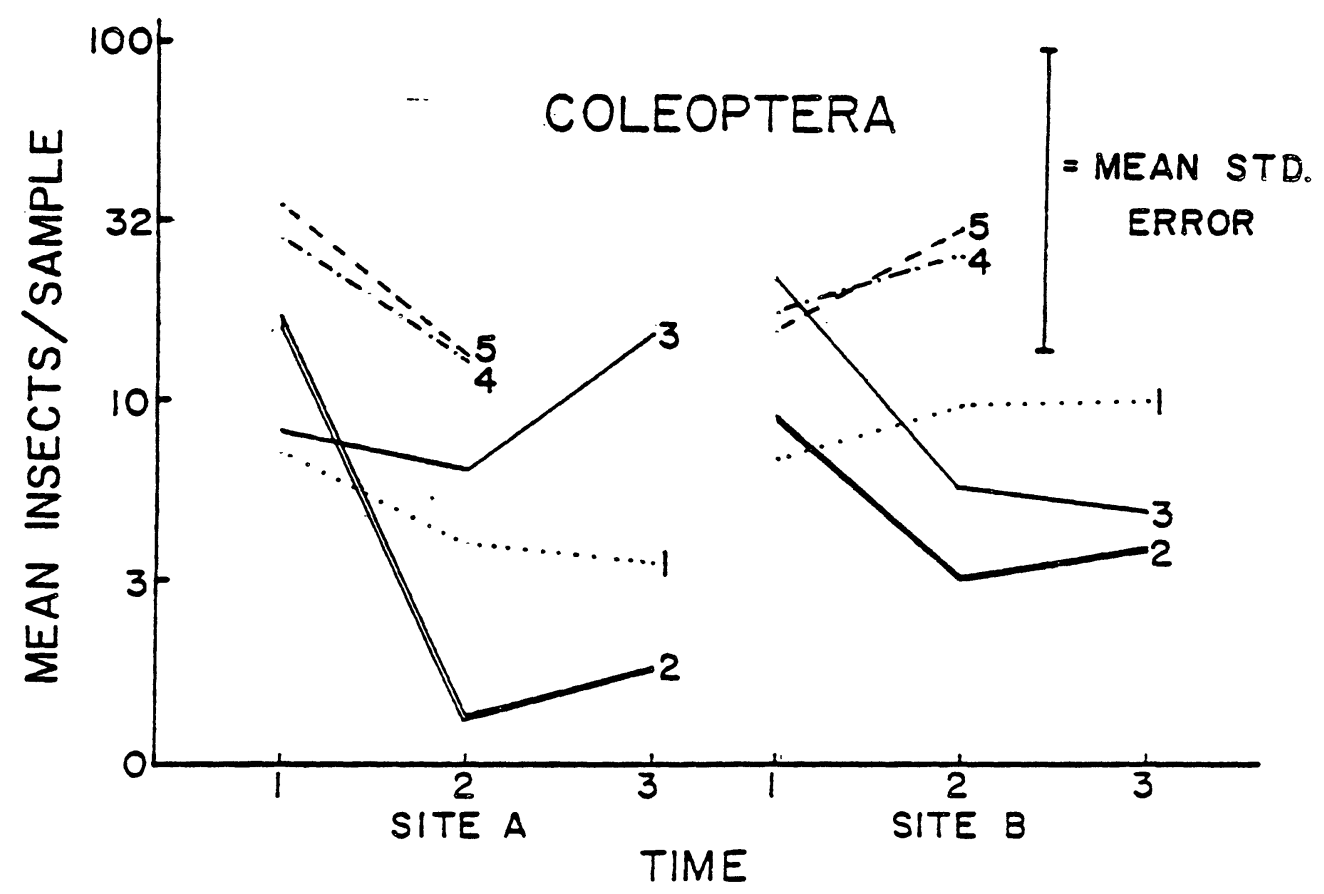




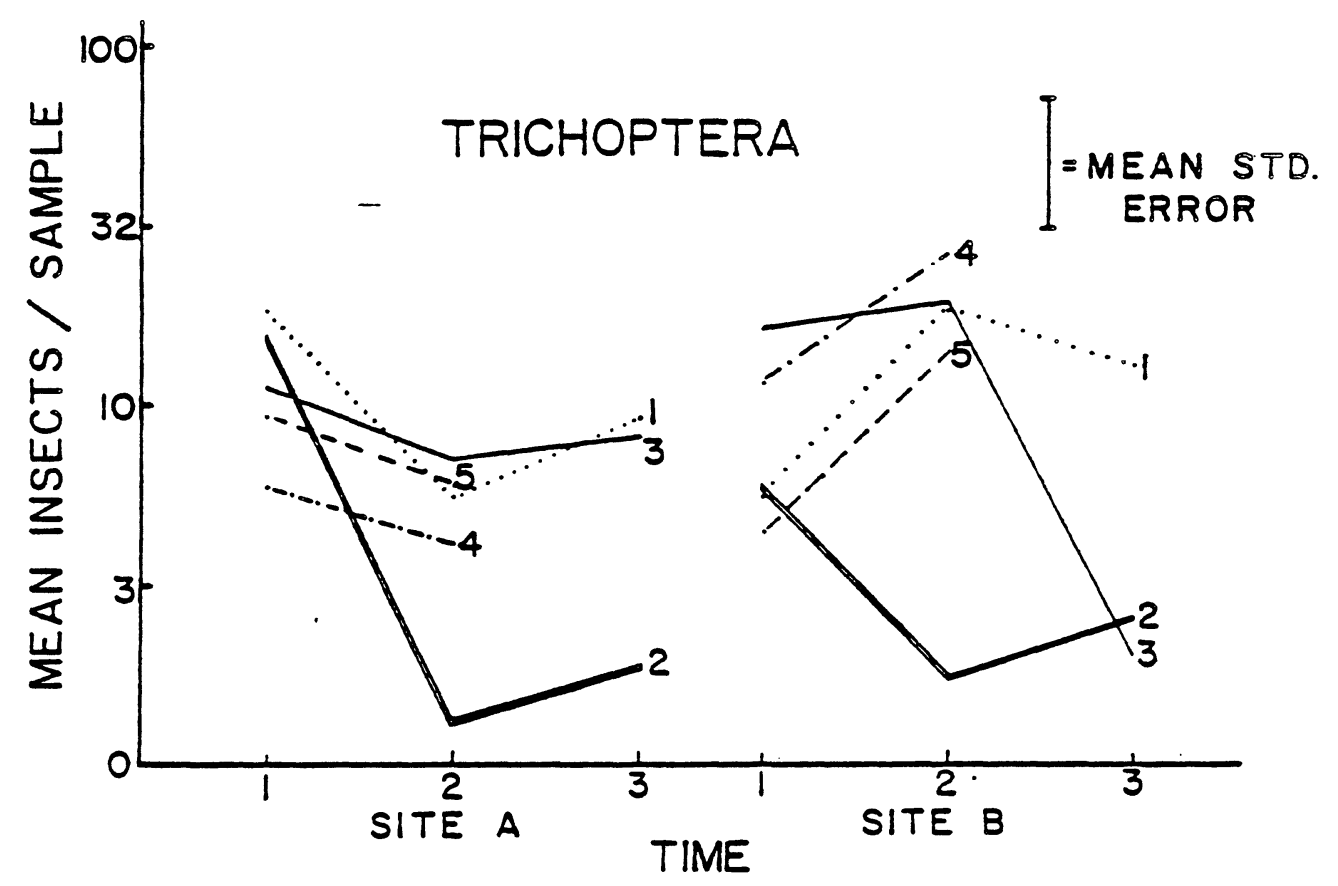




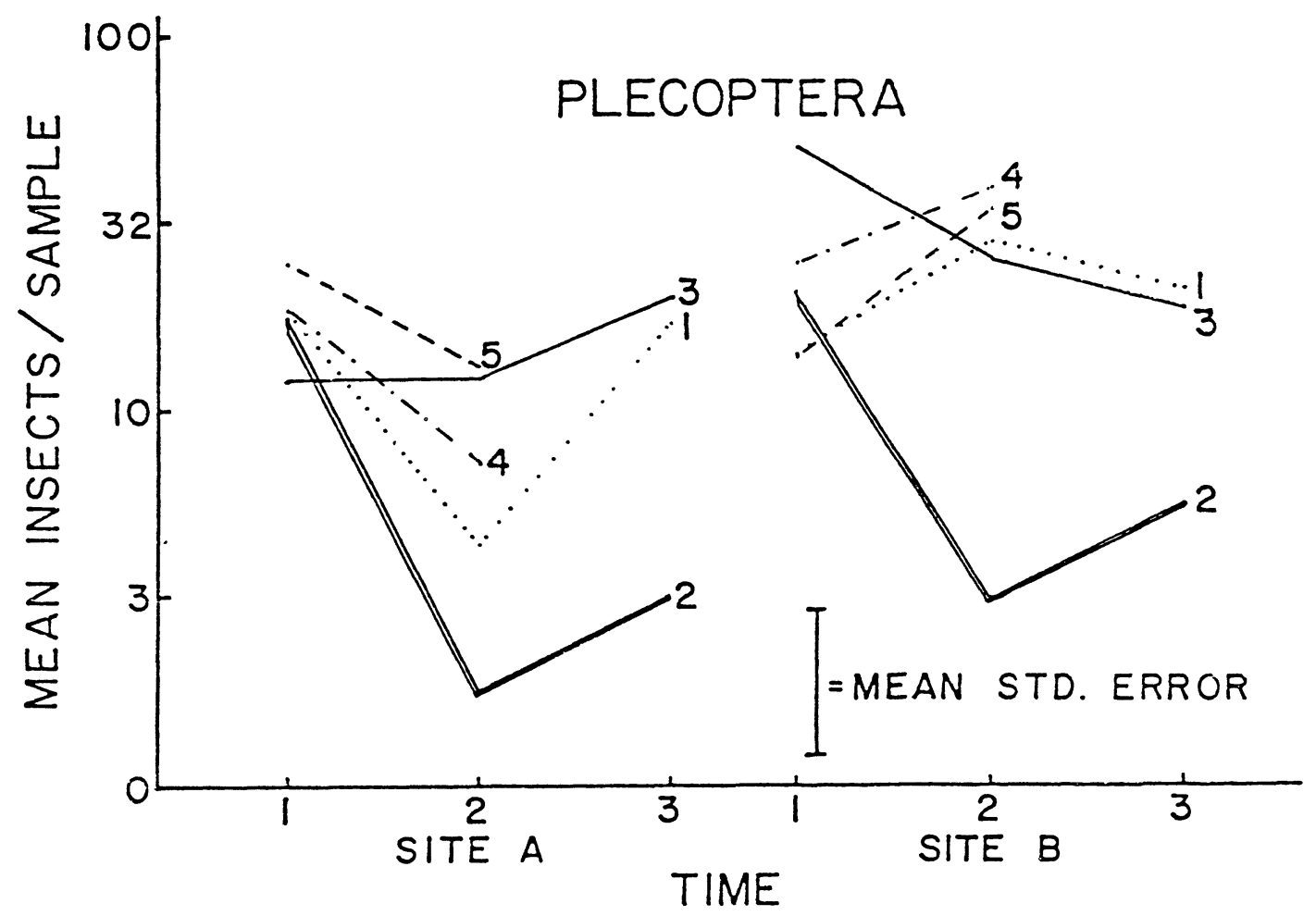




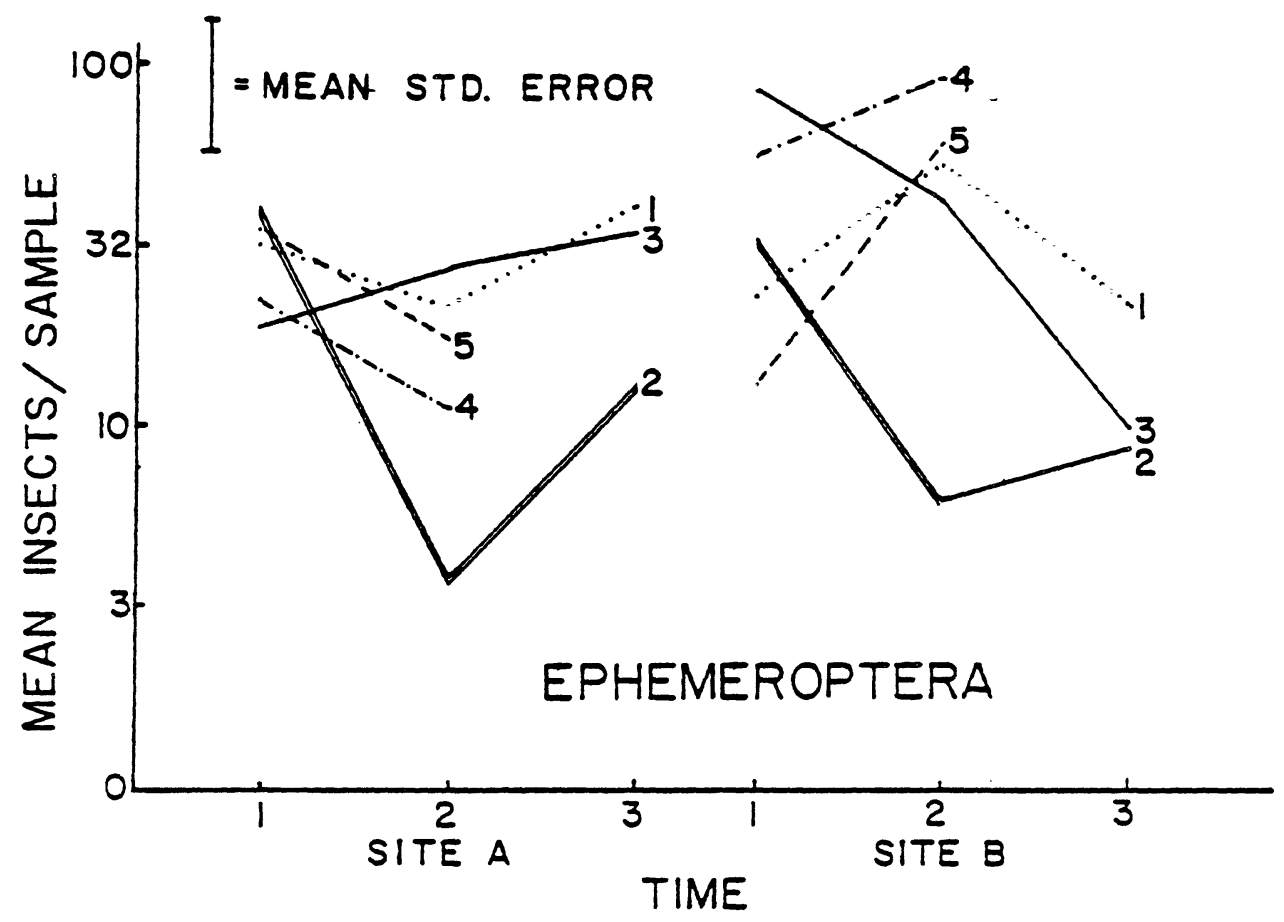


and there was no significant difference between sections.

A two way ANOVA comparing the numbers of insects after dredging to the numbers of insects after a recolonization period shows significant time $X$ section interaction only for the caddisflies at site 2 (Table 3 ). None of the other interaction terms were significant, indicating no significant downstream effects of dredging. It appears that downstream sediment deposition due to dredging may have negatively impacted the caddis flies at site 2. However, since the caddis flies were not impacted at site 1 , the evidence is inconclusive.

In every case but one, the number of insects in the dredged section increased after dredging, even when the numbers in the control and downstream sections were decreasing. This indicates the aquatic insects do find dredged areas to be suitable habitat. However, in almost every case the numbers in the dredged section after one month remained below that of the control and downstream sections. It is possible that it takes longer than 30 days for complete colonization to occur or that dredging reduces the carrying capacity of the substrate.

SUSPENDED SEDIMENT

Upstream of the dredge outflow the mean quantity of suspended sediment was $4.56 \mathrm{mg} / 1$. The concentration of suspended sediment was greatest at the dredge outflow and decreased rapidly downstream as the heavier particles settled out and the remaining material dispersed across the 
width of the stream (Figure 10 ). One hundred feet $(30.5 \mathrm{~m}$ ) below the dredge, suspended sediment was $1.8 \mathrm{mg} / 1$, indicating a return to ambient levels. The rate of decrease in suspended sediment will vary with stream discharge and particle size.

Sediment discharge measured upstream of the dredge was 651 1bs/day (290 kg/day) on August 21st. The same day sediment discharge was $78,068.3$ 1bs/day $(35076.5 \mathrm{~kg} /$ day $)$ at the dredge outflow and $755.8 \mathrm{lbs} /$ day $(343.5 \mathrm{~kg} /$ day $)$ thirty -five feet $(10.7 \mathrm{~m}$.$) below the outflow. However, this is a point$ estimate of the worst sediment discharge experienced in Gold Ck., and not a true representation of the average amount of sediment being discharged during dredging. In order to accurately estimate sediment discharge many samples would have to be taken at the dredge outflow over the course of a day . 


\section{SUSPENDED SEDIMENT}

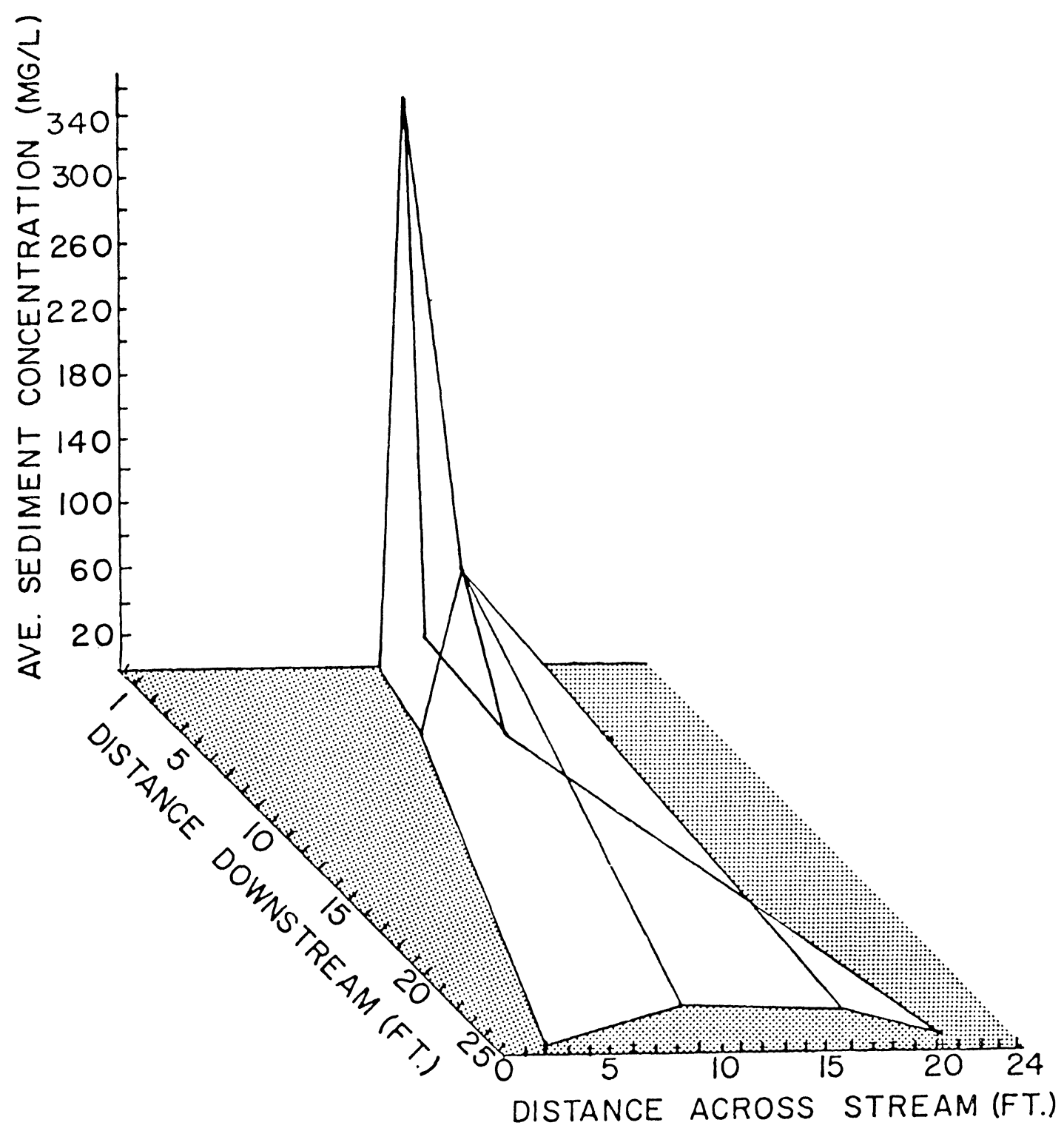

FIGURE 10. Suspended sediment concentration downstream from dredging. 
DEPOSITED SEDIMENT

Deposited sediment measured before dredging was equal throughout the stream, with a mean of $1.96 \mathrm{~g} . /$ trap . After dredging, deposited sediment increased 10 to 20 times over background levels immediately downstream (Figure 11 and 12). Deposited sediment decreased as a power function downstream with the the distance from dredging. Deposited sediment at site $A$ is described by the following equation:

$$
Y=42.43 e^{-.067 x} r^{2}=.42
$$

and at site $B$ by the equation:

$$
Y=34.54 e^{-.032 x} r^{2}=.45
$$

where $\mathrm{Y}=$ deposited sediment and $\mathrm{x}=$ distance downstream from dredging. Apparently more sediment was disturbed at site $A$, but the quantity drops off at a faster rate downstream. Thirty meters downstream site A is actually nearer ambient levels of deposited sediment than site $B$.

There is a high variance of the downstream deposited sediment measurements primarily because the sediment was not distributed equally across the stream. More of the sediment was distributed near the middle of the stream than near the edges, which received near backround levels of sediment.

The quantities of sediment measured in this experiment are only useful for comparison purposes. Unfortunetly it was 


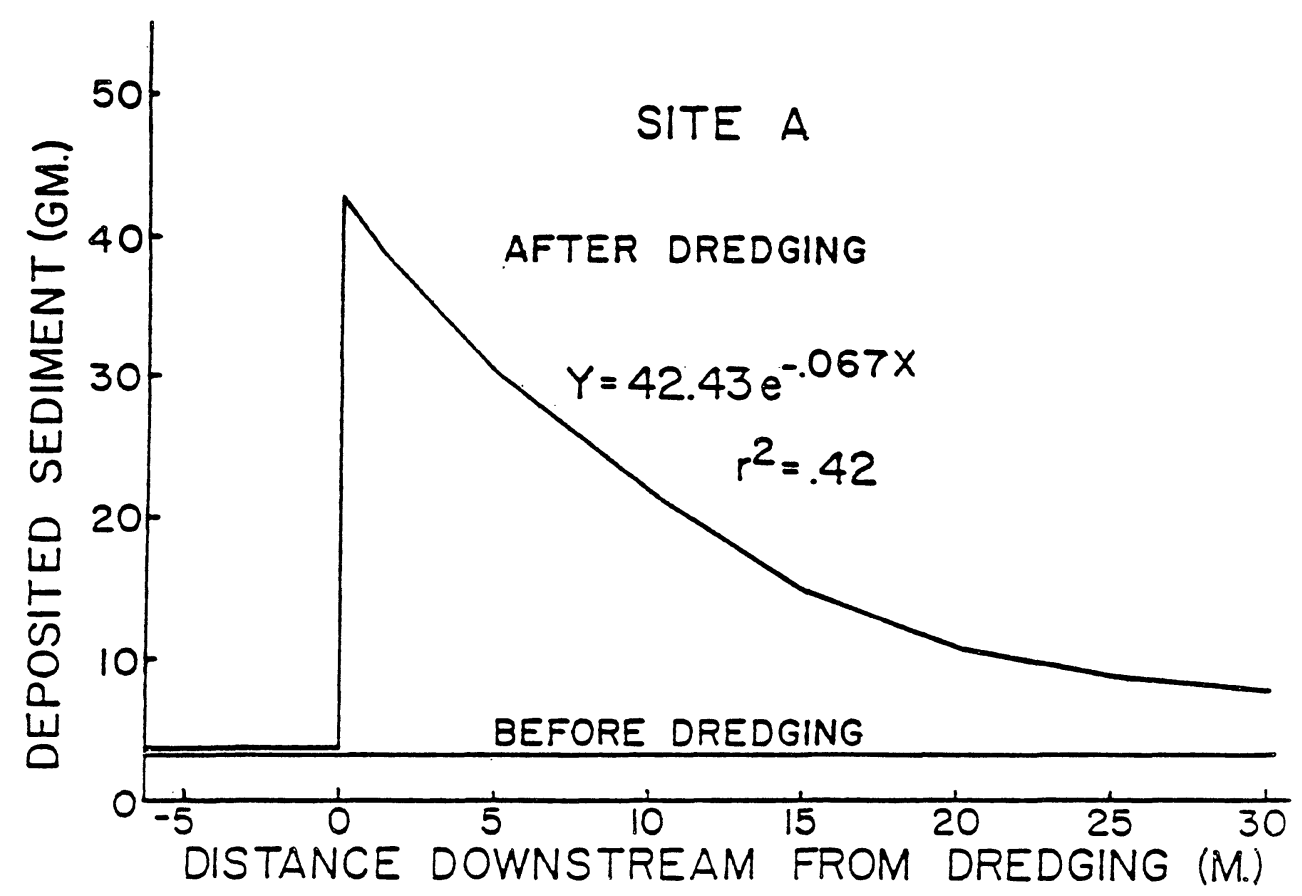

FIGURE 11. Deposited sediment before and after dredging at Sice A. 


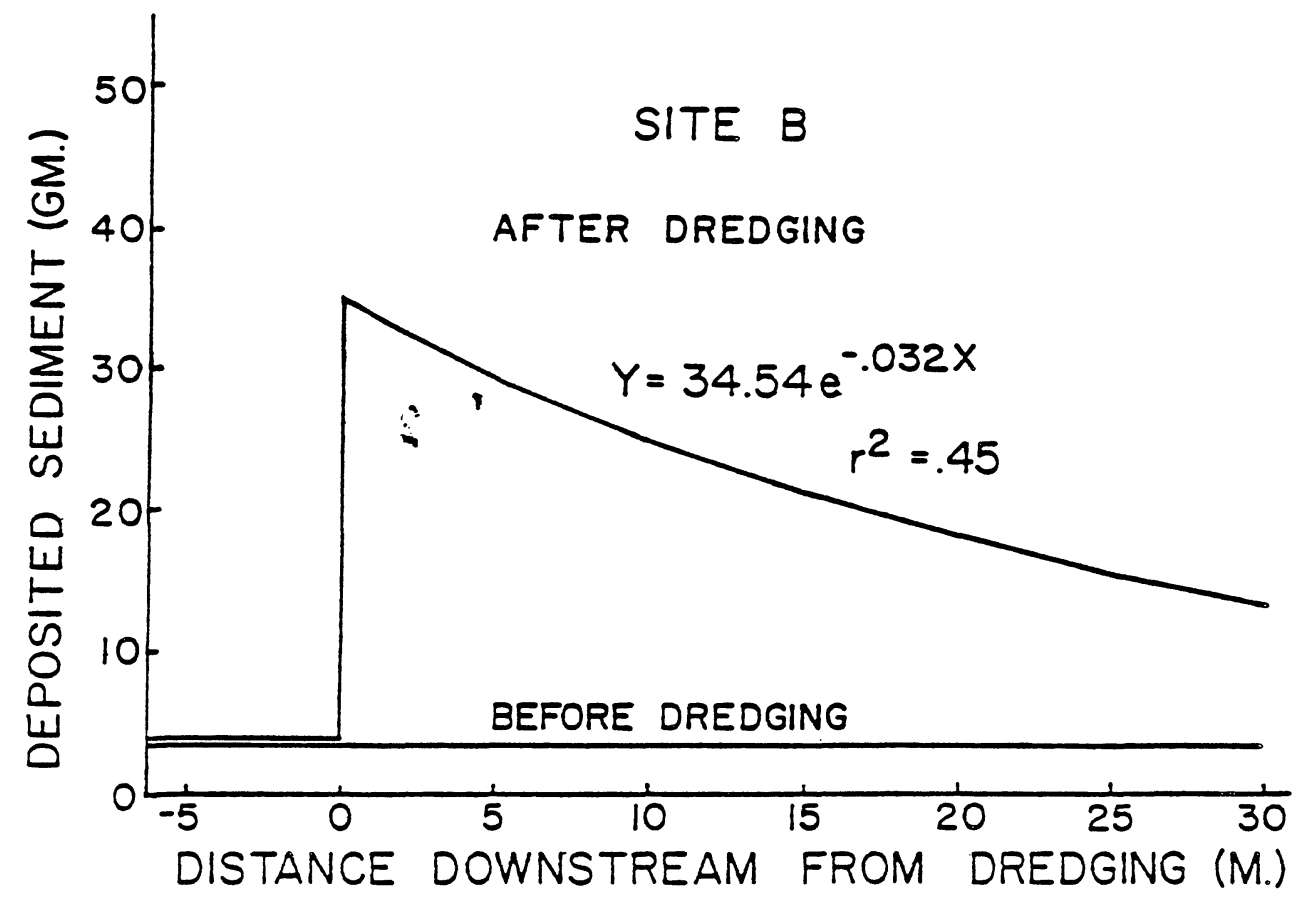

FIGURE 12. Deposited sediment before and after dredging at Site 
not possible to leave the traps in place for just 24 hours at a time to get a daily rate of sediment deposition. Instead the values measured represent four days sediment deposition.

\section{TURBIDITY}

Turbidity samples taken upstream of dredging showed a background turbidity of $1.2-1.5$ NTU. Turbidity measured $25 \mathrm{ft}$ downstream of the operating dredge showed a mean of 2.4 - 3.9 NTU. Under Montana law it is illegal to cause an increase in turbidity of more than 5 NTU $500 \mathrm{ft}$ downstream from an effluent source. A sample taken at the dredge outflow measured 32 NTU. However, turbidity was highly variable depending on where the samples are taken and the type of substrate being dredged at the time of sampling. If the dredge is working in the middle of the stream a sample taken near the stream banks will not show increased turbidity. Dredging sandy, muddy bottoms increases turbidity a great deal more than dredging gravel. Although the mean turbidity downstream of the dredge was only slightly elevated, the samples ranged from 1.2 NTU (no increase above ambient levels) to 7.7 NTU (a noticable increase above ambient levels). It is apparent that turbidity decreases rapidly downstream of a suction dredge and probably returns to ambient levels across the stream within $100 \mathrm{ft} .(30.3 \mathrm{~m}$.$) . This is despite the effort made to$ take samples when the dredge outflow was at its dirtiest. 
CHANNEL MORPHOLOGY

The results of the channel morphology mapping were very unsatisfactory. A much higher density of transects needed to be mapped. In addition, there was too much error in the transects taken to show the changes that took place.

The dredging technique used by the operator will have a large effect on the types of changes that will occur in channel morphology. A miner who dredges one deep hole will have more impact on channel morphology than a miner who dredges a greater area to a shallow depth. Since most of the gold will be found at or near bedrock, most miners will find it necessary to dig a deep hole with their dredge.

Gravel is deposited in piles immediately downstream of the dredge outflow (Figure 13). These piles could make excellent spawning sites except that they are very unstable. One year after dredging, all the gravel deposited at the dredged area had been moved downstream. In one case, the gravel was moved into a downstream pool, completely filling it up. Bjornn, et.al.(1977) found that when fines were added to pools in a test stream, the abundance of fish decreased proportionally to he decrease in pool volume or area. It is unknown whether or not the pool habitat created upstream by dredging deep holes would compensate for the loss of pool habitat downstream.

Any rock too large to fit through the dredge intake has to be removed from the miner's path. At study site A I moved 


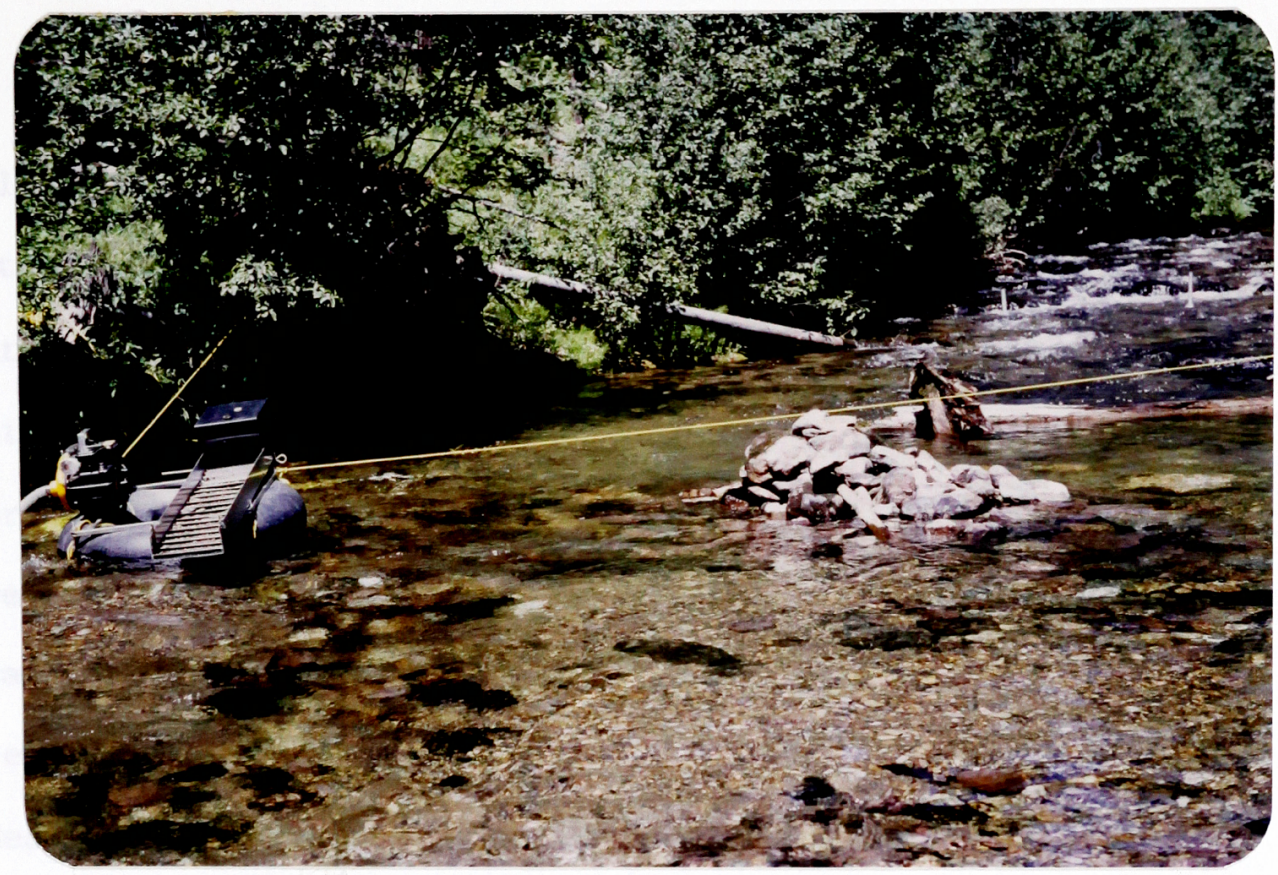

A.

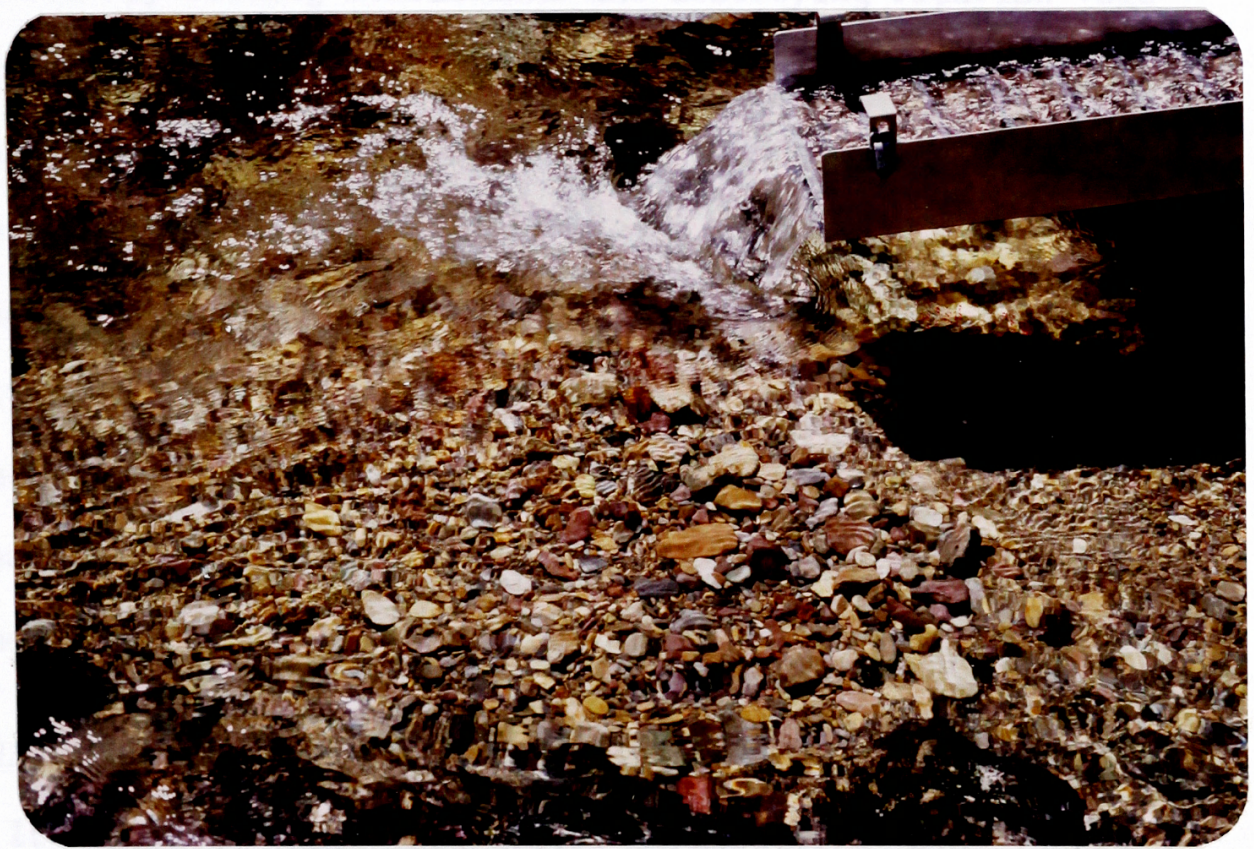

B.

FIGURE 13. A. Gold Ck. during dredge operation. Tailings piles visible just below the dredge and just downstream of the large boulder pile. B. Close up of dredge tailings. 
all the boulders into several piles in the middle of the stream. At site B, I moved the boulders to the edge of the stream (Figure 14). From the pictures it is obvious that piling the boulders in the middle of the stream makes a greater impact. Indeed, when I returned to the study site a year after dredging it was difficult to see that dredging had been done at site B. However, at site A the boulder pile remained in the stream, although somewhat reduced in size, despite high spring flows (Figure 15).

As already mentioned, dredge miners could damage the stream by cutting streambanks and destroying riparian vegetation. This is illegal in Montana. I chose not to damage the streambanks in Gold Ck. for this study. It is possible for a suction dredge to make highly localized changes in channel morphology. Pool and riffle configuration can be altered. The degree of damage is largely determined by the amount of material discharged into the stream. Very large quantities of material could fill pools and change a single channel stream into a braided stream.

\section{GRAVEL PERMEABILITY}

It appears that intergravel permeability did increase slightly in the dredged section after dredging (Figure 16). However, this difference was not significant (P> .05). There does not appear to be any changes in downstream permeability due to silt deposition from suction dredge mining. In addition, no detectable change occured in intergravel 


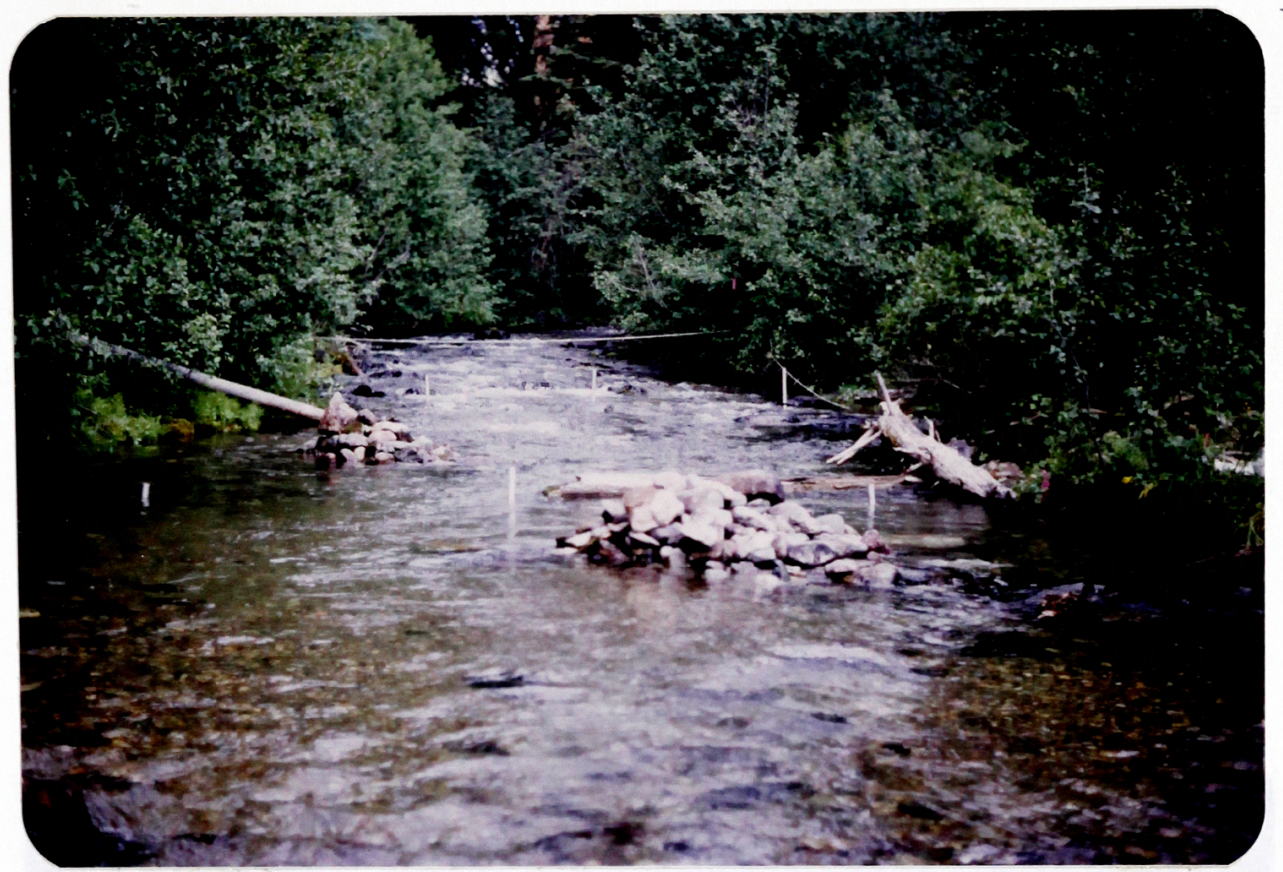

A.

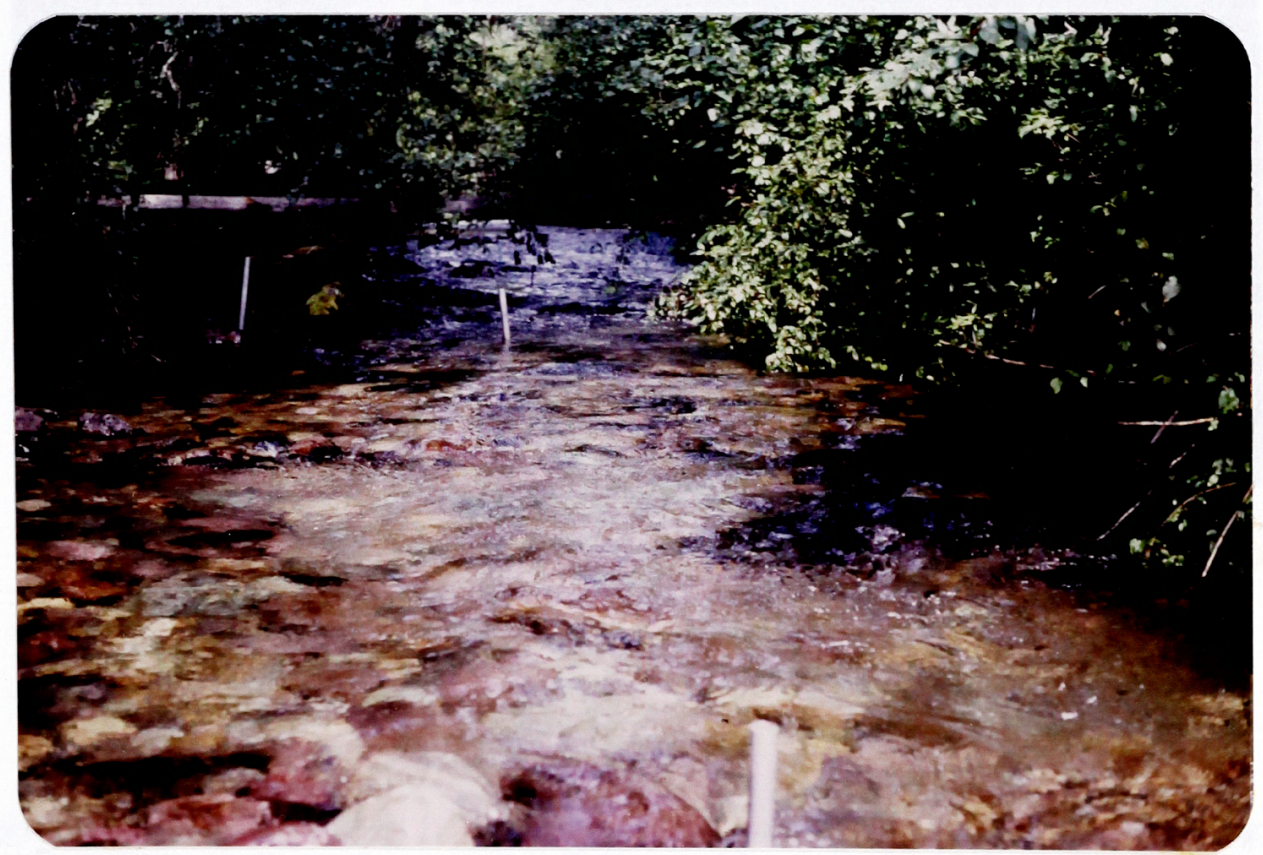

B.

FIGURE 14. A. Site A after dredging. Notice 2 large boulder piles in the stream created by the author during dredging. B. Site B after dredging. Large rocks were piled on the side of the stream (out of view of the picture). 


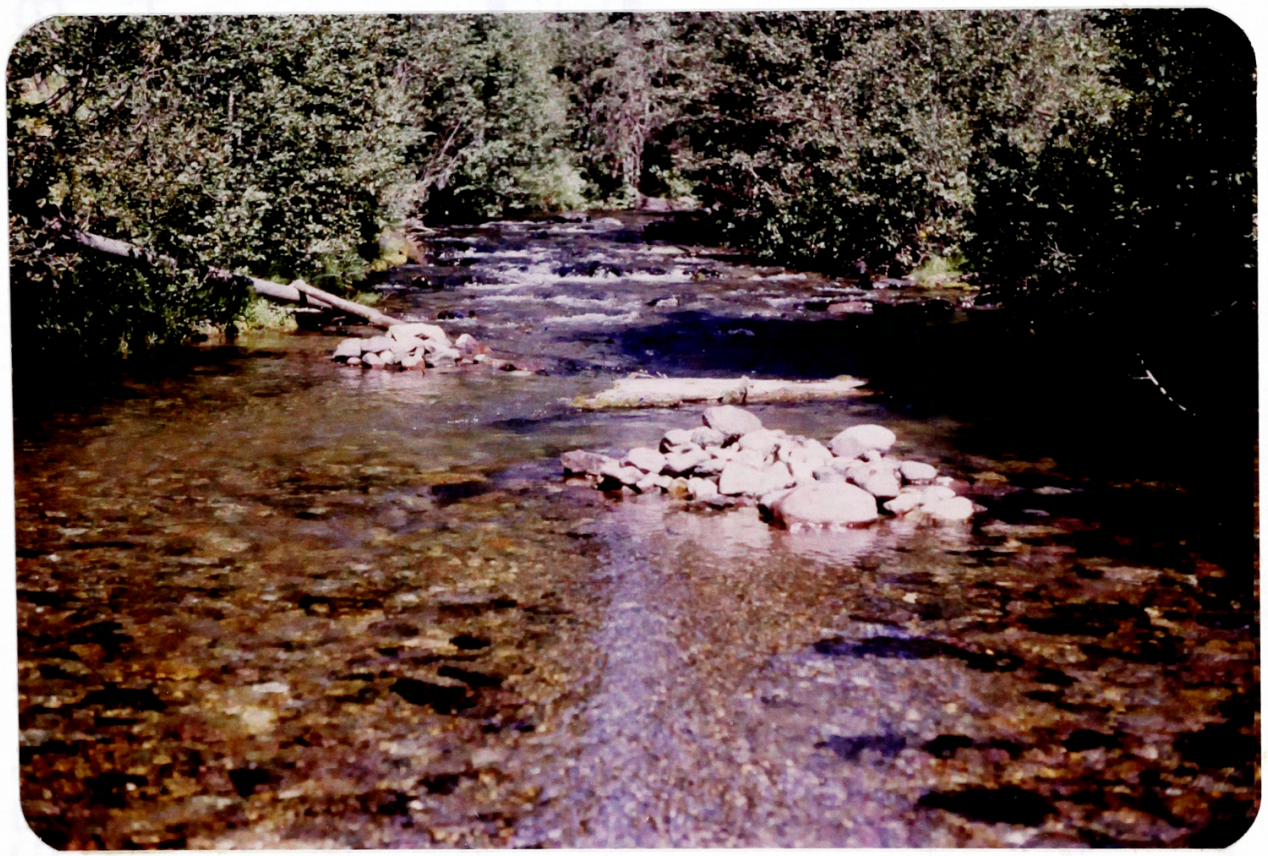

FIGURE 15. Site A one year after dredging. High spring flows reduced the size of the boulder piles but did not remove them. 


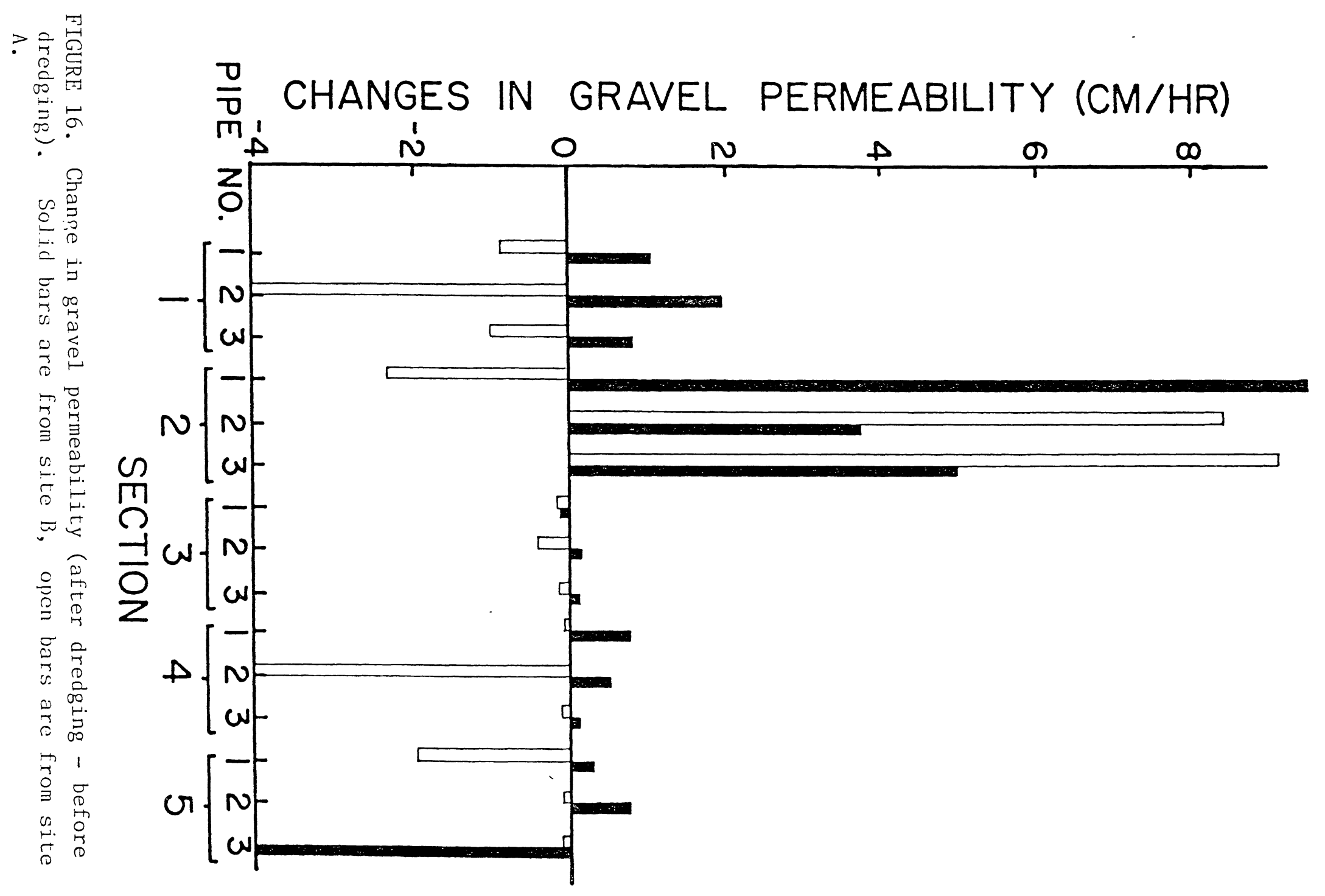


water dissolved oxygen. However, the dissolved oxygen meter used was not reliable and it was difficult to obtain a sufficient number of readings using Winkler titrations. It is possible that changes did occur that were not detectable because not enough samples were taken and tested with reliable Winkler titrations. In contrast, Lewis (1962) found an average site improvement of $1 \mathrm{ppm}$ in dissolved oxygen and a threefold improvement in permeability after dredging. However, the stream where he worked was heavily silted and compacted before dredging.

The data indicate that silt depostion from suction dredge mining should not be detrimental to developing salmonid eggs. However, it is possible that harm could be caused if the dredge were larger, the stream smaller, or the substrate more silty. In a stream where intergravel flow and dissolved oxygen were marginal to begin with, a small decrease in permeability could cause a decrease in salmonid growth rate. 
DISCUSSION

Griffith and Andrews (1981) found that aquatic invertebrates entrained through a suction dredge have a one percent mortality rate within 24 hours of entrainment. Lewis (1962) found $7.4 \%$ benthos mortality after passing through a suction dredge, but thought that figure to be high. In addition, Griffith and Andrews (1981) observed very few insects to have noticable external damage as a result of entrainment and that most of the insects settled to the bottom within 10-20 m. of dredging. However, my study did not find increased densities of insects downstream of dredging. It is possible that the entrained insects are unable to find suitable unoccupied habitat in the immediate downstream area. In addition, insects set adrift in the daytime might be expected to suffer high predation rates. In fact, during dredging, cutthroat trout (Salmo clarki) were observed swimming in the area of the dredge outflow, feeding on dislodged invertebrates. Lewis (1962) observed a similar phenomenon, with up to 12 squawfish (Ptychocheilus sp.) feeding on insects on the outflow tail.

Although the sediment sampling demonstrated that the bulk of the fines are redeposited within $20 \mathrm{~m}$. of dredging, no immediate downstream decrease in aquatic insect density could be detected. One month after dredging there was no significant difference between the control section and the downstream section except for the caddisflies at site B. McClelland and Brusven (1980) tested several species of 
Ephemeroptera, Plecoptera, and Trichoptera to determine their response to introduced sediments. They found the Plecoptera to be the most sensitive, followed by the Trichoptera,with the Ephemeroptera being least sensitive. The lack of response of these orders to sediment introduction in Gold Creek may indicate that the quantity of sediment produced by dredging was not enough to create an impact or that the insect species in Gold Creek (which are not the same ones McClelland and Brusven tested) are more sediment tolerant.

The sides and undersides of cobble size rocks $(10-15 \mathrm{~cm}$ in diameter) are often important habitat for aquatic insects. Unimpacted cobble permits maximum inhabitation around cobbles, particularly to insects that cannot burrow, have exoskeletal armature or body size inhibiting interstitial burrowing, or have the habit of living under or on the surface of cobbles (Brusven and Prather, 1974). The critical factor determining to what degree sediment impacts the stream benthos may be the degree of sealing of undersides of cobbles. As the quantity of sediment increases more of the critical under cobble microhabitat becomes unavailable, thus reducing the percentage of cobbles harboring insects (McClelland and Brusven, 1980).

There are qualitative changes in the stream bottom habitat on the area dredged. As mentioned earlier, the distribution of benthic insects is highly dependent on substrate particle size (Cummins and Lauf, 1969). Dredging removes all the 
bottom material smaller than the intake nozzle diameter. This should result in changes in species compostion in the area dredged. Dredging also changes water depth. Although the mean depth of the area may or may not have been changed, the variablity of depth was increased by the creation of deep pools and shallow bars where the area was previously a uniform riffle. These changes would also probably lead to a different aquatic insect community. In addition, Hart (1978) found the number of aquatic insect species per area was higher on small rocks (average surface area $95 \mathrm{~cm}$ ) than large rocks (average surface area $602 \mathrm{~cm}^{2}$ ). Therefore dredging may decrease the number of species in the area.

However, with a $2.5^{\prime \prime}(6.4 \mathrm{~cm})$ dredge, cobble size rocks remain in the stream, completely cleaned of any sediment seal. This would have a beneficial effect on the stream benthos. A dredge with a 6 inch nozzle would be capable of removing cobbles from the area dredged. The resulting substrate would either be bedrock or large rocks. This type of bottom would not be quite so favorable.

At study site $B$ where large boulders were piled in the stream, islands were created that would not support any aquatic life. However, dredging does remove the fines from the area which might partially compensate for the negative impacts listed above.

The purpose of this study was to assess the impact of one small dredge operated for a relatively short period of time. The effects seem to be small, very localized habitat modifi- 
cations which had a minimal effect on the stream community. However, small modifications occuring over time and/or in a number of places within a watershed can often reach levels resulting in major biological and ecological change. For example, the effects of sediment should always be considered in the context of the whole drainage network. Fine sediment exported from high drainage headwater channels deposits downstream where the gradient is lower. Imputs from a large number of disturbed tributaries might overload downstream reaches with sediment and reduce water quality and aquatic productivity (Murphy, et.al.,1981). We are beginning to find out how much sediment deposition streams can handle before serious damage begins to occur (see Bjornn, et.a1., 1977 and Brusven and Prather, 1974). We do not know how much suction dredging will produce that quantity of sediment. We do not know at what point dredging begins to have other, nonsediment related impacts. Further research should be directed at defining the threshold of environmental degradation. 
LAWS AND REGULATIONS GOVERNING SUCTION DREDGE MINING IN THE STATE OF MONTANA

Under current Federal and Montana state law, a person proposing to dredge for gold needs six different permits, depending on the location of their site. A stream discharge permit is required for gold dredge operations under the Montana Water Quality Act administered by the Montana Department of Health and Environmental Sciences, Water Quality Bureau. A general permit is issued to dredges less than 4 inches in size. The Department of Fish, Wildlife, and Parks makes recommendaions on a season for dredging for these permits. Larger dredge operations are considered individual1y. The requirements for this permit are the most rigorous. The permit must be applied for 180 days in advance of the proposed operation. The effluent limitation allows for an increase in instream turbidity of 5 NTU. Under the self monitoring requirements instream turbidity must be measured ten feet upstream of the operation and not more than 500 feet below the point of discharge. Turbidity must be measured by grab sample at least once upon start up each year and at least once every fifteen days of actual operation. Samples must be analyzed in the best manner technologically feasible. Results must be reported to the Environmental Protection Agency and the Montana Department of Health and Environmental Sciences every month. There are a number of other regulations that apply to this permit (Appendix A). 
Before a person can divert or impound water for a new use or change an established use, they must receive a permit from the Montana Department of Natural Resources and Conservation, Water Rights Bureau. This includes water used for the purposes of suction dredge mining. The granting of the appropriation is contingent upon there being no objections from downstream water users.

The Montana Department of State Lands administers the Metal Mine Reclamation Act which requires licensing of persons engaged in exploration and permits for development of mining properties. An application, bond, and fee are required. Small miner exemptions are granted for persons mining less than 36,500 tons per year and disturbing less than five acres.

Under the state of Montana Natural Streambed and Land Preservaton Act, a miner proposing to work within the high water marks of a perennially flowing stream, must obtain permission from the local Conservation District or the Board of County Commissioners. A "Notice of Proposed Project", with detailed plans, must be submitted. All these permits are first reviewed by the Department of Fish, Wildlife, and Parks. The Department of Fish, Wildlife, and Parks has developed a set of guidelines for reviewing suction dredge permit applications. They are included in Appendix B.

In addition, under the General Mining Law (Mining Law of 1872), a miner working on federally owned lands must obtain 
a mining claim. Previously unclaimed federal land that has not been withdrawn from mineral entry can be claimed. Mining claims may be recorded by filing an exact copy of the location notice in the County Recorder's Office where the claim is located. Claims on public lands must be recorded with the Bureau of Land Management state office having jurisdiction over the area in which the claim is located. Mining claims are only valid after a valuable mineral deposit has been located.

The Federal Water Pollution Act requires a Department of the Army permit, issued by the Corps of Engineers for the discharge of dredged or fill materials into the waters of the United States or on adjacent wetlands. Some minor activities are allowed by nationwide or general permits.

The Montana Department of Health and Environmental Sciences issues suction dredge licenses. The miners must demonstrate that they are aware of applicable state and federal laws and that they are aware of the rights of existing mining claimants and private landowners.

There are a number of other federal, state, and local laws that may apply to a suction dredge miner depending on the exact location, size of dredge, and type of project to be undertaken

Although I do not have any data, I strongly suspect that a number of people are operating suction dredges in Montana without the required permits. Many dredge operators may be unaware of the regulations. Others may know the law but 
feel it is too much trouble to comply. They probably realize the chances of the being caught operating a dredge without a permit is slim. For example, most of the miners who do acquire a stream discharge permit do not file the required selfmonitoring statements. They simply claim they did not operate within the last year. Since it is impossible for the state to check on every dredge miner, there is no choice but to hope that is true. Cooperation of miners is essential to effective protection of the state's waters. There are two ways cooperation could be improved. A public education campaign is needed to inform people of the damage a suction dredge can do and to make them aware of the regulations. In addition, the permitting process could be streamlined.

The state of Washington has published a booklet "Gold and Fish" (Appendix C) which describes the impacts suction dredging can have on streams. It also reviews the permits suction gold dredge operators need and describes the lands and streams where dredging is not allowed. In addition, Washington has classified most of the major streams according to the type of mining activity allowed, the time of year mining is allowed, and the maximum dredge size allowed. The list of classified streams is included in "Gold and Fish". Apparently, the Gold Miners Association of America donated the money for the printing of the pamphlet. In 1981 the state of Montana published a short pamphlet reviewing the laws that apply to dredge operation. The 
addition of a section describing the impacts suction dredge mining has on the stream environment would be very useful. Many miners may feel that the regulations are needless harassment. If they understood the reasons for the regulations they might be more cooperative. It would also be useful to suggest mining techniques that would minimize dredge impacts.

The permitting process could be streamlined by classifying the major Montana waterways in the same way Washington has. A clear stream by stream policy on dredging would reduce decision making time for the state agencies. Additionally, miners will know at a glance if the area they want to work is open for dredging. The self monitoring requirements of the stream discharge permit are well intentioned but not very effective. It is not known how many miners even try to comply. For those who do take the required samples, the regulations do not state the exact location where the downstream samples must be taken. It would be very easy to take the required samples to the side of the main sediment plume and not show any increase in turbidity. Finally,turbidity meters are not generally available to the general public. The best solution is to have state employees monitor dredge operations. Of course this is a very expensive, and probably not feasible, proposal. Probably the most important goal of the state is to get full compliance with the law. Public education is necessary to acheive that goal. 


\section{LITERATURE CITED}

Ambuh1,H. 1959. Die Bedeutung der Stromung als okologischer Faktor. Schweiz. Z. Hydrol. 21:133-264. cited in Luedtke, R.J., and M.A. Brusven. 1976. Effects of sand on colonization of stream insects. J.Fish. Res. Bd.Can. 33:18811886.

Bjornn,T.C.,M.A.Brusven, M.P.Molnau, J.H.Milligan, R.A.Klamt, E.Chacho, C.Schaye. 1977. Transport of granitic sediment in streams and its effects on insects and fish. For.Wildlife. Range Exper. Sta. Bul1. 17. Univer. Moscow, Moscow. 43 p.

Bournaud,M. 1963. Le courant, facteur ecologigue et ethologique de la vie aquatique. Hydrobiol. 21:125-165.

Boussu, F. 1954. Relationship between trout population and cover on a small stream. J.Wildl. Mgmt. 18:229-239.

Brusven,M.A., K.V. Prather.1974. Influence of stream sediments on distribution of macrobenthos. J. Ent. Soc. Brit. Co1. 71:25- 32 .

Campbe11,H.T.1953. Report on biological reconnaissance of the effect of gold dredging and mining operations on Powder River Oregon, Sept 29- Oct 1, 1953. Oregon State Game Commission, 8 p.(processed).cited in Cordone, A.J. and D.W.Kelly.1961.The influences of inorganic sediment on the aquatic life of streams. Calif. Fish and Game. $47: 189-228$.

Campbell, H.T. 1954. The effect of siltation from gold dredging on the survival of rainbow trout and eyed eggs in Powder R. Oregon. Oregon State Game Commission, 3 p.(processed).cited in Cordone, A.J.and D.W.Kelly.1961. The influences of inorganic sediment on the aquatic life of streams. Calif. Fish and Game. 47:189-228.

Casey,0.E. 1959. The effect of placer mning (dredging) on a trout stream. Ann. Prog.Rept. Project F34-R-1, Watr Quality Investigations, Federal Aid in Fish Restoration, Idaho Dept. of Fish and Game. p.20-27 (mimeo). cited in Cordone, A.J. and D.W.Kelly.1961.The influences of inorganic sediment on the aquatic life of streams. Calif. Fish and Game. 47:189-228.

Chutter,F.M. 1969. The effects of silt and sand on the invertebrate fauna of streams and rivers. Hydrobiol.34:5776. 
Cordone, A.J. and S.Pennoyer. 1960. Notes on silt pollution in the Truckee River drainage. Calif.Dept. Fish and Game Inland Fisheries Admin. Rept. no 60-14, 25 p. (mimeo) cited in Cordone, A.J. and D.W.Kelly.1961.The influences of inorganic sediment on the aquatic life of streams. Calif. Fish and Game. 47:189-228.

Cummins,K.W., and C.H. Lauff. 1969. The influence of substrate particle size in the microdistribution of stream macrobenthos. Hydrobiol.34:145-181.

Dixon, W.J. ed. 1981. BMDP:Biomedical Computer Programs, Pseries. University of Coalifornia Press, Berkeley. 880 p.

Duchrow,R.M.and W.H. Everhart. 1971. Turbidity measurement. Trans. Am. Fish. Soc. 100:682-690.

Green,R.H. 1979. Sampling Design and Statistical Methods for Environmental Biologists. John Wiley and Sons, New York. 257 p.

Griffith,J.S., and D.A. Andrews. 1981.Effects of a small suction dredge on fishes and aquatic invertebrates in Idaho streams. N. Am. J. Fish. Manage. 1:21-28.

Gunderson, D.R. 1968. Floodplain use related to stream morphology and fish populations. J.Wild1. Mgmt. 32:507514 .

Guy, H.P. 1970. Laboratory theory and methods for sediment analysis. Techniques of Water Resources Investigations of the U.S. Geological Survey. Book 5, Chap C-1. U.S. Government Printing Office, Wahington, D.C.

Hart, D.D. 1978. Diversity in stream insects: regulaion by rock size and microspatial complexity. Verh.Internat.Verein. Limnol. 20:1376-1381.

Harvey, B.C.,K.McCleneghan,J.D. Linn,C.L.Langley. 1982. Some physical and biological effects of suction dredge mining. Calif. Dept. of Fish and Game Laboratory Rept. 82-3. 30 p.

Inger, R.F. and P.K.Chin.1962. The freshwater fishes of North Borneo. Fieldiana(Zoology) 45:3-268. Cited in Sheldon, A.L. 1968. Species diversity and longitudinal succession in stream fishes. Ecology. 49:193-198.

Iwamoto, R.N., E.O.Salo,M.A. Madej, R.L. McComas, R.L. Rulifson.1978. Sediment and water quality: a review of the literature including a suggested approach for a water quality criterion. U.S. Env. Prot. Ag. Seattle. 248 p. 
Lewis, R. 1962. Results of gold suction dredge investigation.

State of Calif, memo. Sept. 17, 1962.

Luedtke, R.J., and M.A. Brusven. 1976. Effects of sand on colonization of stream insects. J. Fish. Res. Bd. Can.33:1881- 1886 .

Mason, W.T. and P.P. Yevich. 1967. The use of phloxine B and rose bengal strains to facilitate sorting benthos samples. Trans. Amer. Microsc. Soc. 86: 221-222.

McClelland, W.T. and M.A.Brusven.1980. Effects of sedimentation on the behavior and distribution of riffle insects in a laboratory stream. Aquatic Insects. 2:161-169.

Meehan, R.W. and D.N. Swanson. 1977. Effects of gravel morphology on the fine sediment accumulation and survival of incubating salmon eggs. USDA Forest Service Res. Paper PNW-220.

Murphy, M.L.,C.P.Hawkins, and N.H.Anderson.1981. Effects of canopy modification and accumulated sediment on stream communities. Trans.Am. Fish.Soc. 110:469-478.

Nie, N.H.,C.H.Hul1,J.G. Jenkins,K.Steinbrenner, D.H. Bent. 1975. SPSS: Statistical Package for the Social Sciences. McGraw- Hi11., New York. 675 p.

Nuttall,P.M. and G.H. Bielby.1973. The effect of china-clay wastes on stream invertebrates. Environ. Pollution. 5:77-86.

Pollard,R.A.1955. Measuring seepage through salmon spawning gravel. J.Fish Res. Bd Can.12:706-741.

Rulifson, R.L. 1979. Sedimentation. Fisheries. 4:52-54.

Sheldon, A.L. 1968. Species diversity and longitudinal succession in stream fishes. Ecology. 49:193-198.

Silver, W. and P.Douderoff. 1963. Dissolved oxygen requirements of developing steelhead trout and chinook salmon at different velocities. Trans. Am. Fish Soc. 92:327343.

Snedecor, G.W. and W.G.Cochran. 1980. Statistical Methods. Iowa State University Press, Ames. 507 p.

Sokal, R.R. and F.J. Rohlf. 1981. Biometry 2nd ed. W.H. Freeman and Company, San Francisco. 859 p.

Sumner,F.H., and O.R.Smith.1939.A biologial study of the effect of mining debris and hydraulic mining on fish life in the Yuba and American Rivers, California. U.S. 
District Engineers Office, Sacramento, Calif. Stanford Univer.,Calif. 51 p. cited in Cordone, A.J. and D.W.Kelly.1961.The influences of inorganic sediment on the aquatic life of streams. Calif. Fish and Game. 47:189-228.

Terhune,L.D.B. 1958. The Mark VI groundwater standpipe for measuring seepage through salmon spawning gravel. J.Can.Fish. Bd. 15:1027-1063.

Thomas, J. 1982. Personnal communication. November 15, 1982.

Thornton, M. 1979. Dredging for Gold, the Gold Miners Handbook. Keene Industies, Northridge, CA., 243 p.

Warner, K. and I.R. Porter. 1960. Experimental improvement of a bulldozed trout stream in northern Maine. Trans. Am. Fish Soc. 89:59-63.

Welton,J.S. and M.Ladle. 1979. Two sediment trap designs for use in small rivers and streams. Limnol. Ocean. 24:588592. 


$$
\text { APPEN+DIX A = }
$$

WATER QUALITY

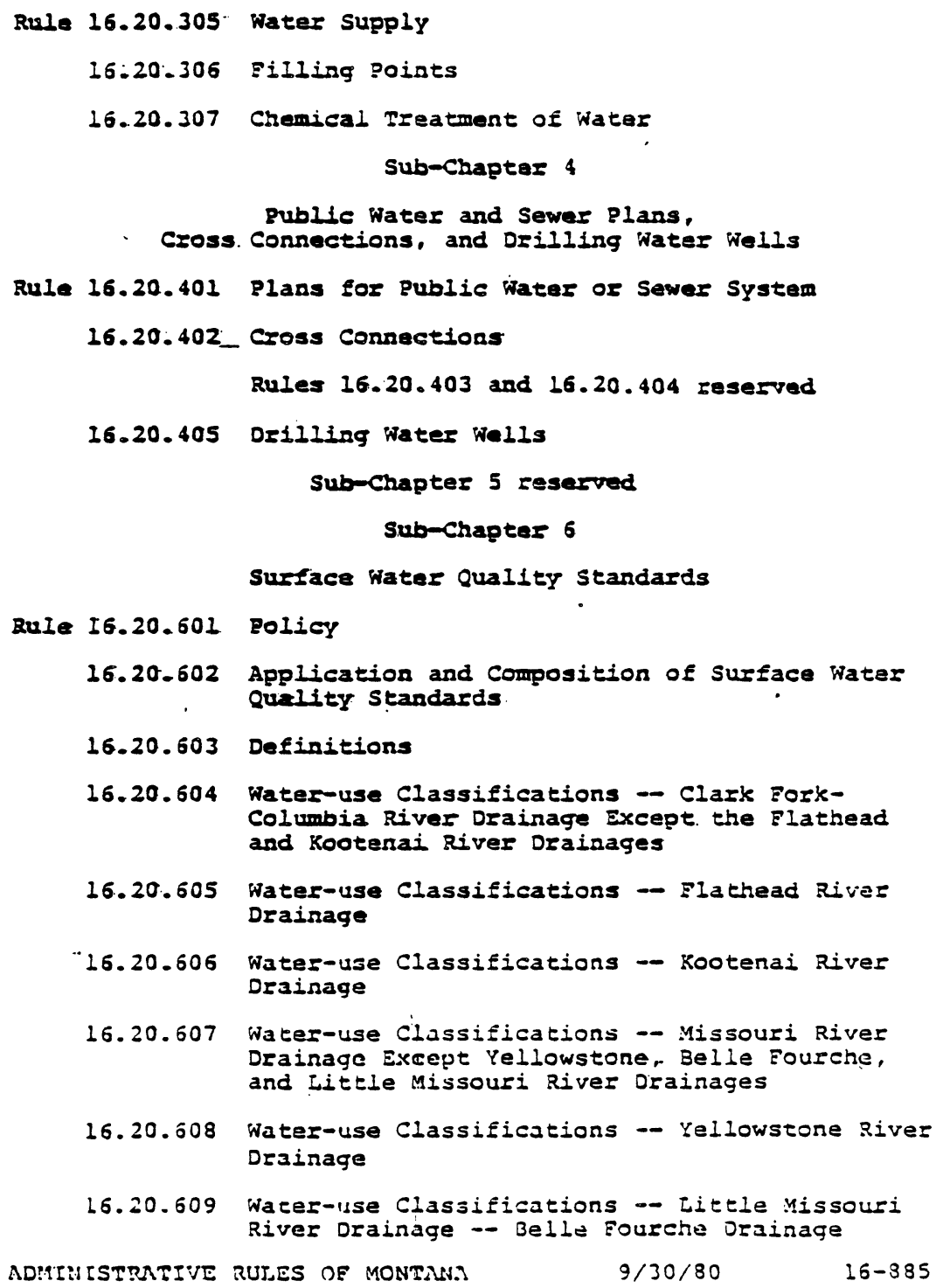




\section{APPENDIX A \\ WATER QUNEITY}

Sub-Chapters 7 and 8 reserved

Sub-Chapter 9

Montana Pollutant Discharge Elimination System (MPDES) Permit

Rule 16.20.901 Purpose

16.20.902 Definitions

Rule 16.20 .903 reserved 
(6) "Geometric mean" means the value obtained by taking the Nth soot of the product of the measured values where zero values for measured values are taken to be the detection limite.

(7) "Intermittent stream" means a stream or reach of a stream that is below the local water table for at least some part of the year, and obtains its flow from both surface sunoff and ground water discharge.

(8) "Mixing zone" means the area of a water body contiguous to an effluent. with characteristics qualitatively or quantitatively different from those of the receiving water. The mixing zone is a place where effluent and receiving water mix and not a place where effluents are treated. Water quality standards do not apply in the mixing 20ne for those parameters. reguilated by a MPDES or NPDES permit.

(9) "IPDEs" means the Montana PolIutant Discharge

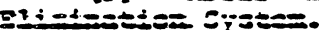

(I0) "NPDES" means the National Bollutant Discharge Elimination System.

(11) "Naturally occursing" means conditions or material present from ranoff or percolation over which wan has no control or from developed land where all reasonable land. soil and water conservation practices have been applied. Conditions resulting from the reasonable operation of dams in. existence as of July 1. 1971 are natural.

(I2) "Nonpoizt source" means the source of pollutanits which originates Erom diffuse runoff, seopage, drainage, or infileration

(13) "Pestictde" means. insecticides, herbicides, zodenticides, fungicides or any substance or mixture of substances intended for preventing, destroying, controlling, repelling, altering life processes, or mitigating any insects, rodents, nematodes, fungi, weeds and other forms of plant or animal bife.

(14) "Pollutants" means sewage, industrial wastes and other wastes as defined in sections $75-5-103(1) \cdot(2)(3)$. MCA.

(15.) "Sediment" means solid material settled fron suspension in a liquid; mineral or organic solid material that is being transported or has been moved from its site of origin by air, water of ice and has come to rest on the earth's surface, either above or below sea level; or inorganic or orfanic particles originating from weathering, chemical precipitation or biological activity.

(16) "Settleable solids" means inorganic or organic particles that are being transported or have been transported by water from the site or sites of origin and are settled or. are capable of being settled from suspension.

(17) "Sewer" means a pipe or conduit that carries wastewater or drainage water. 
(i) Fred Burr Lake and headwaters from souree to the outlet uf the lake (Philipsbures

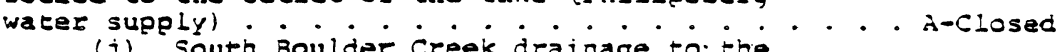
(j) South Boulder Creek drainage to the

Philipsburg water supply intake . . . . . . . A-1

(k) Rattlesnake drainage to the Missoula

water supply intake. . . . . . . . . . . . A-closed

(1) Packer and Silver Creek drainage

(tributaries to the St. Regis River) to the

Saltese water supply intake . . . . . . . . . . A-1

(m) Ashley Creek drainage to the rhompson

Falls water supply intake ............. A-Closed

(a) Pilgrim Creek drainage to the Noxon

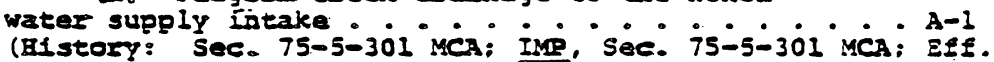

12/31/72; AMD, EEf...11/4/73; AMD, EEF. 9/5/74; AMD, 1980 MAR

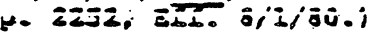

16.20.605 WATER-OSE CIASSIFICATIONS -- FLATHEAD RIVER

DRATAGE The water-use classifications adopted for the

Flathead River are as follows:

(1) Flathead River drainage above Flathead

lake except waters listed in subsections (1) (a)

through (1) (g) Essex Creek drairage to the Essex water $\because \mathrm{B}^{1}$

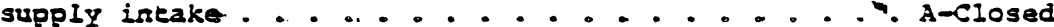

(b) Stillwater River (mainstem) from Logan

creek to the Elathead River . . . . . . . . . . B-2

(c) Whitefish Lake and its tributaries .... A-1

(d) Whitefish River (mainstem) from the

outlet of Whitafish lake to the Stillwater River . . B-2

(e) Easkill Creek drainage to the Whitefish

water supply intake ............... . $^{-1}$

(f) Asthley Creek (mainstem) from Smith Lake

to bridge crossing on the airport road about one

mile south of kalispell. . . . . B-2

(g) Ashley Creek (mainstem) from bridge

crossiny on airport road to the Flathead River . . . C-2

(2) Elathead lake and its tributaries from

Flatheac River inlet to U.S. Highway 93 bridge at

polion except Swan River and portions of tellroaring

Creek as listed in subsections (2) (a) through (2) (c)

but including Swan lake proper and Lake Mafy Ronan

proper . . . . . . . . . . . . . . A-1

(a) Swan River drainage (except Swan lake

proper) * B-1

(b) Heilroaring Creek drainage to the

polson water supply intake . . . . . . . . . . A-Closed

(c) Remainder of Hellroaring Ereek drainage. . B-l 
(1) Missouri River drainage to and including the Sun River drainage except tributaries listed 
(ii) Musselshell River drainage below Deadman's Basin diversion canal above shawmut except portions of Careless. Swimming Woman, Flatwillow and south willow Creek drainages

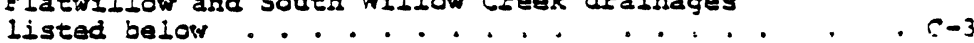
(iii) Careless and swiming woman Creek

drainage above theif confluence north of Ryegate . . B-1 (iv) Flatwillow Creek drainage above U.S.

uighway 87 crossing south of Grassrange......... B-2 (v) South willow Creek irainage above

county soad bridge in TION, R24E. Section 7..... B-1 (6) Missouri River drainage from Fort

Peck Dam to the Milk River ... . . . . . . . . 8-2 (7) Milk River drainage Erom source lor

Erom the Glacter National Bark Boundary) to

the International Boundary ............ 8-1 (8) Milk River drainage srom the Inter-

national Boundary to the Missourt River except

the tributaries listed in subsections (8) (a)

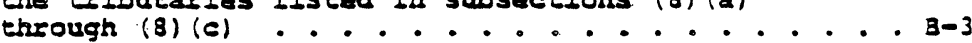

(a) Big Sandy creek drairage to jown of

Big Sandy infiltration wells .......... B-I

(b) Beaver. Ifttle Box Elder and Clear

Creek drainage (near Eavre) . . . . . . . . . B-1 (c) People's Creek drainage to and in-

cluding the South Fork of People's Creek drainage. . B-1

(g) Missouri RIver drainage Erom Milk

River to North Dakota boundary except waters

listed in subsections $(9)(a)$ through $(9)(d)$. . . : $c-3$

(a) Missouri River (mainstem) from Milk

River to North Dakota boundary . . . . . . . B-3

(b) Wolf Creek drainage near Wolf point: : : $3-2$

(c) intelope Creek drainage near Antelope: : B-3

(d) Poplar River drainage . . . . . . . B-2

(History: Sec. 75-5-301 MCA; IMP, Sec. 75-5-301 MCA; Eff. 12/31/72; AMD, EEf. 11/4/73; AND, EEf. 9/5/74; AMD, 1980 MAR p. 2252, EFE. 8/1/80.)

16.20.608 WATER-USE CLASSIFICATION - Y YILOWSTONE RIVER DRAINACE The water-use Classifications adopted 50r the

Yellowstone River are as follows:

(1) Yellowstone River drainage to the Laurel

water supply intake. . . . . . . . . . . . . . . B-1

(2) Yellowstone River drainage from the

Laurel wacer supoly intake to the Billings water

supply incake except the tributaries listed in

subsections $(2)(a)$ and $(2)(b)$. . . . . . . . . . $3-2$

(a) Clarks rork Yellowstone River drainage

Erom source to the wyoming state line and Erom

16-942 $9 / 30 / 80 \quad$ ADMINISTPATIVE RUIES OF MONTANA 
16.20.610 WATER-USE CTASSIFICATIONS -- HUDSON BAY DRAINAGE The water-use classifications for the Hudson jay drainage are:

(I) All waters outside Glacier National

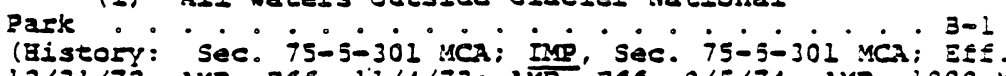
12/31/72; AMD. EEE. 11/4/73; AMD. EEf. 9/5/74; AMD, 1980 MAR P. 2252, EIE. 8/1/80.1

16.20.611 WATER-USE CTASSIFICAIIONS - NATIONAL PARK, WIIDERNESS AND PRIMITIVE AREA WATERS The water-Use classiFications for all national park, wilderness and primitive area waters are as follows:

(1) All waters even if classifications

listed in ARM 16.20.604 through ARM 16.20 .610

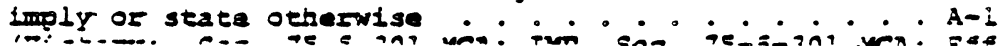

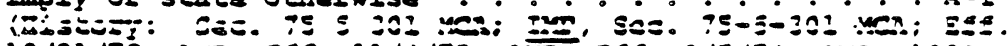

12/31/72; AMD, EEf. 11/4/73; AMD. EEf. 9/5/74; AMD, 1980 :IAR

p. 2252, EEE. 8/1/80.)

Rules 16.20 .612 elrough 16.20 .614 seserved

NEXT PAGE IS $16-949$

16-?t4 9/30/30 ADMINISTPATTVE RLESS JE MONTAMA 
16.20.617 A-1 CASSIFICATION (1) Waters classified A-1 are suivable for drinking, culinary and food grocessing purposes after conventional treatment for semoval of naturaily present impurities.

(2) Water quality must be suitable for bathing, swimming and fecseation: groweh and propagation of galmonid fishes and associated aquatic life, waterfowl and furbearers; and agrieultural and incustrial water supply.

(3) For watars classified $\mathrm{A}-\mathrm{l}$ the following specific water quality standards shall not be violated by any person: (a) The geometric mean number of organisms in the coliform group must not exceed 50 per 100 milliliters if resulting from domestic sewage.

(b) Dissolved oxygen concentration must not be reduced below 7.0 milligrams per biter.

(c) Induced variation of hydrogen ion concentration (ph)

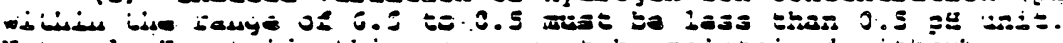
Natural pll outsidi this. Fange must be maintained without change. Natural pa above 7.0 must be maintained above 7.0 .

(d) No increase above naturally occurring turbidity is allowed except as permittad in ARM 16.20 .631 ehrough 16.20 .635 and $A$ Ry 16.20 .641 and 16.20 .642 .

(e) $A$ to $F$ maximum increase above naturally occurzing water temperature is allowed withis the range of $32^{\circ} \mathrm{F}$ to $66^{\circ}$; ; within the saturally occurring range of $66^{\circ} \mathrm{F}$ to $66.5^{\circ}$ E, ho discharge is allowed which will cause the water temperature to exceed 67. $\mathrm{F}$; and where the naturaliy ocsursisg water tomperature is $66.5^{\circ} \mathrm{g}$ or greater, the maximum allowable increase in water temperature is $0.5^{\circ}$ F. A $2^{\circ}$ E per hour maximum decrease below naturally occurring water temperature is 3 llowed when the water temperature is above $55^{\circ} \vec{z}$, and a $2^{\circ}$ F maximum decrease below naturally occurring water eemperature is allowed within the range of $55^{\circ} \mathrm{F}$ to $32^{\circ} \mathrm{F}$.

(E) No increases are allowed above naturaliy occursing concentrations of sediment, seteleable solids, oils, or floating solids, which will or are bikely to create a nuisance or render the waters harmeul, detrimental, or injurious to public health, fecreation, safety, welfare, livestock, wild animals, birds, fish, or other wildilifa.

(g) True color must not be increased more than two units above naturally occurring color.

(h) Concentrations of toxic or other deleterious substances which would remain in the water after conventional water tesutment aust not exceed the maximum contaminant levels set sorth in the 1975 National Interim Primary orinking ivacer Standarda (40 GrR Part 141) or subseruent zevisions of she 1979 llacional secondary Orinking hater standards ( 40 CFR ?are 143) of jubsequent revisions. The maximum allowable concantrutions of toxic of deleterious substances 3130 nust not 
range of $32^{\circ}$ F to $65^{\circ} \mathrm{F}$; within the naturally occurzing range of $65^{\circ} \mathrm{F}$ to $66.5^{\circ} \mathrm{F}$, no discharge is allowed which will cause the water temperature to exceed $67^{\circ} F_{i}$ and where the saruratiy occurring water temperature is $66.5^{\circ}$ F or greater, the maxisum allowable increase in water temperature is $0.5^{\circ} \mathrm{F}$.

(E) No increases are allowed above nacuraity occurzine concentrations of sediment, settleable solids, oils, or floating solids, which will or are likely to create a nuisance of render the waters harmful, detrimental, or injurious to public

health, recreation, safety, welfare, livestock, wild animals, birds, fish, or other wildife.

(g) Juve color must not be increased more than five units above naturally occurring color.

(h) Concentrations of toxic or other deleterious substances which would jemain is the water after conventional water ereatment must not exceed the maximum contaminant levels

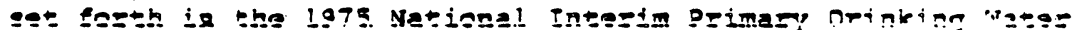
Standards (40 GFR Part 141) or subsequene fevisions or the 1979 National Secondary Drinking Water Standards (40 CFR Part 143) or subsequent zovisions. The maximum allowable concentsations of toxie or deleterious substances also must not exceed acute or chronic problem levels as revealed by bio-assay of other methods. The values listed in Quality Criteria for Water publistred by the Office of Water and Bazardous Materials, EFA, Washington. D.C. (The Red Book) shall.be used as a guide to determine problem levels unless bocal conditions make these values inappropriate. In accordance with section 75-5-306 (I) MCA. It is not necsssary that wastes be treated to a purer condition than the natural condition of the receiving water. (Bistory: Sec. 75-5-301 MCA; IMP, Sec. 75-5-301 MCA; EEE. 12/31/72; AMD, EfE. 11/4/73; AMD, Eff. 9/5/74; AMD, 1980 MAR P. 2252, EE⿱乛. 8/1/80.)

16.20.619 8-2 CLASSIFICRIION (1) waters Classified 3-2 are suifuble for drinking, culinary and sood processing pus=poses, after conventional treatment; bathing, swimming and recrastion: groweh and marginal propagation of salmonid fishes and associated aquatic life, wateffow 1 and surbearess: and $a g r i e u l t u r a l$ and industrial water supply.

(2) For waters classified $3-2$ the following soecisic water guality standaris shall not be violated by any person: (a) The geomeric mean number of organisms in tie teca: coliform group must not exceed 200 per 100 milliliters, nor ars 10 percent of the cotal samples during any 30 -day period to sirccad 400 Eacal coliforms per 100 milliliters.

(b) Dissolved uxygen concentzation nust not be zeducal below 7.0 miligrams per liter from October l enrough june nor velow 6.0 milligrans per liter srom June 2 through Seprember 30 . 
16.20.620 B-3 CIASSIFICATION (1) Waters classified 5-3 are suifable for drinking. Culinary and food processing purposes, after conventional treatment; bathing, swimming and fecreation; growth and propagation of non-galmonid sishes and associated aquatic life, watertowl and furbearers; and agr:cultural and industrial water supply.

(2) FOr watars classified B-3 the following specific water quality standards shall not be violated by any person: (3) The geometic mean number of ofganisms in the Escal coliform group must not exceed 200 per 100 milliliters, nor are 10 percent of the total samples during any 30 -day period to eseceed 400 fecal coliforms per 100 milidilitsrs.

(b) Dissolved oxygen concentration must not be reduced below 5.0 nilligrams per liter.

(c) Inducad variation of hydrogen ion concentration (pF) within the zange of 6.5 eo 9.0 must be less than 0.5 ph unit.

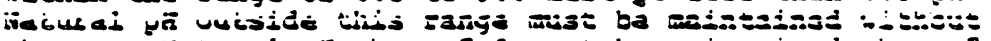
change. Natural pa above 7.0 must be maintained above 7.0 .

(d) The maximum allowable increase above naturally occurring turbidity is 10 nephelometrie turbidity units except as permitted in ARM 16.20 .631 through 16.20 .635 and ARM 16.20 .641 and 16.20 .642 .

(e) A $3^{\circ}$ E maximum increase above naturally oceursing water temperature is allowed within the range of $32^{\circ} \mathrm{g}$ to $77^{\circ}$ F: within the naturally oceurring range of $77^{\circ} \mathrm{E}$ to $79^{\circ} .5^{\circ} \mathrm{F}$, no thermal ilscharge is allowed which will cause the water temperature to exceed $80^{\circ} \mathrm{F}$; and where the naturally occursing water temperature is $79.5^{\circ}$ F or greater, the maximum allowable increase in water temperature is $0.5^{\circ} \mathrm{F}$. A $2^{\circ} \mathrm{F}$ per hour maximum decrease below naturally occurring water temperature is allowed when the water temperature is above $55^{\circ} ?$, and 3 2. I maximum decrease below naturally occurring vater lemperature is allowed within the range of $55^{\circ} \mathrm{E}$ to $32^{\circ} \mathrm{E}$.

(i) These allowable increases apply to all waters in the state classified $3-3$, except for the mainstem of the Yellowstone River Efom the Bilinings water supply intake to the water diversion at Intake, where a $3^{\circ} \geq$ maximum increase above naturally occursing water temperature is allowed witiln the rangle of $32^{\circ}$ E to $79^{\circ} \mathrm{F}$; within the sange of $79^{\circ} F$ to $81.5^{\circ} \mathrm{E}$, no ehermal discharge is allowed which will eause the water comporature to exceed $32^{\circ} \mathrm{F}$; and where the nacural-!" occurzing water temperature is $31^{\circ} .5^{\circ}$ E or greater, the maismum allowphle increase in water temperature is $0.5^{\circ} \mathrm{F}$.

(ii) From the water diversion at Intake to the vorth D.akota seated line, $3^{\circ} \varepsilon$ ma:kimum incrcase above natural $b y$ occusfing water temperaburc is allowed within the sange of $32^{\circ}$ F to $32^{\circ} \mathrm{F}$; within the eange of $32^{\circ} \mathrm{F}$ to $34.5^{\circ} \mathrm{E}$, no thermal discharge is allnwed which will cause the water remperzture to exceed $85^{\circ} \mathrm{F}$; and where the naturaliy ocsurzing 
except as permitted in ARM 16.20.631 through 16.20 .635 and ARM 16.20 .641 and 16.20 .642 .

(e) A I0 E maximum increase above naturally occursing water temperature is allowed within the range of $32^{\circ} \equiv=0$ $66^{\circ} \mathrm{F}$; within the haturally occurring range of $66^{\circ} \mathrm{Z}$ to $66.5^{\circ} \mathrm{F}$, no discharge is allowed which will cause the water temperature to exceed $67^{\circ} F^{\circ}$, and where the naturally occursing water temperature is $66.5^{\circ}$ ? or greater, the maximum allowable increase in water temperature is $0.5^{\circ}$ F. A $2^{\circ} \bar{F}$ per hour maximum decrease below naturally occurring water temperature is 3llowed when the water temperature is above $55^{\circ} \xi$, and a 2. F maximum decrease below naturally oceurring water temperature is allowed within the range of $55^{\circ} \mathrm{F}$ to $32^{\circ} \mathrm{F}$.

(f) No increases are allowed above naturally occurzing concentrations of sediment, settleable solids, oils, or Eloating solids. which will or are likely to eroate a nuisance or

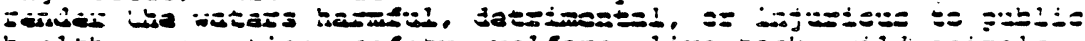
healts, Iscrestion, safety, welfars, livestock, wild anifals, bieds, fish. or other wildilfe.

(g) True color must not be increased more than five units above naturally occursing color.

(h) Concentrations of toxil or jeletsious substances must not exceed levels which render the waters harmiul, detrimental of injurious to public health. The maximum a llowable concentrations of toxic or deleterious substances also must not exceed acute or chronic problem levels as revealed by bioussay or other methods. The values listed in Qualify Criteria for water published by the office of Water and Hazardous Materials, ERA, Washington, O.C. (The Red 800k) shall be used as a guide to determine problem levels unless local conditions make these values inappropilate. In accordance with section 75-5-306(1), MCA, it is not recessary that wastes be treated to a purer condition than tie natural condition of the receiving water.

(i) In the segment of the Clark Fork River classified $6-1$. the parameter limits set forth below apoly sather than the hinits listed for these parameters in the ked Book:

\section{Parzmeter}

Total copper

Total zinc

Toeal ison

Toezl leas

Total cadmium

Toest arsenic

Tocal mercury
Marimun Instantansous Concenezition

$$
\text { प्रg/l }
$$

90

300

100

50

(History: Sec. 75-5-301 MCA; LMP, Sec. 75-5-301 MCA; Es: 12/31,72: AMD, EEE. 11/4/73; AMD, EEE. 9/5/74; AMD, L980 :AR อ. 2252. Eह5. $3 / 2 / 30.1$ 
shall be used as a guide to determine problem levels unless local conditions make these values inappropriate. In acsordance with section 75-5-306(1), MCl, it is not necessafy that wastes be treated to a purer condition than the natural condition of the receiving water.

(i) In the sequent of tre Liark Fork River classified 6-2, the parameter limits set forth below apply rather than the limits listed for these parameters in the Red Book:

Parameres

Maximum Instantaneous Concentzation

\begin{tabular}{lr} 
Total copper & \multicolumn{1}{c}{90} \\
Total zinc & 300 \\
Total iron & 2200 \\
Total lead & 100 \\
Total cadmium & 10 \\
Total arsenic & 50 \\
Total mercury & 1
\end{tabular}

(Bistory: Sec. 75-5-301 MCA; IMP, Sec. 75-5-301 MCA; EEF. 12/31/72; AMD. EEF. 11/4/73; AMD, EEE. 9/5/74; AMD, 1980 MAR p. 2252, Eझः० 8/1/80.)

$16.20 .623 \mathrm{E}$ CASSIFICATION (I) waters classified $\Xi$ are suifable for agriculeural and industrial water uses ofher than food processing.

(2) For waters classified $\mathrm{I}$ the following specific water quality standards shall not be violatad by any person:

(a) The geometic mean number of organisms in the secal coliforta group must not exceed 200 per 100 milliliters, sor are 10 percent of the total samples during any 30-day period to exceed 400 fecal coliforms per 100 arililitiers.

(b) Dissolved oxyger concentrution muse not be seduced below 3.0 milliggrams per liter.

(c) Bydrogen ion concentration muse be maintained within the eange of 6.5 to 9.5 .

(d) No increase in naturally occurring turbidity is allowed which will or is likely to create a nuisance or zender the waters harmil, detrimental, of injurious to public healis, fecreation, safety, welfare, livestock, wild animals, bizds,

Eish, or other wildiffe.

(e) No increase in naturally occurring temperature is a lluwred which will or is likely to create a nuisance or rendez tre waters harmful, detrimental, or injurious to public heal=: fecroation, safery, welfare, livestock, wild animals, bi=ds, fish, or other wildilife.

(F) No increases above nacurally occuszing concentzations of sedimant and settleable solids, oils, or floating sobids are allowed which will or are bikely to create 3. nuisance or eender the waters harmful, detrimental, or injurious so publis

L6-953 9/30,80 ADMINISTRATIV RULES OE MONTAHA 
(E) No increases are allowed above naturally occurging concentrations of sediment, settleable solids, oils or floaring solics, which will or are likely to create a nuisance of zender the waters harmiul, detrimental, of injurious to subi:s health. zecreation, safety, welfare, livestock, wild animals, biris, fish, or orher wilatire.

(g) True color must not be increased more than sive units above naturally oceurring color.

(h) Concentrations of toxic or other deleterious subseances must not exceed levels which render the waters hamEul, derrimental or injurious to public health. The maximus allowable concentrations of toxic or deleterious substancs also must not exceed acute or chronic problem levels as zevealed by bio-3ssay of other methods. The values listed in Quality Critaria for Water published by the office of water and Bazardous Materials, EPA. Wastington. D.C. (The Red Book)

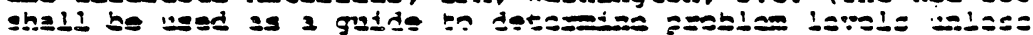
local conditions make these values laappropriate. In accordance with section 75-5-306(1). MCA, it is not necessary that wastes be ereated to a purer condition than the natural condition of the secaiving water. (IIstory: Sec. 75-5-301 MCA IMP, Sec. 75-5-301 MCA; Eff. 12/31/72; AMD, Eff. 11/4/73;

AMD', Eff. 9/5/74; AMD. $1980 \mathrm{MAR}$ P. 2252 . ElE. 8/1/80.)

Rules 16.20 .625 ebrough 16.20 .630 seserred

NEXT PAGE IS $16-965$ 
manner to minimize harmful effects. New water impoundments muse be designed to provide temperature variations in discharging water that maintain or enhance the existing propagating fishefy and associated aquatil life. is a guide, the following temperature variations are recommended: Continuousiy iess irian $\dot{f}=\mid F$ during the months of january and Eebruary, and continuously greater ehan $44^{\circ}$ E during the months of June ebrough september. (History: Sec.75-5-301 MCA; IMP, SEC. 75-5-301 MCA; EEE. 12/31/72; AMD, EEE. 11/4/73; AMD. EEE. 9/5/74: AMD, 1980 MAR p. 2252, EEf. 8/1/80.)

16.20 .633 PROEIBIrIONS (I) State surface waters must be free from substances ateributable to municipal, industrial. agriculeural practices or other discharges that will:

(a) Settle to form objectionable sludge deposits or emulsions beneath the surface of the water or upon adjoining shnpolinas?

(b) Create floating debris, scum, a visible oil silm lor be present in concentrations at of is excess of $10 \mathrm{milli}$ grams per literl or globules of grease or other floating matezials:

(c) produce odors, colors or other conditions as to which creace a ruisance or render undesirable tastes to fish Elesin of make isis inedible:

(d) Create concentrations of combinations of materials which are toxic or harmful to human, asimal, plant or aguatic life: and life.

(e) Create conditions which produce undesifable aquatic

(2) No wastes may be discharged and no activities conducted such ehat the wastes or activities, either alone or in combination with other wastes or activities, will viobate, or can reasonably be expected to violate, any of the standards.

(3) No wastes are to be discharged and no activities conducted which, either alone or in combination with other wastes or activities, will cause violations of surface watas quality standards: provided, a short term exemption from a sufface water guality standard may be authorized by the dipartnont under the following conditions:

(a) If the Deparement of Bish, Nildiffe and parks =aViw:; a short-torm construction or hydraulic project under section 76-j-50l es sea., MCA. or section 75-7-10l et sed. MCh, an increase $\overline{1 n}$ eurbidity caused by the project e:iempt from the applicable turbidity stancard unless the duparement is advised by the Deparenent of Eish, wildijEe and parks that the project may gesult in a significant incrajse in turbidiey. If the department is advised tiat lae projece may cause 3 significant increase in eurbidity, tie 
(6) Until such time as mirimum stream flows are established for dewatered streams, the minimum treatment requi=ements for discharges to dewatered receiving streams must be no less than the ninimum treatment zequirements set forth in ARM $16.20 .631(2)$ and $(3)$.

(7) Treatment requirements for discharges to ephemerastreams nust be no less than the nisimum treatment reguifements set forth in ARM $16.20 .631(2)$ and (3). Ephemeral streams ars subject to ARM 16.20 .631 through 16.20 .635 and AR4 16.20 .641 and 16.20 .642 but not to the specific water quabity resndards of ARM 16.20 .615 through 16.20 .624 .

(8) Pollution fasultiog from storm dralnage, storm sewer discharges, and non-point sources, including ifrigation oractices, foad buildiag, construction, logging practices, overgrazing and other practices must be eliminated or minimized as ordersd by the department.

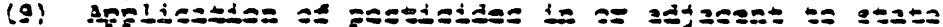
surface waters must be is compliance with the labeled difection, and in accordance with provisions of the vontana Pesticidus Act (Title 80, Chaptar 8, MCa) and the Federal Envizormantal Peseicides Contzol Act (7 O.S.C. $136 \mathrm{et}$ seg. (Supp. 1973) as amended). Excess pesticides and pesti lide contriners must not be disposed of in a manner of in a location where they are likely to pollute surface waters. (10) No pollutants may be discharged and no activities way be conducted which, either alone or in combination with other wastes or activities, fesult id the total dissolved gas prossure relative to the water surfacs exceeding 110 percent of sacuration.

(I1) On all public water supply watersheds, detailed plans and specifications for the construction and operation of logging roads will be submitred to the departent sor its approval as required by Title 75, Chapter 6, MCA. (Histor?: Sec. 75-5-301 MCA: IMP, Sec. 75-5-301 XCA; Eff. 12/31/72; AMD, EEE. 11/4/73; AMD, EEf. 9/5/74; AMD, 1980 MAR P. 2252, EEF. $8 / 3 / 80.1$

16.20 .634 MIXING ZONE Discharges to surface waters may be entifled 3 mising zone which will have a minimum imoact on surface valor quality, as determined by the department. (History: Sec. 75-5-301 MCA; IMP, Sec. 75-5-301 MCA; EE 12/31/72; NMD, EEE. 11/4/73; AMD, EEE. 9/5/74; AMD, L980 VIAR p. 2252, EE. $8 / 1 / 30.1$ 
confined bioassays. Al1 bioassay methods and spectes selections muse be appenved by the department. (llistory: sec.

75-5-301 MCA: IMP, SeC. 75-5-301 MCA; EfE. 12/31/72; AMD.

E5E. 11/4/73; MMD, ESE. 9/5/74; AMD, 1980 MAR P. 2252, EE.

$8 / 1 / 80.1$

16.20.643 MIEAL LIMITS IS REPEALED (BISTOIY: SEC. 75-5-301 MCA: IIP, SeC. 75-5-301 MCA; Eff. 12/31/72; AMD, EEf. HI/4/73; FMD. EEf. 9/5/74; AMD. [REP], 1980 MAR P. 2252, Eff. $8 / 1 / 80.1$

NEXI RAGE IS $16-983$ 
MONLANA DEPARTMENT OF FISE, WIIDIIFE AND PARRS

GUIDELINES FOR REVIEN COMAENTS ON

PERUIT APPIICATIONS FOR INSTREAM MINING

Prepared by:

Ecological Services Division and Fisheries Division

INTRODUCTION

These guidelines bave been developed for the use of Department of Fish, Wildlife and Parks personsel in fulfilling the deparment's examination and recommandation responsibilities on permit applications for instream mining proposals. Departmat responsibility for examination and recommadations on proposed profects is found is the Natural streambed and Land Preservation Act of 1975, 75-7-701 sed seg., and the stream Protection Act. 85-5-501, xal et seq. It is clearly stated in these Acts that the state of vontana's policy is to preserve streams in theif natural condition and to keep soil arosion and sedimentation to a minimum after due consideration of relevant factors. Other project review responsibilitiés include those in vontana Surface Water Quality standards, at Section $16.20,633$ (3a). This sequires department review of projects for potantial water grality degradation. In addition, the Fish and Wildlife Coordination Act requises consultation with the department when a stream is modified for any purpose whatsoever by the federal govermment or by any private or public agency under Federal permit or license. The departent also has a general responsibility for the overall welfare of fish and wilditfe of the state under profisions of 87-1-201 $\mathrm{MCA}$.

The damage which has occurred to the bontana stream resource from past mining actipities is obvious in practically all secions of the state, and in some cases this damage is of secent origin. The intent of these guidelises is to meet department responsibilities with the 
joal of preventing immediate or secondary adverse hydraulic change and erosion of streambeds or banks, protecting riparian vegetation, and preventing sediment pollution. for the purpose of preserving the integrity of natural strean systems on which the fish and wildlife zesouree depends.

-In consideration of fulfilling our responsibilities, the department does object to in-stream mining unless a.) mining conforms with the guidelines, b.) it is shown by the miner or the permit issuing agency that such mining will not adversely affect the stream resource

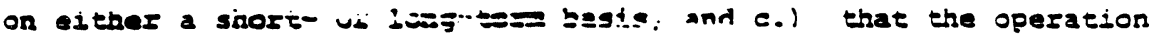
complies with other applicable state and sederal laws. In addition. the departane will not concur is issunace of instream mining permits within any designated N11d. Scenic or Rereational portens of Montana streams, streams withis desigatend vildermess areas, or class I erout (Blu Rsbboa) streame.

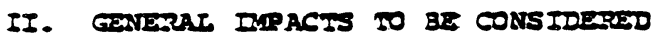

A stream is a complicated systam of loteracting parts, and will Eespond to manipulations within 1 ts watershed. He department is hereis corcerned with altsration of the immediate liparian area of the stream, or the strean itself. Nildilie, as well as Eisheries values, should be considered when making secomendations or decisions on permits. Potential impacts fall into three general categories:

(a) Stream mechanics and morphology

(b) Water guality

(c) Biological populations

In addition, impaces on stream systems are largely dependent on the type or size of equipment utilized for mining, and Einally, the amount of material moved within or removed from the system. 
II. SPECIFIC ARSAS OF CONCERN

The following addresses factors which relate to the stability

and guality of the stream where mining is proposed to occur.

STREAY MECEANICS AND MORPBOLOGY

Certain types of stream matertal are obviously more erodible

than others. Consideration should be given to the potential for

erosion and sediment production when considering permit appli-

cations. Mining activities which affect stream stability include:

Mtaing for Construction Materials

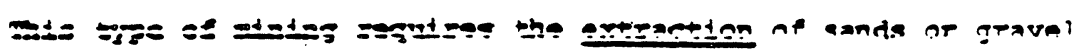

fron the siver system. Dealal of permites for this activity should

be secommended unless. It has been demonstrated that the removal

will facilitate the natural bydrablic function of the stream and

will correct an extsting stream habltat problem. Purther, the need

for an instream source should be demonstrated when terrestrial sources

are available. Stro comiercial need for constraction material usualiy

requires large quantities of material, and may require streambed

discuption over longer pertods of the than mining for personal use,

permits for commercial mining of this frpe in streambeds should not

be agreed to. Permits for construction matertal mining for persona.

use should include conditions to protect fish and wildife values.

Gold Panning and Eand Rockers

kand pansing of gold will be acceptable only is those streams in which it has been provided that material to be panned is not taken from streambanks and ilpartan vegetation is not undercut or destroyed. The use of mechanical washers of any type lother than hand rockers) is not considered to be panning. The maximum amount of material panned per 24-hour period should not exceed 2 cubic

yards. Other guidelines should be considered when panning is proposed. 


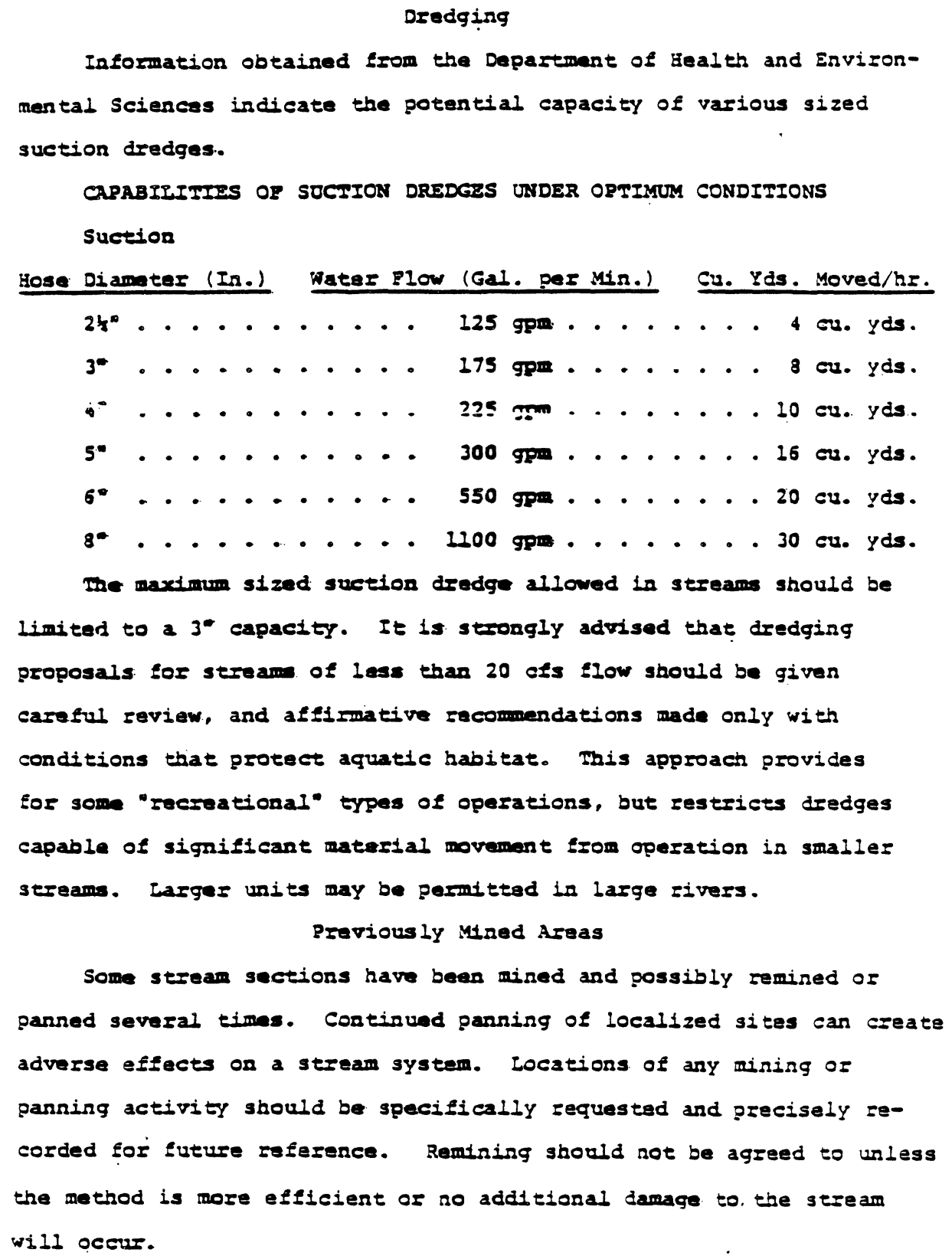


Inseream Mechanical or Sluice Dredging

Departenent personnel should not concur in any dredging proposal

which would take place in such a way that the total streambed or streambanks are destroyed or undercut, either by mining action or by fechanaling of the stream. Such actions are clearly not consistent with state polioy to preserve streams in their natural state.

\section{WATER QUARIMY}

\section{standards compliance}

In Montana Surface Water Quality Standards, Sec. 16.20 .633 (3a)

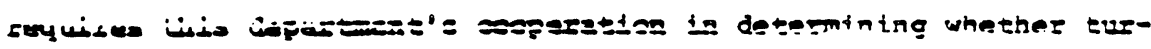
bidity standards wil be violated by stream projects. In addition to this copperation, no permit should be concursed in unless in the coviewtig employe's best judgent all seandards will be wet and. there will be no significant damage to aguete resources. The effact of water withdrawal for places or washing purposes should be considesed as a water grallty problem.

stedsg zone

kixing zones for turbidtty resulting srom mining in streams may be permitedd by thie State Deparmant of Eeal th and Envifonmental Sciences. At the terminal point of the mixing zone, water guality must meet be standard for the steam. which will be either 5 or 10 nephelometric turbidity units (NIO's) is salmonid streams, over that which exists upseream of the miging activity.

Section 75-5-303 (Nondegradation Polify) of the Montana Nater Quality Act states that "... state waters whose existing guality is higher than the established water guality standards be maintained at that high quality unless it has been affimatively demonstrated to the board that a change is justifiable as a result of necessary 


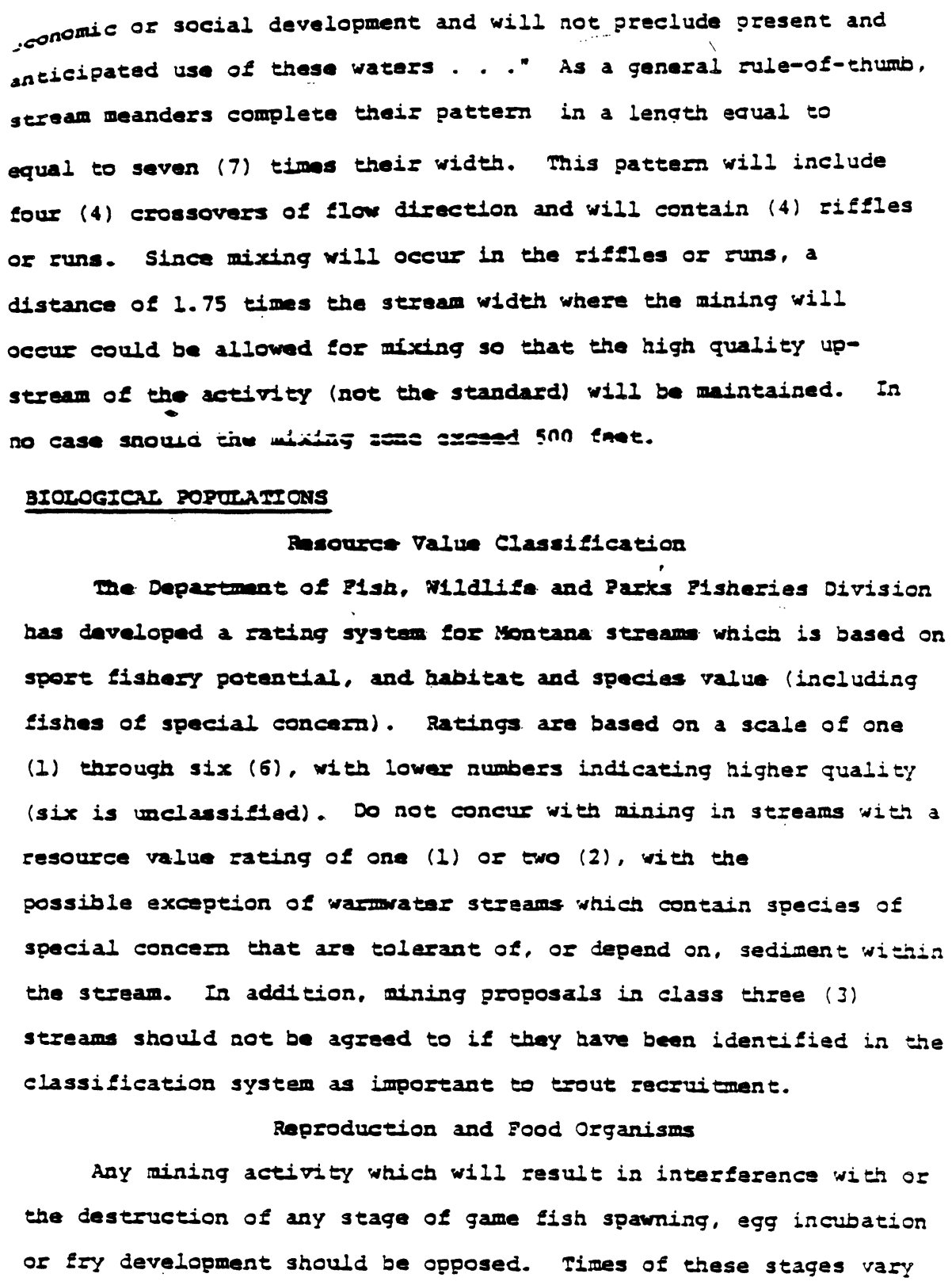




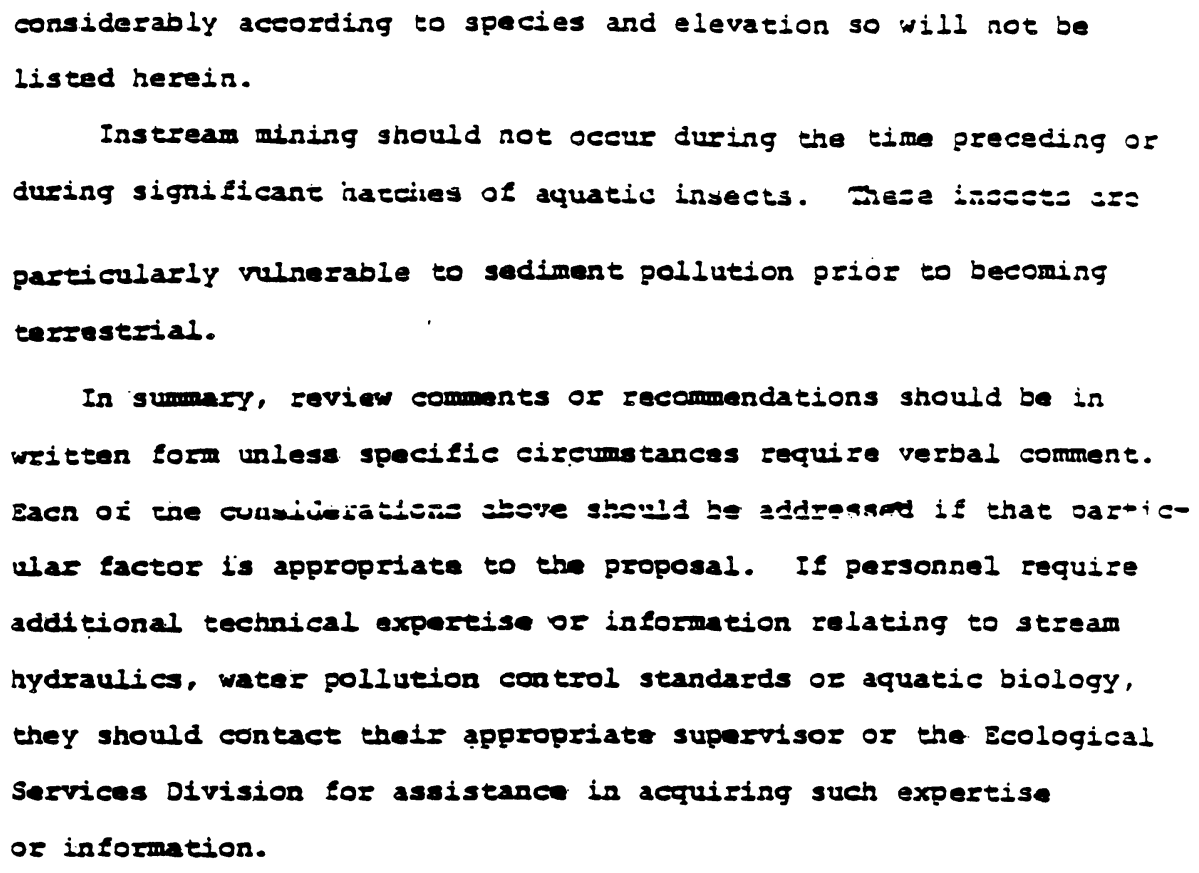




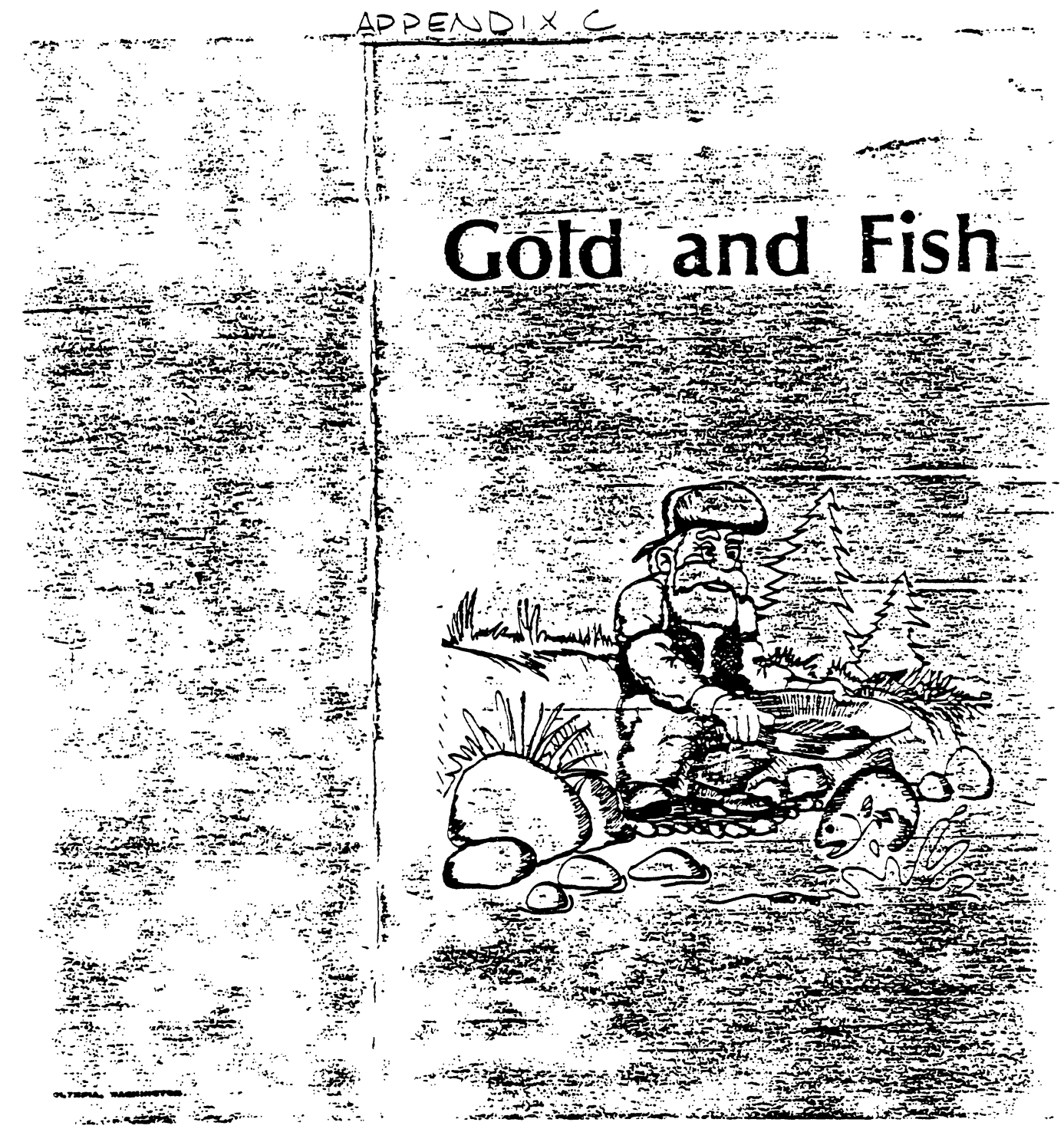




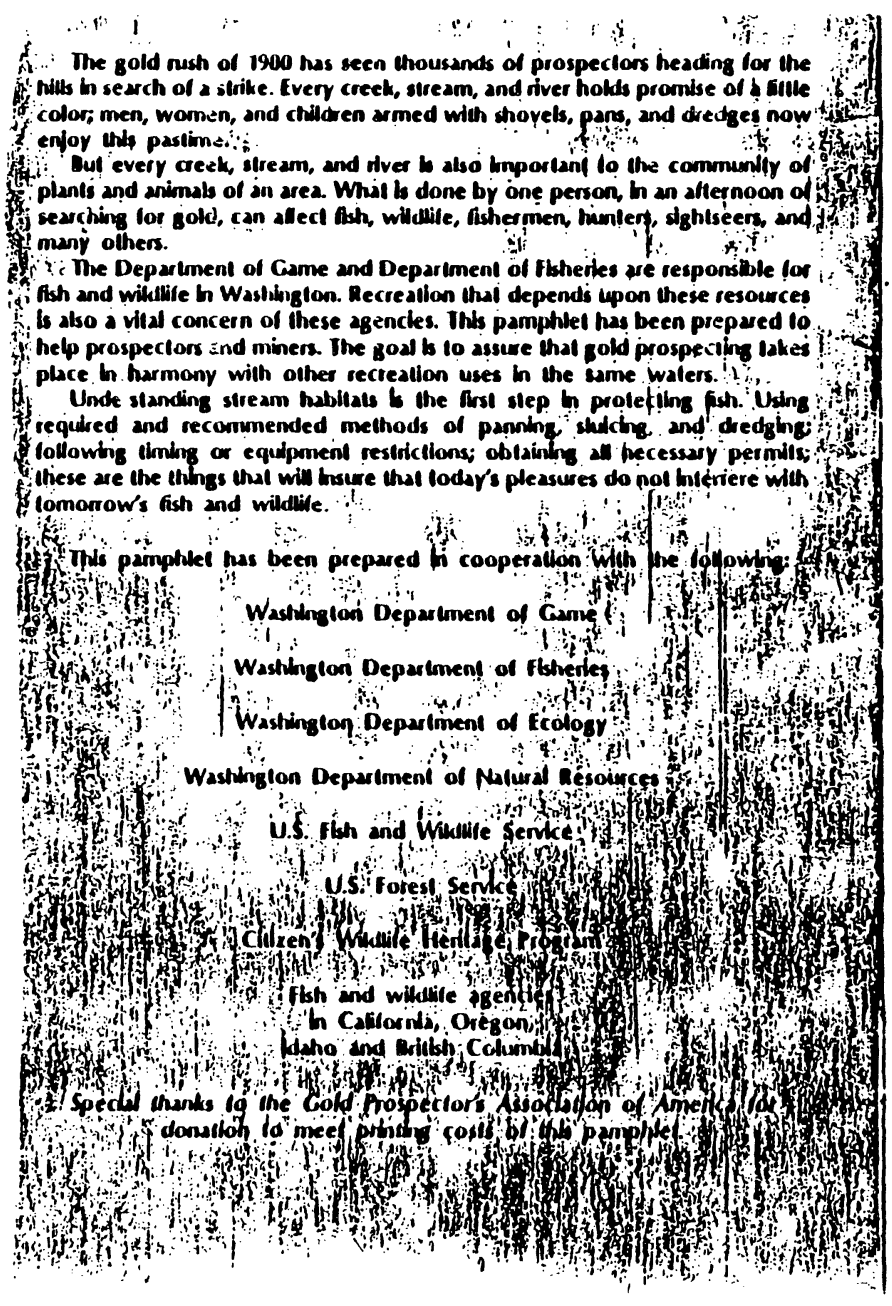

The Stream Environment

The stream environment, or "ecosystem", is composed of living and non-iving elements which interact with one another, each inthencing the other,

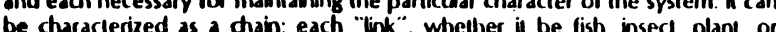
water is vita Disturbance of one part inevitaty attects at others. as a chin is wa stronger than ins weakest link Very oflen we may not be athe 10 immediacly see the resilts of a disturbance; however the kng-term or cumulative impacis can be just as severe.

To understand the stream ecosystem, it is best to examine each of its parts. figure 1 depicis a simple example.

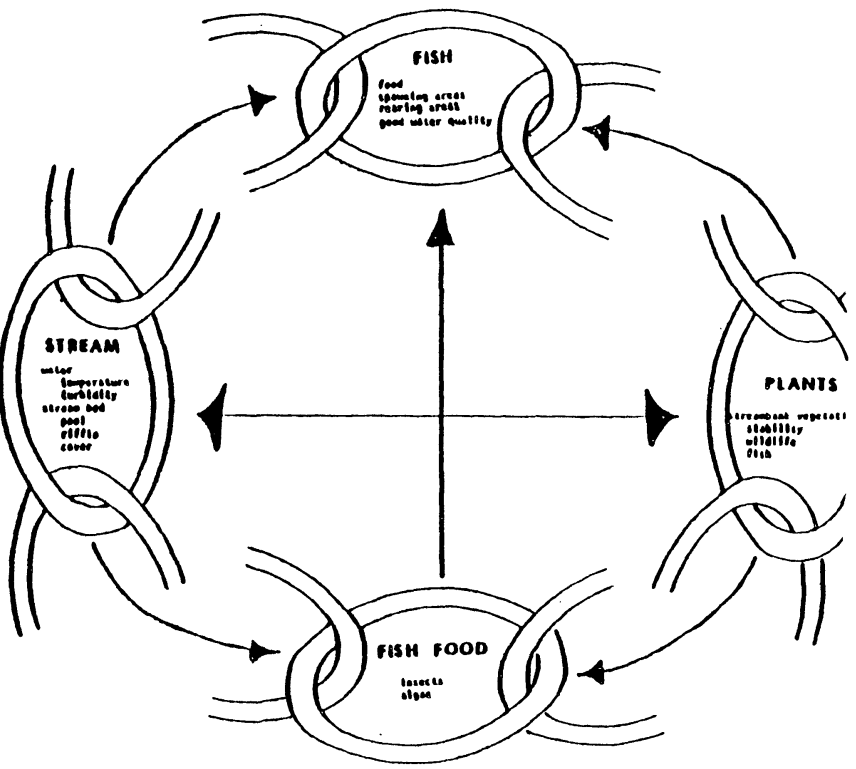

IICURE 1: thats in the stiesm ecosystem chain. A disturbance in one can alleci alt others. 


\section{Slream}

Water

Temperature and iurbicity are probably the Iwo most important water lactors atiecting the lisheries resource. Cool, relatively constant stream qualily. decreasing the ability of lish to wthst and diseases and makking them for more sensive 10 stress. Their atiny 10 leed spawn (reproducel swim or migrale, navigate, escape from predalors, and adapt to changes in their surroundings is reduced

Rurbidity-increased particles of dir and debris suspended in water - can have direct and indirect ellects on stream environmenis. $x$ xcessive amounis can:

Reduce aquatic and underwater plant numbers and kinds through an abrasive action or through a decrease in the amount of light reaching Re bollom of the waler.

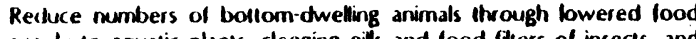
physically har ming insecis

3. Reduce fish mumbers by decreasing lood supplies, damaging gils, making in hard to actually see and calch lood, and ineerrupting spawning.

Excessive amounis of dirt and debris which setlle on the bottom of streams can also affect the total stream system in many ways:

thanging bottonn quality (from gravel io sill

Reduce rumbers of boltonrdwelling animals through less food and less living space as areas between rocks are filled by sith, forcing animals into

Reduce fish living areas by fitting in pools with sediment, or filing in spaces between rocks lorcing smaller fish into current.

tish rumbers from loss of habilat (mumber 3), lowered bollom-dweling food supply (rumber 2). lewer young hish (iny) die to

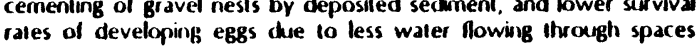
between gravels.

Stream bed

The actual shape of o stream bed is also very important in determining whether the area can support lish, and what uses will te made of in by resident deep areas. (See Figure 2 )

This profide of a iypical stream shows a series of shallow areas (fiffles) and deeper areas (poots) spaccil every five in seven charmel wirthis apart. Rillltes are deeper areas (poots) spaccitevery live in seven charnet wichlis apart. Rins ans of stream in question). less than averape depth. and therefore, are areas of higher water velority Ber ause of the laster, shallower water, riflles are recognized as "white water or turbudent areas of strealins lin most streams the

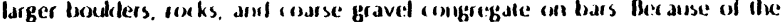

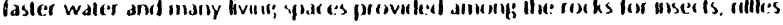

are important food prodkcing areas of streams. Riftles are also important as poowng areas

. With rifles, are streant ateas of deeper, slower water. Under low flow conditions, the water surfaces of pools are generally llat and smooth. Stream bed in pool areas is olten composed of smather rocks. gravet or even sond and shi. decause of the deeper, slower water, pools are live major resting and rearing areas for stream lish.

Cover of these shellered to fish. Removal of large rocks or embedded logs, for example, can reduce the number of pooks either by filling or by changing the direction of stream flow.

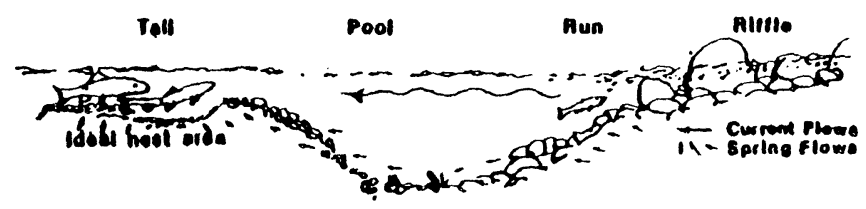

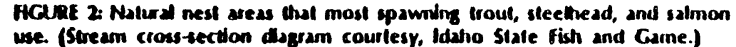

\section{Fish Food}

Fish leed primarity on insects and aquatic planis (algae). Insecis and unallached plants are often drectly destroyed by dredging activities, particiarly by physical cher. that temoves much of the plant lle that is eaten by insecis which live in stream beds. Consequenthy, even though natural drilt may repopudate an area. the foud base

\section{Plants}

Streambank (riparian) vegetation serves many critical functions in the strean) ecosystem (ser: ligure 3):

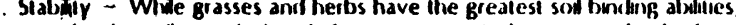
woody (Whinis (in partikctar, their root systems) also protect banks trom

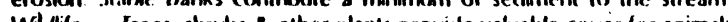

2. Windile - rees, shridss a other planis proville vahuable rover fir animals and allow inc movement hom one pace lo annither Ripariun vepetation bircls and sutull inumenals. 
3. Fish-Strearnside plants contribute protective cover and insects for lish. There appears to be a direct link belween the amount of vegetation and total fish production of a stream. Overhanging brush helps keep water lemperalures from beconing too high in summer, and also protects fish from sunburn which could kit them.

Any activity which disturbs stream bank vegetation can allect lish popudations for many years. Loosening sor around plant roots, for example, may weaken the area sulfienly lo calse as hass du ing the next winters high waler nows or loss. Consequenly, whe he dis

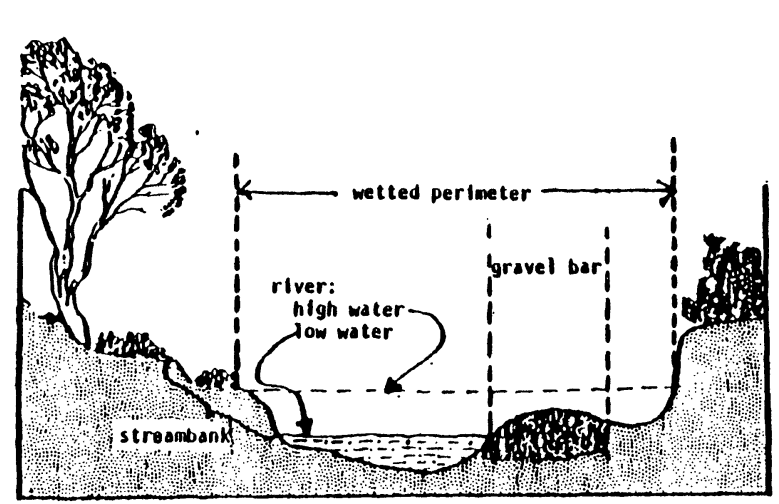

FGURE 3: Iypked stream (aoss-section),

\section{Fish}

The existence of fish in any stream depends on the quality of all other lactors previously mentionied. II any link is weakened, sooner or later fish poppulations will sulfer. Civen a supply of coot ch
bed materials, fish will spawn

The spawning sites chosen by satmon and lrouk are as different as the habil at they live in. In general, the preferred spawning sines are in riftles or ar the tal ox sides of pools. One not able exception to this is in streams with bedrock or large boudder strean beds whicre the fish tend to spawn in the small paiches of gravel localed on the downstream side of large boxdders. The spawning nesss (redkls) may be reconed as oval depressions in ine graver whan appear bighter or

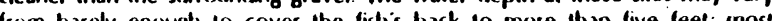

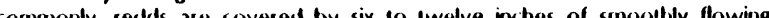
water.
Resident trout prefer to spawn in dean gravel llat ranges in size trom one thalf to $11 / 2$ inches in cliarneler. Salmon and stectleead spawn in gravet that is 1 1h or more inches in diameter. Steelhead, rainbow and aulthroal trout spawn primarily in the months of Aprid and May and their eggs and fry remain in the gravet until mid-summer. Chinook salmon spawn in August and September and their eggs and liy remain in the gravel unit the following spring. Brook trouf. brown trout. Dolly Varden, and kokanee spawn from Sepleinber through December and their eggs and iry also remain in the gravel over winter. Cbvously. he crilkad tine of year lor lish protection win diler by siream. taracteristics, etc Recreational mining causes several problems, not faced by lish managers under normal conditions:

. People wading in streams may discupt spawning activities, causing fish to seek other locations. However, there are only a finited mumber of locations which meet the specific requirements of each kind of fish.

2. Fish eggs or yolk-sac firy can receive physical damage when sucked up by vacumm dredges. This causes mortality.

3. Fine sand and sile deposited over spawning gravels sellles into cracks and may either prevent liesh water from reaching eggs (suffocation), or may physicaly block fry from coming out of the nest.

exists as to possible benefits from mining activities. Two often mentioned are gravet deaning and raising of lish leeding levels through release ceverd questions need to be answered before we can accept these theories

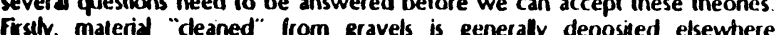
downsiream in the system. Does the deansing - and this normaly includes beneficial malerials as well - of one area outweigh potential harm done to anotherl secondly, food organisms kicked up would provide leeding for only a mined time and area. Would reduced lood levels in dredged area compensate for momentary gainst Sludies in Calfornia seem to show that return of fish and insects to single-pass dredged area may take up to three years. Most streams would coninue to sulfer these damages as long as mining activilies contimue. Research in Caliornia, Oregon, and British Columbia may answer some of these questions. Unti then, fish managers must rely on their best professional

\section{State and Federal Laws}

There are a mumber of laws which gold seekers should be aware of. For more inlormation on any one, you should contact the administering agency.

\section{Washington Department of Game and Washington Department of Fisheries}

Ilyckadics Project Approval (1 PA), issued joinlly by the Departments of Game 75.20.100) $Y$ ous may ored prior to remo 
headquarters. Cold prospecting is divided into three categories:

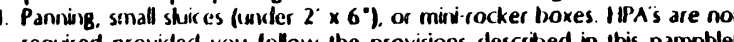
equired provided you lotiow the provisions described in this pamphte

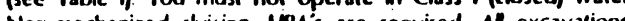

2. Nomechanized slaking. H $\lambda$ s are requined. $A$ II excavalons must be $60^{\circ}$ ong or an ar of $7 \mathrm{~K}$ square the width of the welled perimiter of the stream (see figure 3 and Table You may operate in Class and IN waters only.

3. Mechanized shicing and dredging HiPA's are required. You musi have separale permit for each piece of ecpupment you want lo operale in this calegory. You may operate in Class iv waters only.

\section{Washington Department of Ecology}

Shoreline Management AC

The Shoreline Management Act of 1971 recognizes the value of the states shoreline. both as an inportant natural resource and as an area of sigrificant

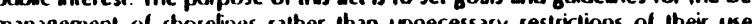
Caties and counties have responsibitity lor locally administering the Act. OH and courity Shoreline Master Programs discuss mining and dredging acivities and promote the wise use of storelines. They include areas where mining and dredging can or cannot be conducled.

Also, they administer a permi system. Any shoreline development, use, or construction activity valued at $\$ 1,000$ or more, or with malerialy interferes with the normal pubic use of the water or shoreline area requires a permil. The Depariment of cology generaly acts in a suppont role to local government. Al gold dredgers are unged to contact thein tocal permit coordinator (usuatly the county p

State Water Quality Standards

As with the Shorefine Management ACl, the State's Water Quality Standards are desinged to protect the nany beneficial uses of our lakes strearns, itvers. and marine waters. Standards do not inctucte activites which. harm benelicial uses. Fur ther, no lessening of water qualiy is allowed in waters in national parks, national recreation areas, national widule refuges, nationat sceric rivers, or areas of national ecological importance.

quality violations. such complaints are true, the depariment can arrest violalors.

\section{Washingtbn Parks and Recreation}

No unauthorized panning or stredging for gold or other precious metals is permited within strearins or other walerways will in the bormdaries of any Stale

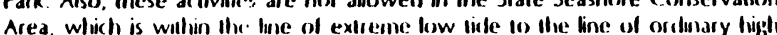

water. This area extends Irom Cape Disappointment to Cape flattery (RCW 3.51.060(7)).

\section{Washington Department of Natural}

\section{Resources}

The right to mine minerals on larrd in Washinglon depends upon the ownership of land. Not all land is automatically "Open." Information regarding "Open" lands may be obstained from Mineral Rights and land Ownership in Resources.

In general, there is no objection to a person examining stale lands to determine which area he might want to lease. However, after an area has been selected, a prospecting lease or mining coniract is required. Prospecting leases are for lwo years. The area covered by a lease may not be less than 40 acres Ness 1 a legal governen bor) or more lhan 640 acres (morell a

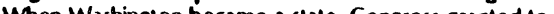

Werctions 16 and 36 there are many surveyed school lands. These lands belong the National forests nol open to prospecting and mining, but may be leased from the State. Even though questions might arise over which lands within the National forests are open to prospecting and mining the prospector wil be faced with lewer problems within the National forests than on most other lands. The lands that are willidrawn from mineral eniry comprise less than 5 percent of the total area of the National foresis of the Siale. The locations of these areas are readily avalable from the U.S. Forest Service.

The beds of non-navigable walers within National forests are open to prospecting and mining. This applies to the minerals on or under the bottom of

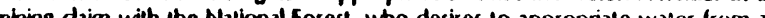
uream or lake within a National forest, must secure a pernit froon the US. forest Service and another from Department of fcology.

Navigalite stream and lake beck within National Forests, regarchess of who owns the strrounding lands, belong to the Slate and are not open to prospecting. Ilowever, they are subject to the mineral leasing laws of the State. Non-navigable siream and lake beds on privale properiy are not open. They must he leased lrom the owner or owner of the land that surrounds the body of water. Naviginle streams and lake beds dre owned by the Slate and are subject to mineral leasing from the State.

tands owned by a cgunly may be feased for prospecting and mining through is couniy rimumissionets.

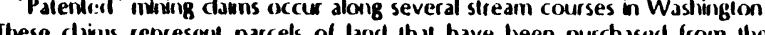
These civer mase them withoul the consent of the owner is lrespassing

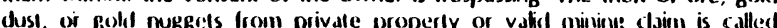

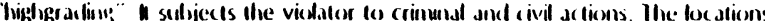


of patented nunng clan'is can be oblained lrom the county assessor tor the Wany where the claim is localed as well as Irom the U.S. Bureau of Land Washing the aldress is

U. S Bureau of Land Management

Spokane Districl Olfice

Spokane, Wasthington
Phone (509) 456-2570

\section{Federal Mining Law of 1872}

This federal law gives prospectors the right to seek gotd on any lederal land in the nation. I does not apply to privately owned or State owned property. on lederal lands, you sill must apply for required state permils.

\section{National Parks}

No prospecting is allowed within the boundaries of National Parks.

\section{Prospecting and Mining Techniques}

Many methods and kinds of equipment are avaitable to the modern gold fish resources can ocrur even it ecripm tis property used Thers, daniages 10 resul mainly from propecting in areas of high sensitivity. These di ativities

\section{TABLE I}

Panning, mini-rocker boxes, and non-mechanized sluice boxes (under $2^{\prime} \times 6^{\circ}$ )

This activity does not require an HPA.

Provision

Resource Protection

All work will be per- Mechanical and/or bigger ecpipment have the formed by hand or hanct capacity to move larger amomits of malerial and look only. have more impart on fishi ile. These aclivities are regidaled by IIPA's issued particidarly for them (see
There will be no disturb- Fish relurn lo specilic dieas to lay their epgis these ance of gravciled spawi- spawning nesis (redils) are found in clean gravcd ing areas (sce discussion from $2 / 1$ inch to 4 inches in dicmeter, depending on under "The Stream Envi- The species Any chsturbance or redhs may cause ronment on how to ahandonment or loss of these valuable reproduc recognize these). live areas Since only certain areas meet the specific requirements of each species, the lish cannot go elsewhere to lay eggs. Consequently, all luture generarions of these lish are also lost 1 prospecting emerge, $100 \%$ morlality normally occurs.

There will be no stream Undercutting streambanks increases instability of bank excavation. These areas. Constant erosion by water, during peak discharge seasons, Nooding. or rany periocts resuths in shimping and eventual loss of plants Siream Environese"

Materials too large to be Large boulders oflen form pools and eddy systems. moved by hand will not These areas provide feeding and resting areas for be disturbed.

Al pits, furrows and pot- Fish may enter the hole during periods of higher holes must be fined and water. If the water kevel later drops, fish are ofien leveled belore comple- Irapped and suffocate from lack of oxygen. Also, tion of each day's opera- other people using the area may fall or otherwise

Any sithation in excess of Cood water quality is essential to maintenance of siale waler Tualily stan- The fisheries resource. Excess silitition can smother dards resilling from this fish eggs, dissupt leeding patterns of young fish project may be consist destroy lood sources, and cover spawning areas ered damaging to lish ile,

causing operalions lo be

cancelled.

\section{TABLE \|}

Non-mechanized sluicing Maximum $18^{\circ}$ wide by $60^{\circ}$

long, or 71/2 sq. It. Not to

exceed 25\% of width of

siream.

Ihis aclivily requires an HPA. A separale

applicalion is necessary for each stream and/or tributary with a different classification. Streams with the same classificalion may be included on the same application. 
All work will be done by Mechanucal or bigger equipment have the capacily quently, may impact rest aclivities are regudated under special HiPA.

There will be no disturb. Fish reltun to specilic areas to lay their eggs. These ance of graveled spawir- spawning nesis (redc(s) are found in dean gravel

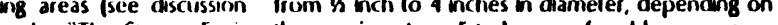
under the Sirean thut the species. Any disturbance of redds may cause ronment" on how to abandonment or loss of these valuable reproduc-
recognize these). tive areas. Since only cerlain areas meel the specific requirements of each species, the fish cannol go generations of these fish are also lost. If prospecing occurs when egess are in the redds or pust aller fry emerge. $100 \%$ mortality normally occurs.
There will be no strean-

Undercusting streambanks increases instability of these areas. Constanc erosion by water during peak discharge seasons. flooding, or rainy periods results in shmping and eventual loss of plants. Mnportance Environmen

A puls, flurrows, and fish may enter the hole dering perioxk of higher potholes imust be inted water. Ir the waler levet tater dops, fish are often and leveled before con- Irapped and suifocale from lack of oxyen. Also, pletion of each day's other people ush g the area may fal or otherwise operation. injure themselves by slepping inuo these holes.

No darming or chiver- Any changes in mormal stream flow can cliy isp sions of the flowing downstreanin seginents, block normal fish passsage. stream will be alloweil. or dissupt feerfing areas.

indess specifically allowed
Material too large to be Large boutcers often form pools and eddy systems. moved by hand will not the fish

Activinies contrbuting 10 Siltation can smother eggs in the immediate area excess siltation shoudd be and downstream as well. Also, silt interferes with avoided.

- leeding patterns of young fish.

\section{TABIE III}

Mechanized sluicing and dredging.

Maximum size of sluicing box

$18^{\circ}$ wide by $60^{\circ}$ long, or 71/2

sq. ft. Not to exceed $25 \%$ of

width of stream.

This activily requires an HPA for each piece of equipment which will be used. A separate application is necessary for each stream and/or tributary with a different classification. Streams with the same classification may be included on the same application.
Provision

There will be no stream bank excavation

\section{There wit be no disturb- ance of gravelled spawir incler the Stream fonvironmenti" on how to recognize (liese).}

\section{Resounce Prolection}

Underculting streambanks increases instability of these areas. Constant erosion by water during peak in shemping and eventual loss of plants. Importunce of these areas is discussed under "The Sirean Environment"

Fish return to specific areas to lay their egas. These spawning nesls (reckes) are found in dean gravel rom 3 hech lo a minches in diameter, depending on The species. Any disturbance of redds may cause ive areas Since only certain areas meet the specilic ive areas. Shice of each species, the fish cannecil elsewhere to lay eges. Consecuently, all future generations of these fist are also kest If prospecting occus when eggrs are in the recklds of pust after firy emerge. 100)', mortality normally occurs. 
All pits. lurrows, and Fish may enter the hole during periods of higher potholes must be filled water. If the water level later drops, fish are often and leveled before cont Irapped and sullocate from lack of oxygen. Also. other people using the area may fall or otherwise
injure themselves by stepping ino these holes.

No damming or diver- Any changes in normal stream flow can diy up slons of the flowing downstream segments. block normal lish passage. stream will be allowed or dissupt leeding areas.

unless specilically allowed

No tracked or wheeled Sigrificant damages occur to the streambed when eter of the stream.

Materials too large to be Large boutders often form pools and eddy systems. moved by hand will not These areas provide feeding and resting areas for moved by hand
be disturbed.

Extreme care will be Gasoline, oil, and other hazardous substances can Iaken to assure no gaso- cause instant death in aquatic organisms. may we, oil, or other harmild lake many moniths for traces of these materials lo material is allowed to fall, be washed from the system.

be wasted into, or other

Any sillation in excess of Cood water quality is essential to maintenance of state water quality stan- the fisheries resource. Excess sithation can smother
dards resulting from this fish eggs, discupt feeding palterns of young fish, project may be consid. destory lood sources, and cover spawning areas. ered damaging to fish bife. lerminated and the IPA

cancelled

\section{Stream Classifications}

Slate waters have been dassified by lield biologists using the following ACTivity

CASS 1 - Total Protibition of Panning, Shicing and Dredging

CAAss - Panning Only

- CLASS 1 - Non-motorized Shicing

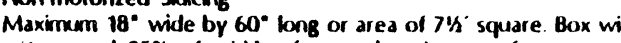

- CAASS IV - Motorized Shicing/Dredging

- A Class or $N$ activity inctudes al lower class activities as wel. Untess pedificaly stated otherwise, timing for Class 1 will be the same as Class $N$, a

THUNG

1. Ny twrough Odober ONeY

2. The through September ONMY

3. August through Seplember ONer

1. Mry twough August Onar

5.

6. August itrougg
7. Year-around

A. $2^{*}$ nozzle and hose maximum allowable

. 1" mozile and hose maximum allowable

C. 6: nozkle and hose maximum allowatle

Exampits. Class 4 - Paming Ondy - Ndy through August

Class It - Paming Ondy Sthicing - vear-around

Class N 68 - Motorized Shicing/Dredging - August through

$\|$ a water is nol fisted, applications will be considered on a case -by-case basis. In order 10 avoid sthmitting an application that may be denied. you shoutd

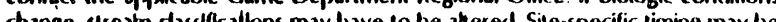
necessary th special comativis 


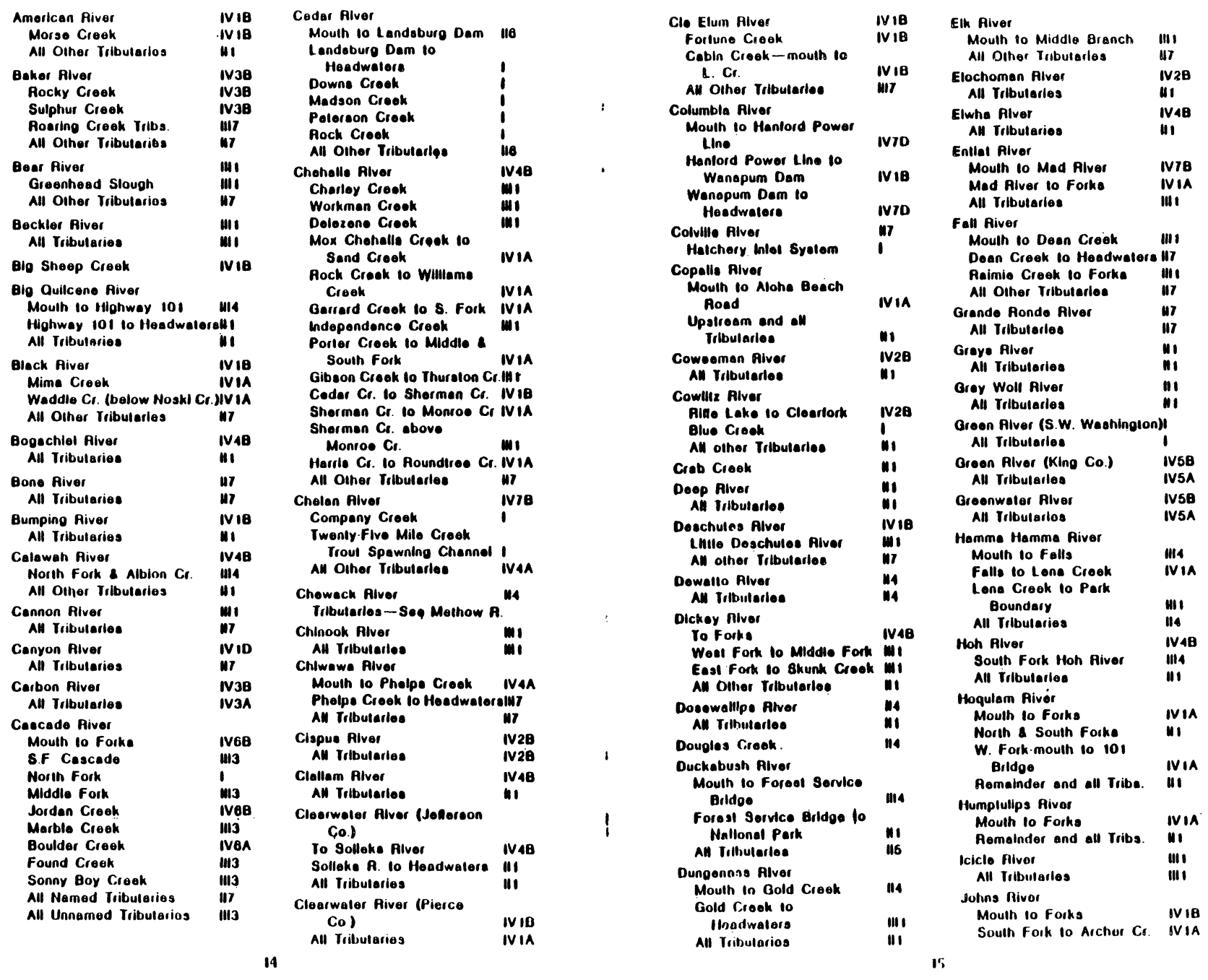




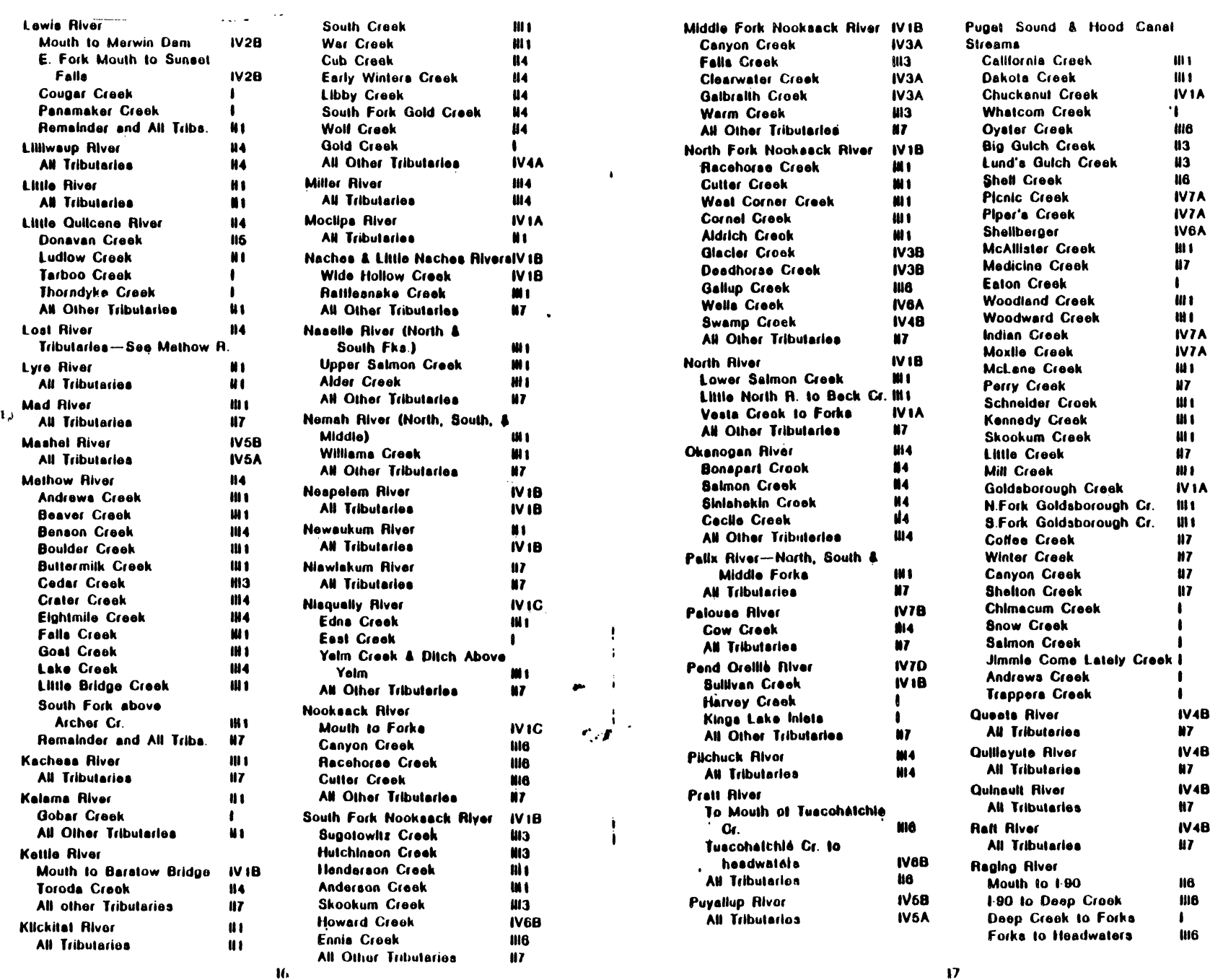




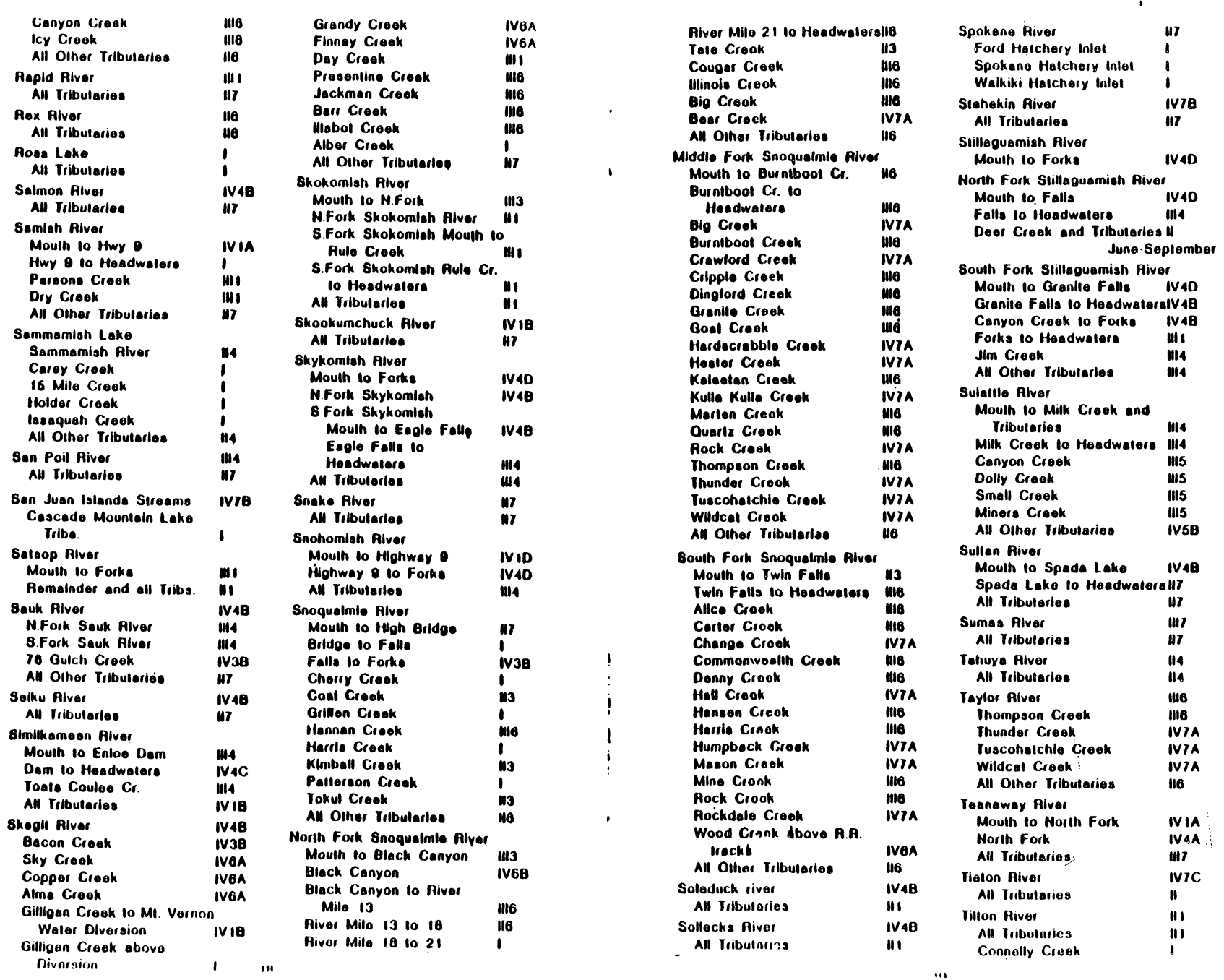




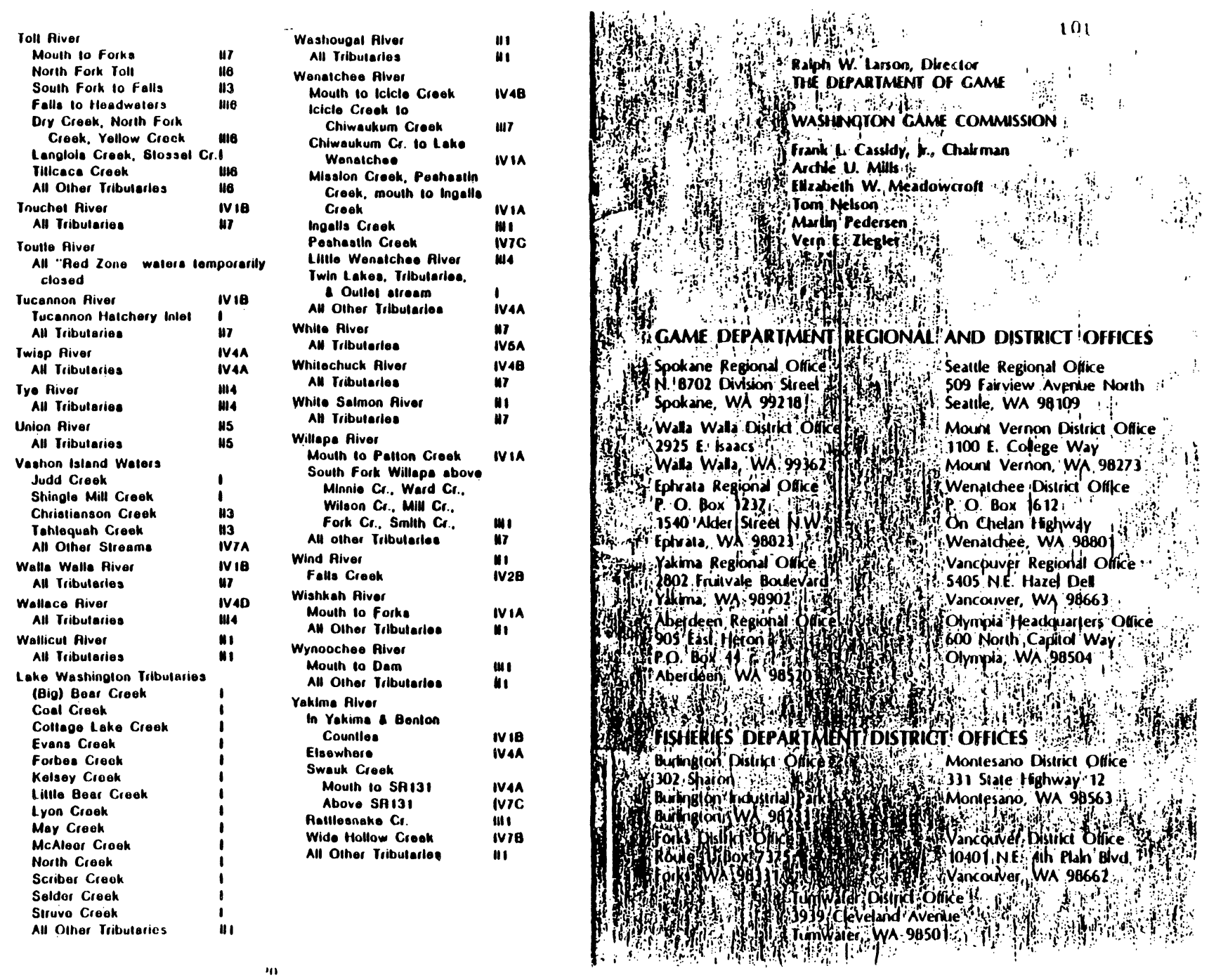

